\title{
, وا.
}

دور5 بيست وجهارم

عشقو نا بودى دررنتينكمانلاورنس از: مرضية سهبعى درنى

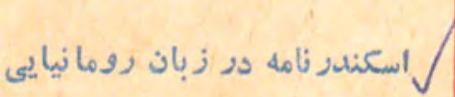
از : ويورل بأجاكو رونانيان

سيرى در أدبيات معاصر 31'ين

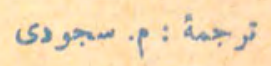

از: مسمود فرزان

ترجمة : صفدر تقىزاده

باران و اشك

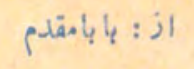

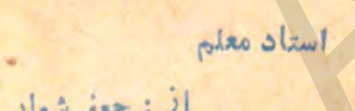

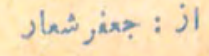

به همبر اه اشعارى ازئ

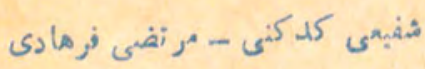

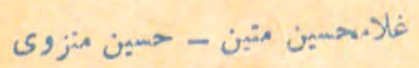

فريدون مشيرى - نادر نادريود

وتز ارش هائ ماه ....... 


\section{ف}

هraiv

rYq

rro

rYV

rov

rvi

rVV

rAq

rag
jI

عنوان

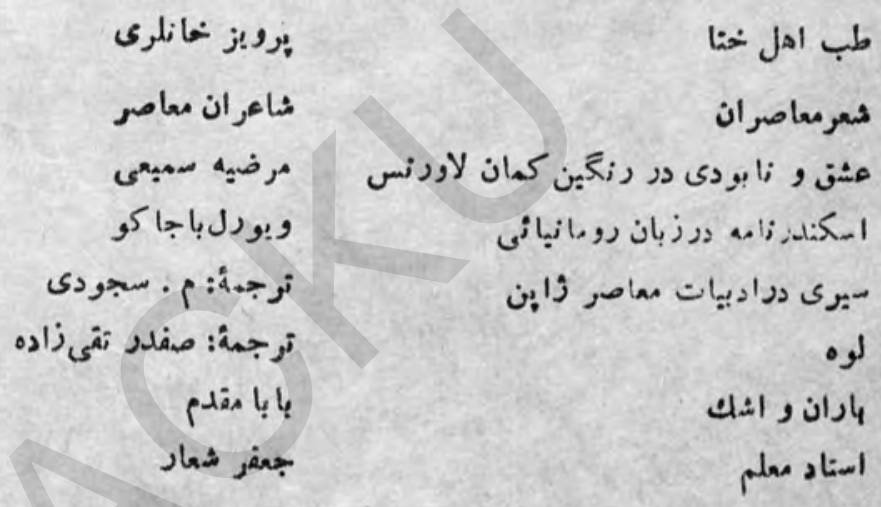

سخن وخوا نند

pas

درجهان دانش وهنر

$p \cdot q-p$.

تأن

PI -P.Y

حيثتشيشاكتا بفروشى

PIP-PIF 

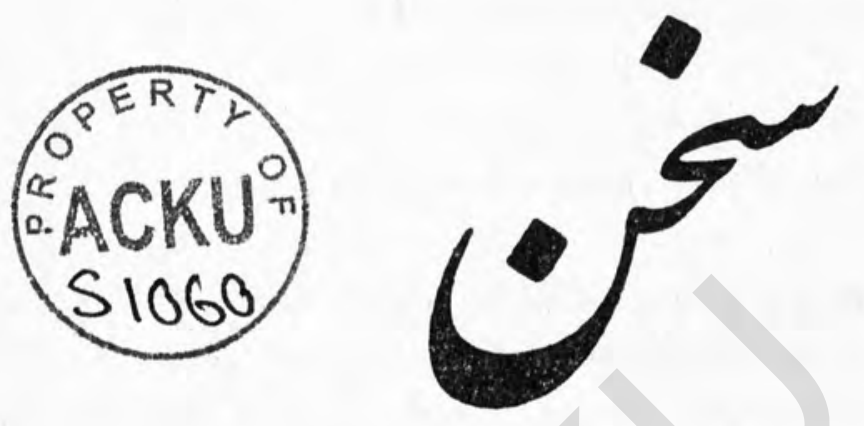

شمارة جهوارم

دورة بيست وجههارم

فروددين

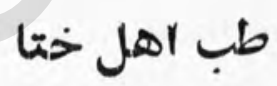

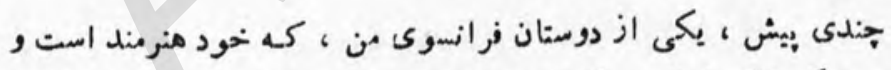

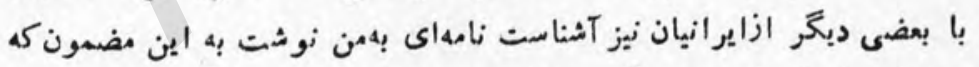

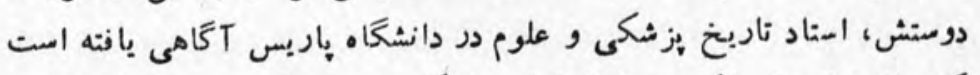

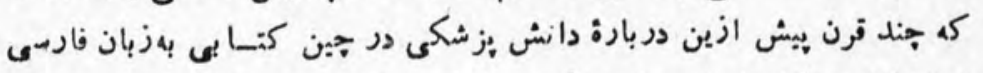

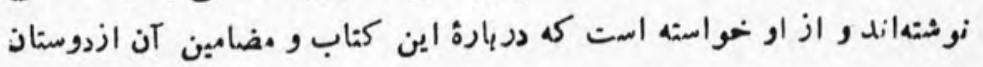

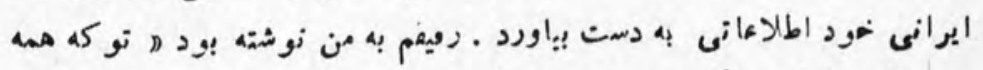

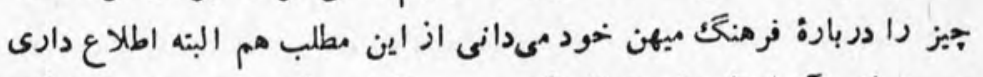

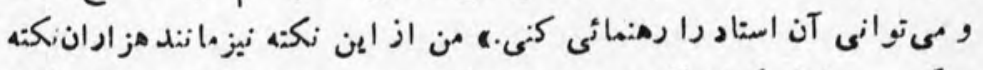

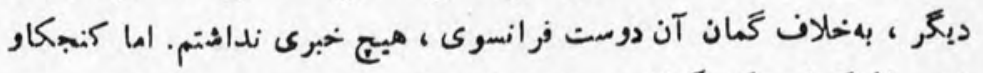

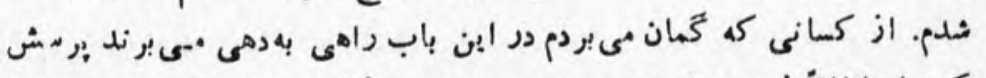

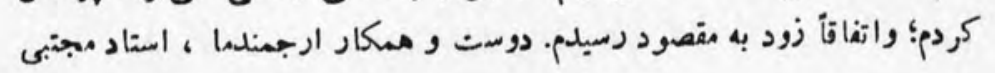


سخ نو دورك

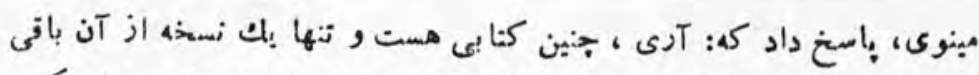

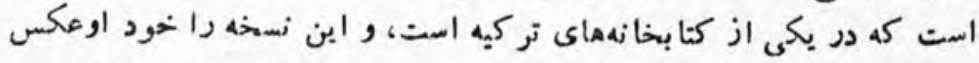

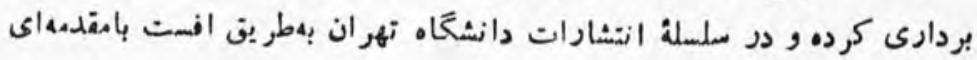

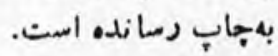
من كتاب را نديده بودم. جند نسهه ازان براى من فرستاد كه زوديكى

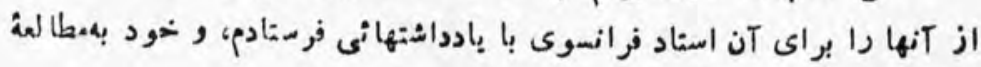
كتاب هرداختم.

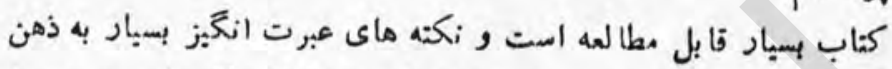

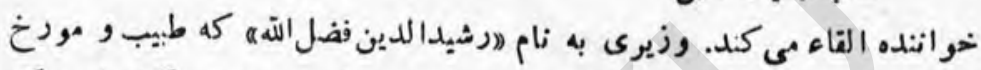

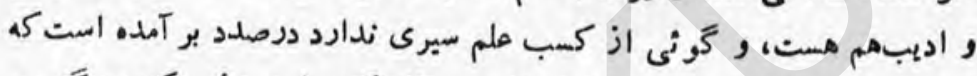

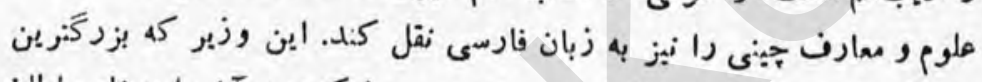

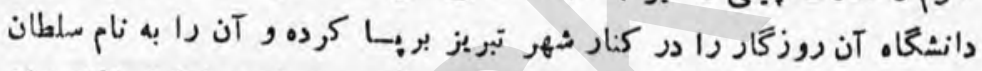

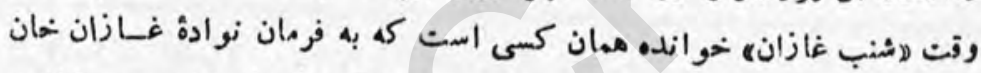

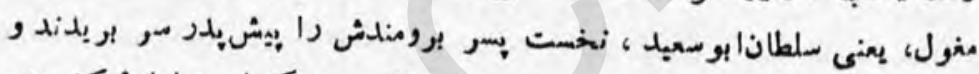

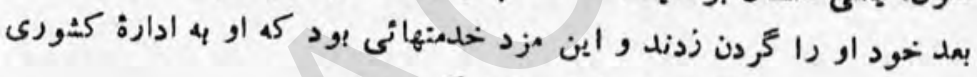

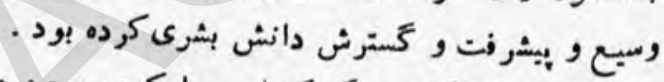

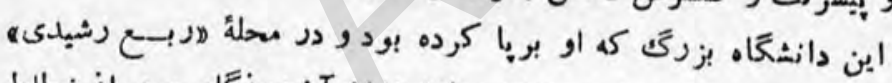

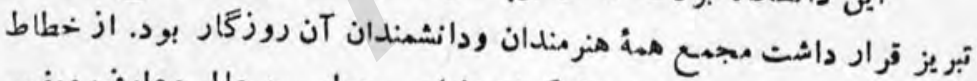

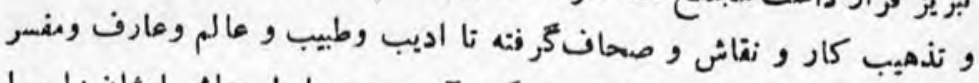

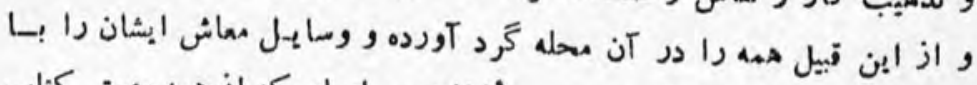

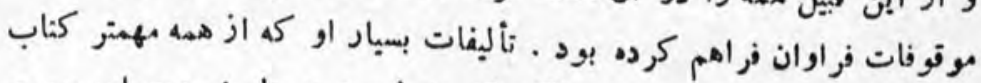

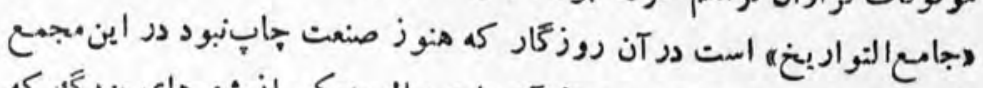

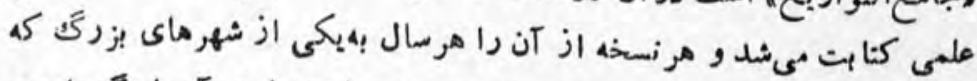

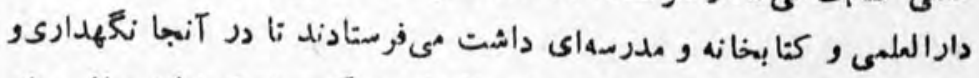

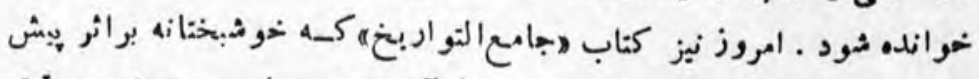

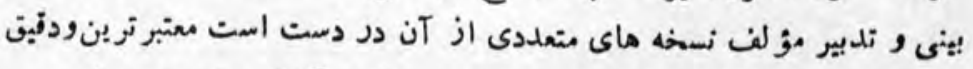

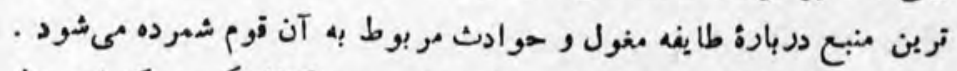

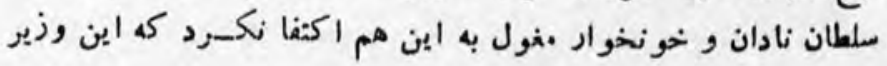




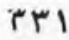

دانشمند و لايق را با همه نسل وتبارث زاب بود كثد: فرمان داد كه هشنب غازانه

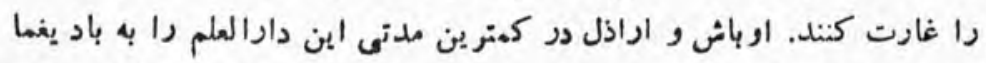

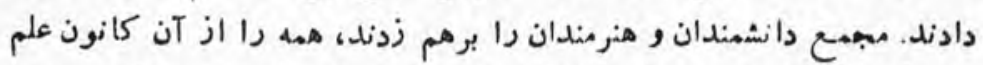

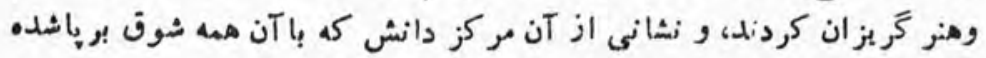
بود ارجا زيخذاشتند . حاصل يك عمر كوشس وزيرى دانشمنل براى تسرويج

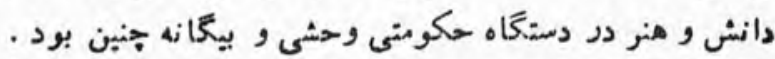

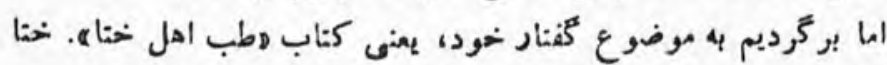

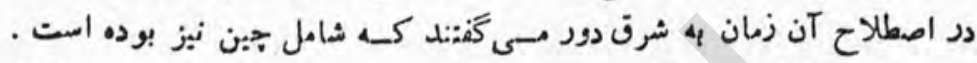
رشيدالدين فضل الله دريافته بود كه جينيان در بعضهى از علوم تخدصع دور دارند

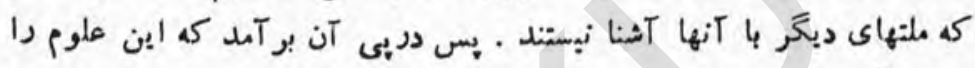

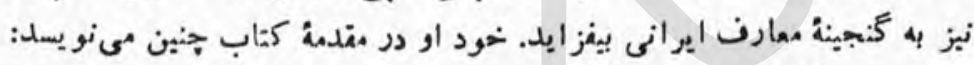
هدر آن شك أيست كه كتب اهل مغرب و اين هما لك، و كتب الب افرنج

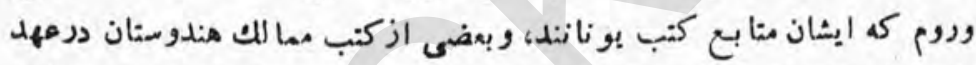

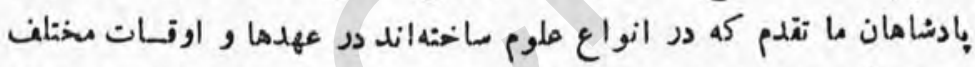

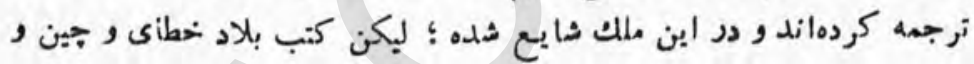

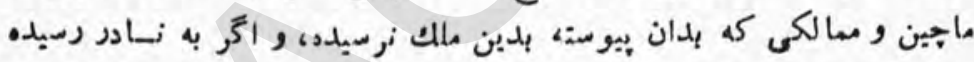

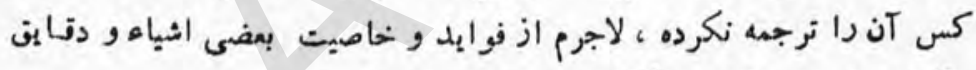

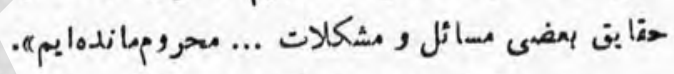

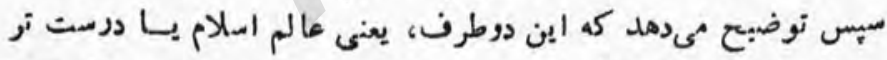

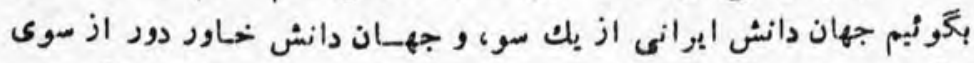

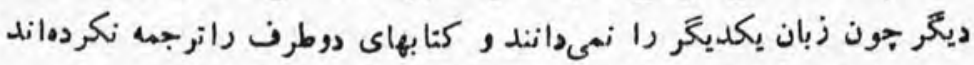
دانش طرف ديگر را باور ندارند و انكار مى كنيد. اين وزير و مورخ كه تخصص او در مزثكى است درصددآن بـر آمده.

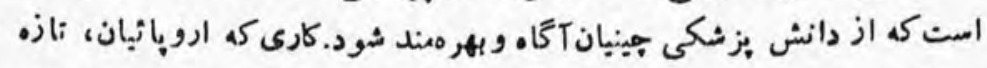

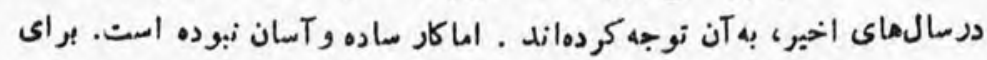

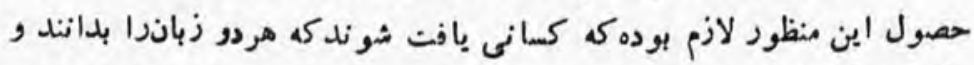

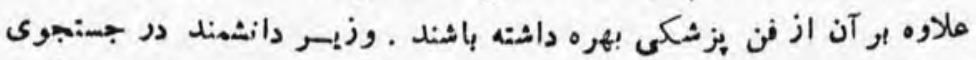

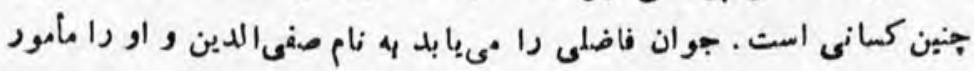


سحن- دورל مe

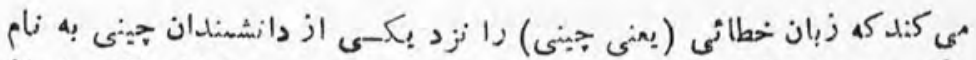

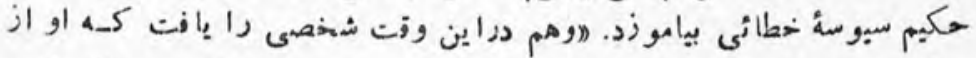

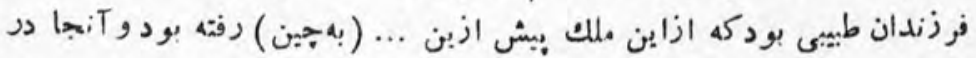

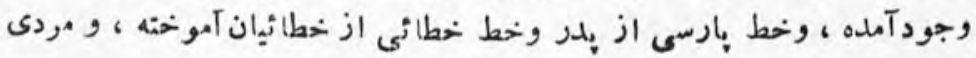

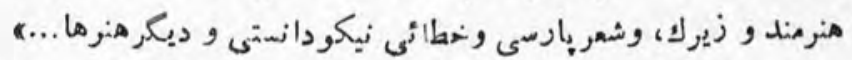

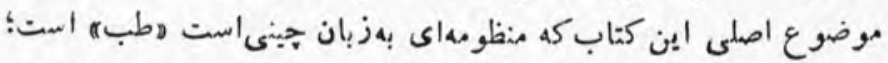

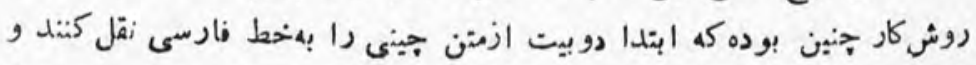

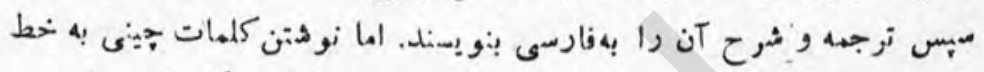

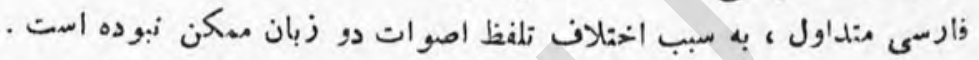

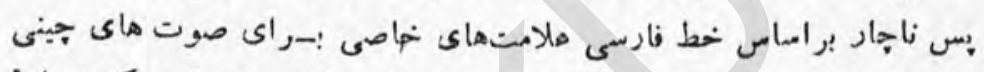

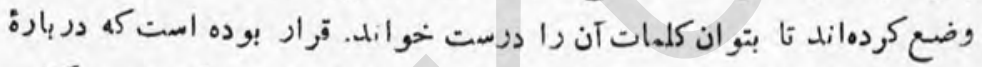

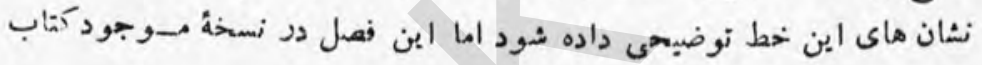
دإلده نمى نشود.

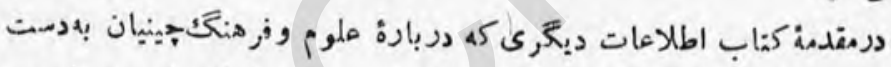

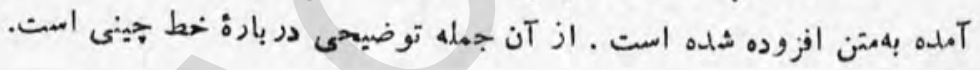

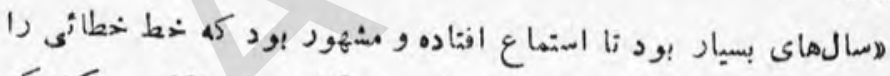

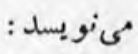

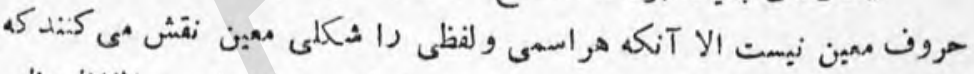

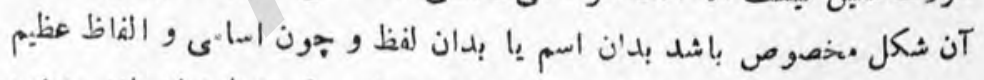

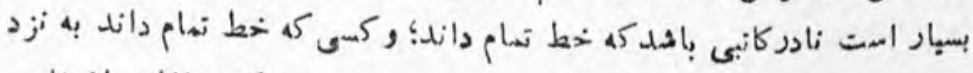

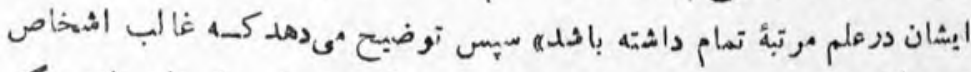

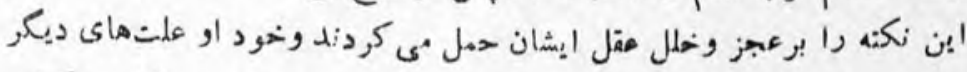

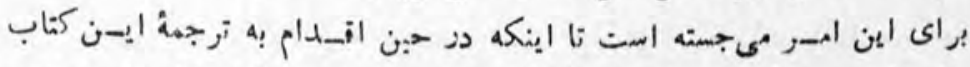

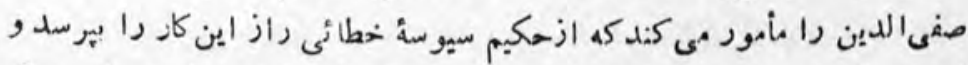

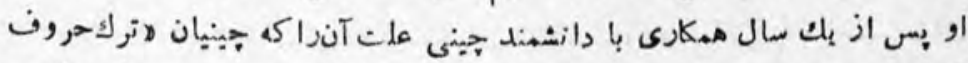

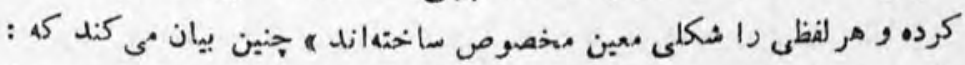

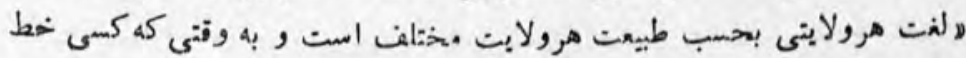

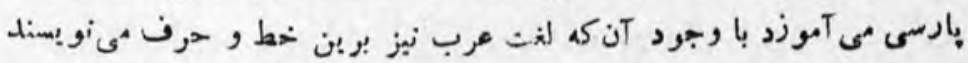




\section{rrp}

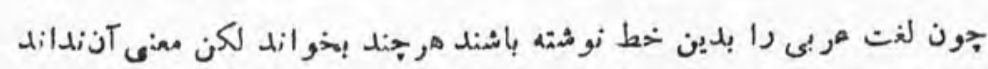

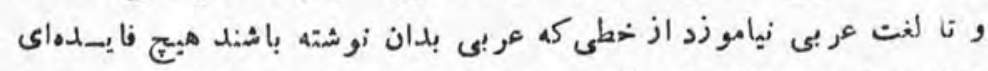

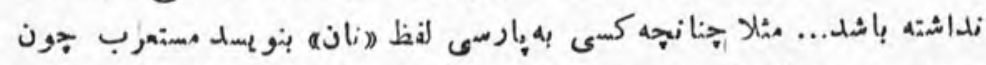

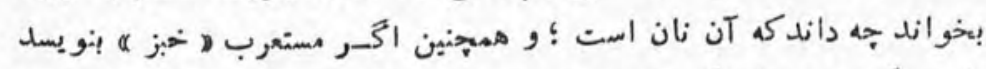

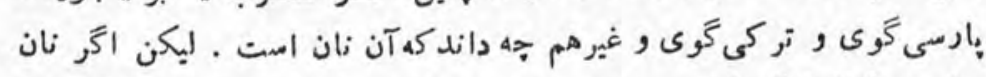

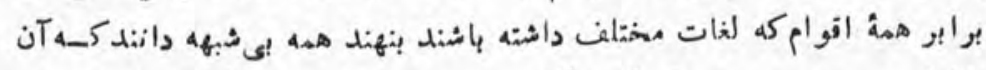

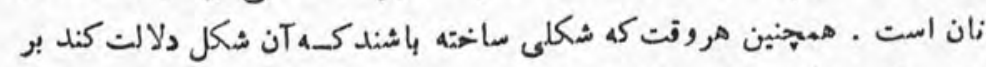

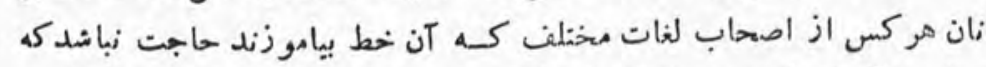

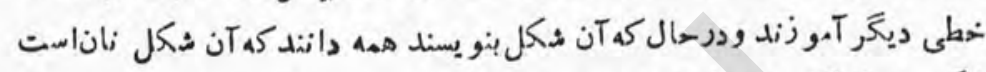

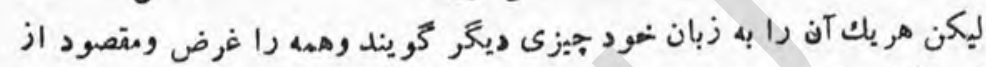

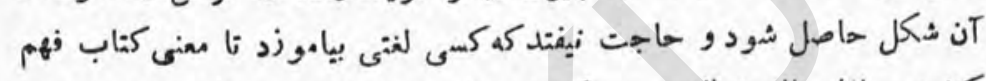

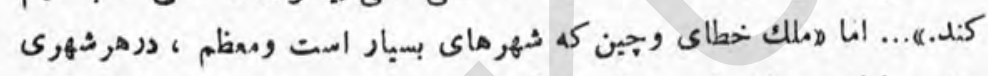

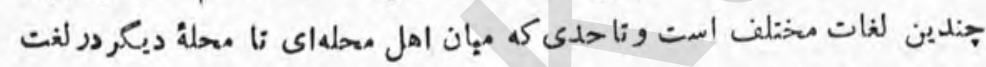

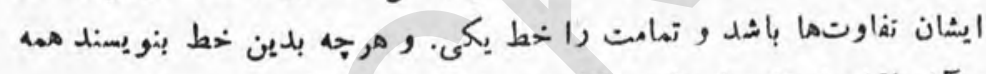

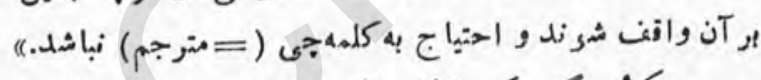

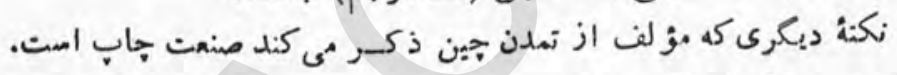

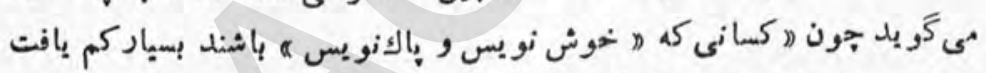

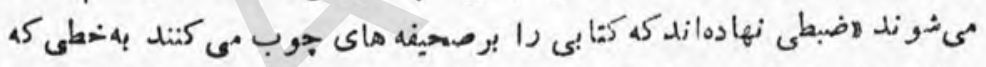

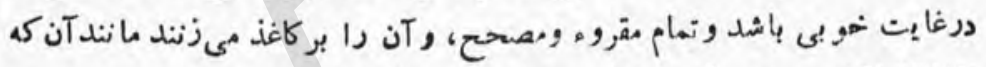

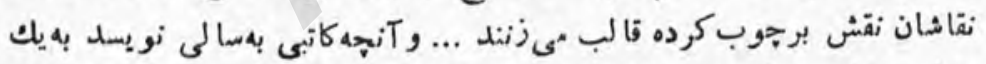

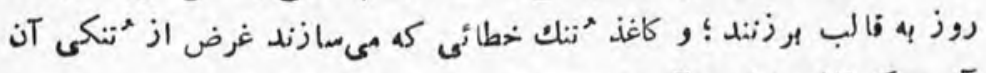

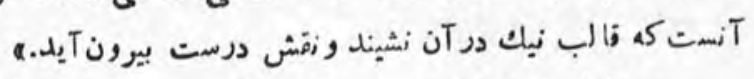

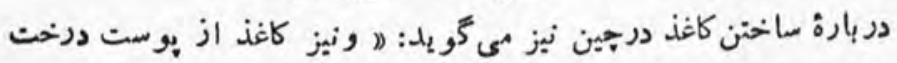

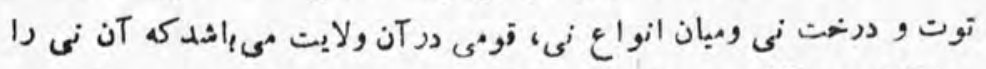

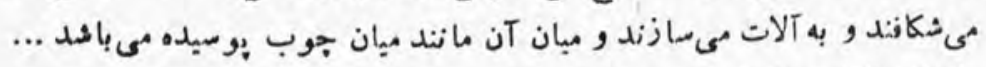

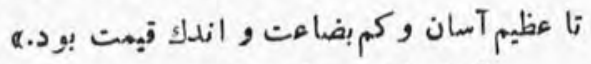

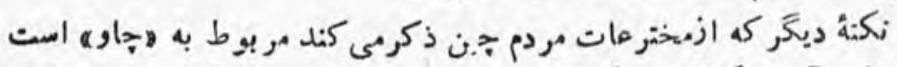

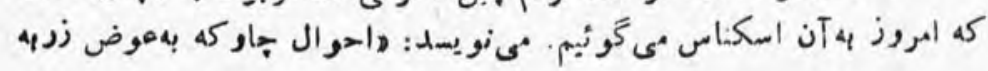


سخن - دور ريb

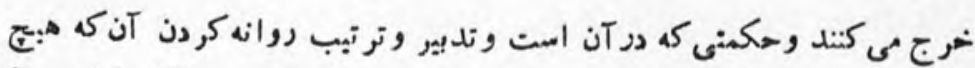

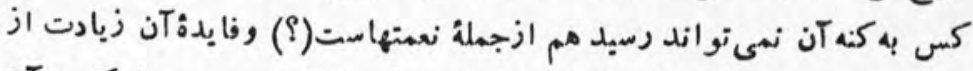

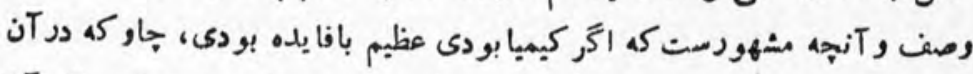

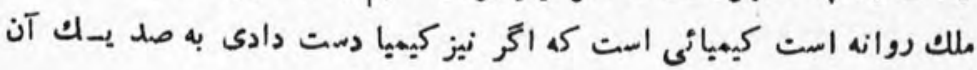
نرسبدىه

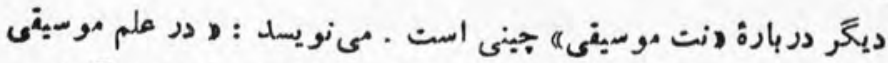

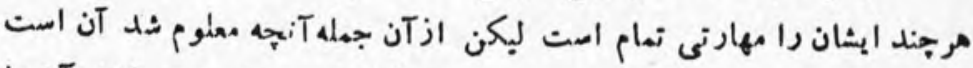

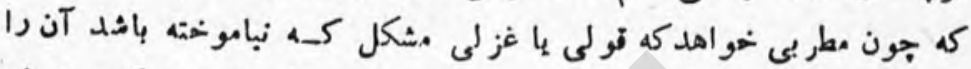

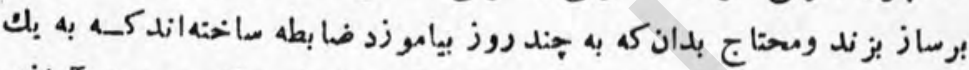

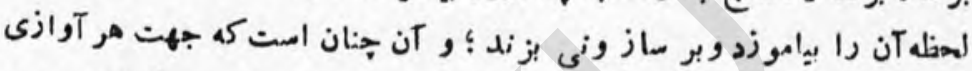

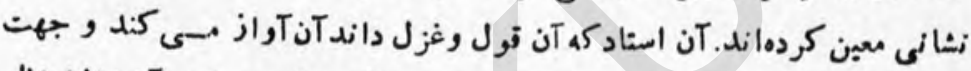

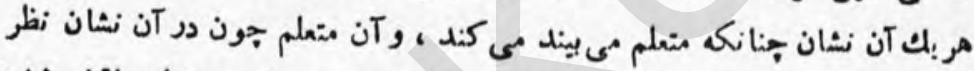

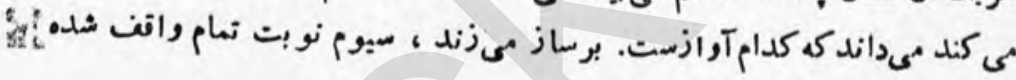

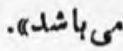

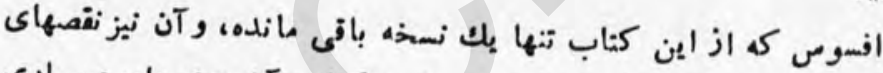

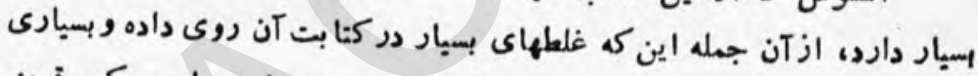

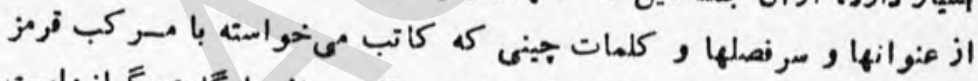

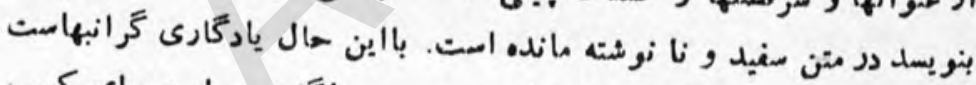

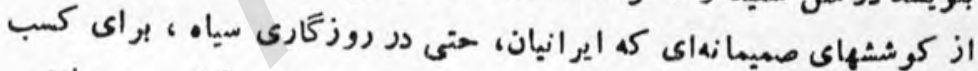

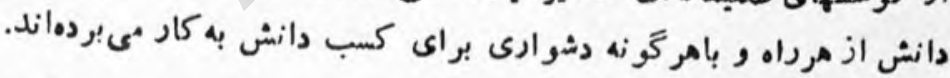
يوويز ناترخانلرى 


\section{سرودى بر اى شهر كو حكمان}

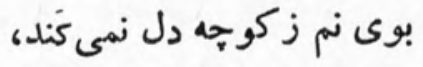

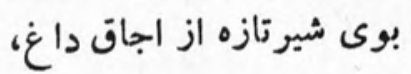

$$
\begin{aligned}
& \text { بوى نان شاته از تنوركرمب، } \\
& \text { عطر سرد بونه ازخلموص آب. } \\
& \text { 울 } \\
& \text { ذهن من ز ياد كوجهماى شهرمان تهى نمى شودة، } \\
& \text { ذهن كوجه ازعبور عابر ان: }
\end{aligned}
$$

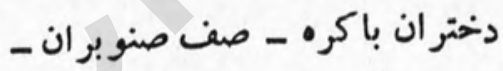

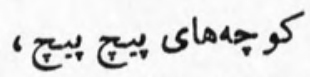

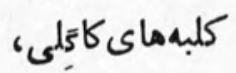

$$
\begin{aligned}
& \text { بيدهاى مهر بان، } \\
& \text { سام ! مان } \\
& \text { ذهن سبز من } \\
& \text { زجويبار يادتان } \\
& \text { جدا مباد! }
\end{aligned}
$$

مر تضى فرهادى 
ابرى ثر هدصار

$$
\begin{aligned}
& \text { من درجصار كو هاك خود، مثل ابرها } \\
& \text { • برواز ميكنم } \\
& \text { من درحصار كوحجك خود، مثل ابرها... } \\
& \text { شب، آن زمانكه تيرگَى زرف دردناك }
\end{aligned}
$$

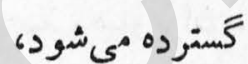

$$
\begin{aligned}
& \text { هىايستم بهزوى زمين، بربسيط خاك }
\end{aligned}
$$

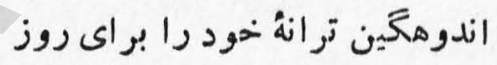

$$
\begin{aligned}
& \text { Tغاز مى كنم. } \\
& \text { اندوهكين ترانهُ خودر ا بر اي روز ... } \\
& \text { 중 } \\
& \text { قلبم هوزندهاى است } \\
& \text { در آسمان اين شب سرد بر زلهه سوز.... }
\end{aligned}
$$$$
\text { تهران - تلان }
$$$$
\text { غلامحسين متتين }
$$ 


\section{غزل هه}

برق سيهيده ديدم در مشرق جبينت كل ها بهديده هجيدم از باغ آستينت در اوج خويش جو نان خورشيد نيمروزى

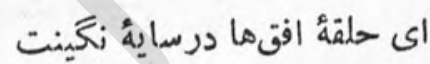
شير ين و مهر بانى، شير از دخترانى تلفيق عشق وشعرى ، مانند سرزمينت تصني جون باده مى تراود ازكوزهاى نگمارين شعرى كه مى تر اود از جشمى ناز نينت

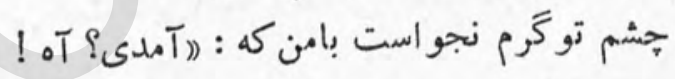

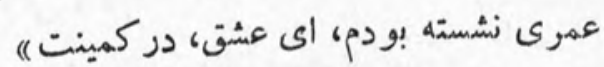
با خو اهش نيازم دار ند ماجر اها

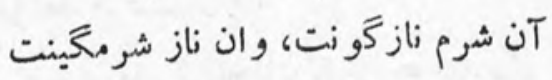
ازجادة فلقها بر اسب روشنائى

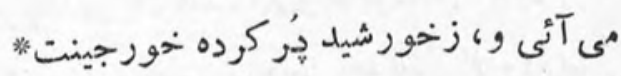
آرى تو آن صدائى ، ايى آشنا ! كه بإيد تا جاودان بِيبحد درهستى ام طنينت.

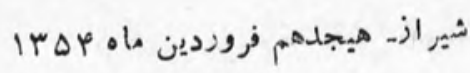

\section{حسين منزووى}

*- خورجين، بروزن دور بين تلفظ شود. (نكاه كنيد به، فرهنك دمين). 


\section{تصويو ديَو}

به : شبنم جام جم

$$
\begin{aligned}
& \text { گرحهه نرگس نيستم تا در زلال بركة ساكن } \\
& \text { ـ يا دراب جشمه جارى - }
\end{aligned}
$$

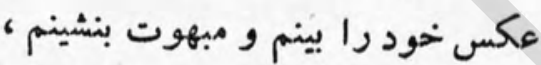

$$
\begin{aligned}
& \text { ليك، خود را بيش ازو بازيجة آئينه مى بينم } \\
& \text { صبح امروز اين حقيقت را مسلنم بافتم، آرى : }
\end{aligned}
$$

$$
\text { خيره در تصوير خود بودم }
$$

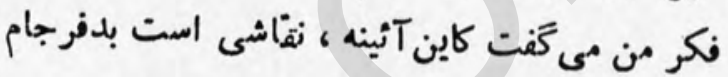

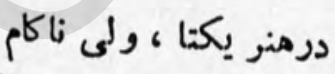

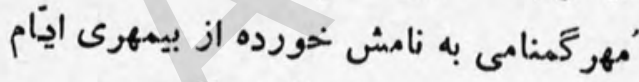

$$
\text { انتقاهش رازما خور اهد كرفت آرارام : }
$$

با قلمموى زمان، تصوير ما را آنجهنان تغيير خو اهد داد كزجوانى ^رجه در ياد است، ويرانَّردد از 'بنياد.

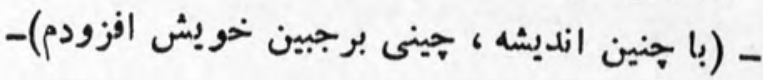

\section{-}

T ، هايد در ضمير صاف آثينه

$$
\begin{aligned}
& \text { نركسى بودم كه نقش خويش را برآب مى بيند } \\
& \text { ياكهنسالى كه تمثال عزيز نوجوانى را بورا } \\
& \text { وازَّون در قاب مى بيند. }
\end{aligned}
$$


(2)

$$
\begin{aligned}
& \text { ناكُانان در بِر كُ شفَاف آئينه } \\
& \text { جشمهاى آشو بكر, جومشيد : }
\end{aligned}
$$

عكس من صد هاره شد، هرياره را موجى فرويوشيد.

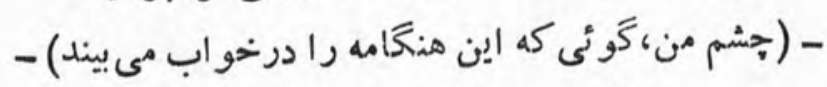

6

6

يارهاى عاى عس من ظاهرشد از اطر اف آئينه

جمع شل ، تصوير ديكر 'شد :

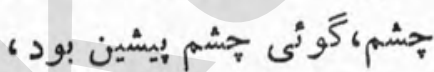

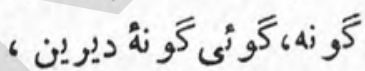

ليك درتر كيب، باتصوير اول نابرابو شد شهد

$$
\begin{aligned}
& \text { - (هر جه در بيكان (ه) كو شيد، } \\
& \text { با من ازاو آشناتر شل) - }
\end{aligned}
$$

\section{6}

من در آن تصويرك سيمائى نجيب و ناز نين ديدم

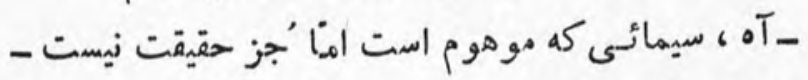
در دل جشهمش، هزار ان جشم شو خ شرمئين ديدم

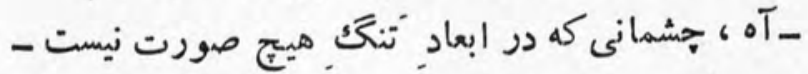
من در آن تصوير، , ههر وكينه را با هم قرين ديدم

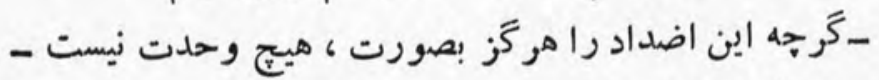
من درآن آئينهُ روشن صبحكاهان، اينهيخين ديدم. 


$$
\begin{aligned}
& \text { ليكن اكنون، شامكاهان است } \\
& \text { بـر كة آئينه، همبحون صبح، رَخشان است } \\
& \text { هيج آشوبى در اعماقش نمىرويَد }
\end{aligned}
$$

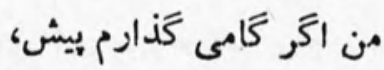

$$
\begin{aligned}
& \text { عكس 'رخسارم درآفاق زلالش بازخو اهله تافت } \\
& \text { ليك بامن، آن ضمير خفتهُ بيدار، مى گويد: }
\end{aligned}
$$

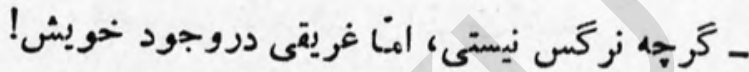

$$
\begin{aligned}
& \text { جشمهاى بايٍ كه در آئينه يا درمينهات جوشل } \\
& \text { جشمهاى بايد كه موجش عكس رويت را فرو هوشد } \\
& \text { تا بهجاى نحويش، آن سيماى باك مرتوافشان را توانى يافت. }
\end{aligned}
$$

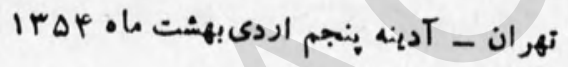

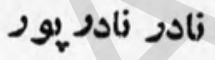




\section{عشي و نابودى مدر}

\section{( ( ) (2)}

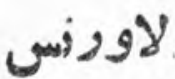

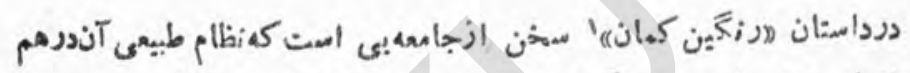

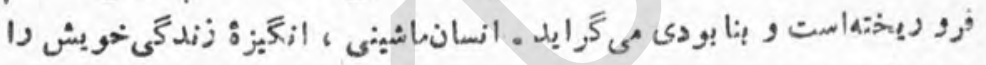

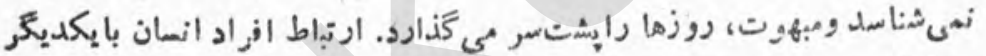

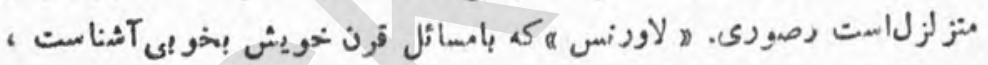

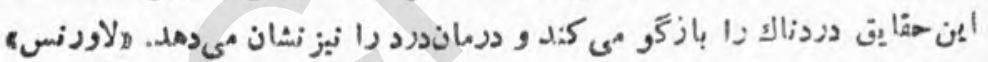

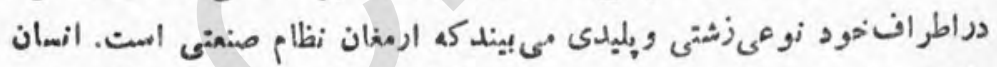

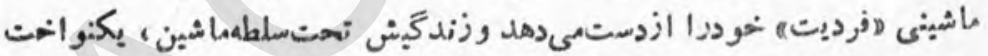

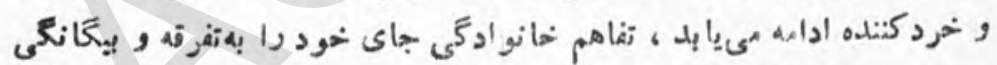

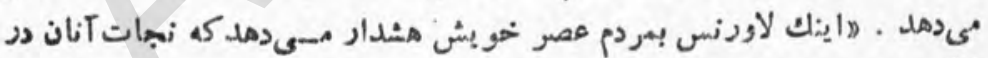

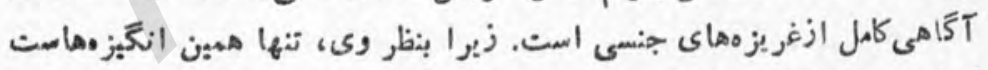

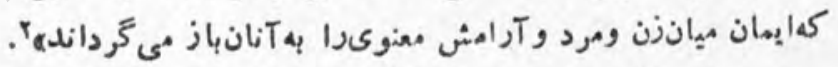

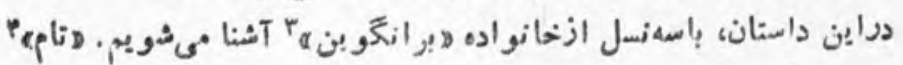

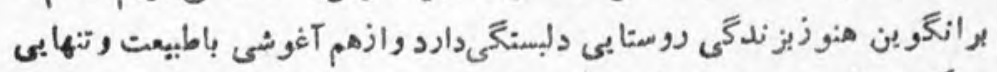

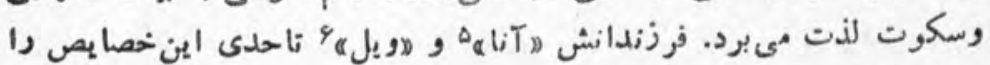

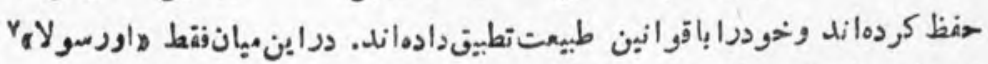

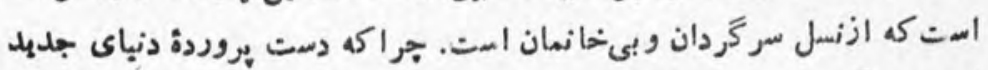

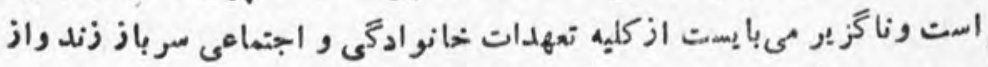

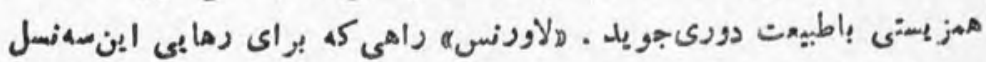

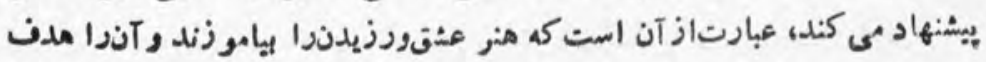




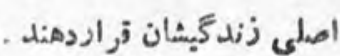

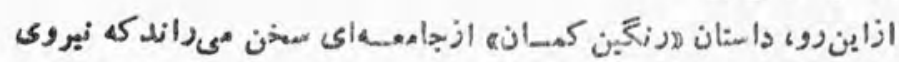

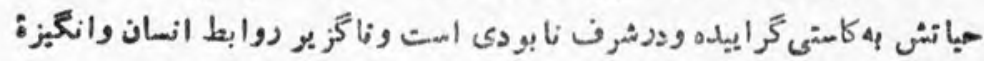

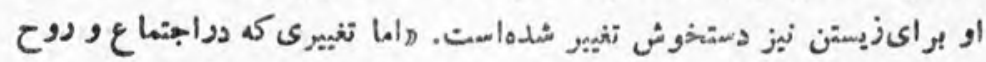

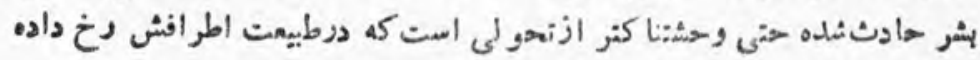

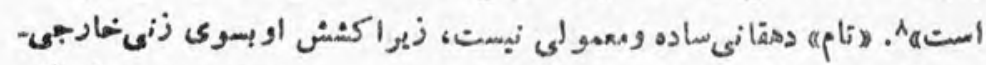

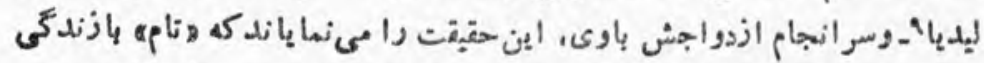

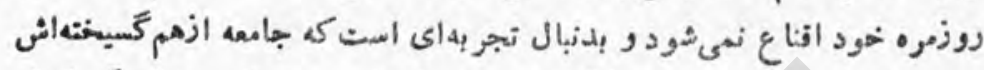

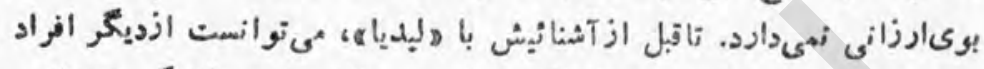

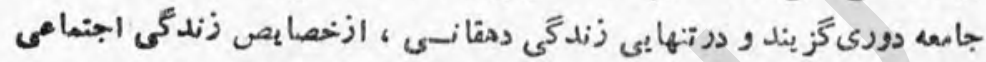

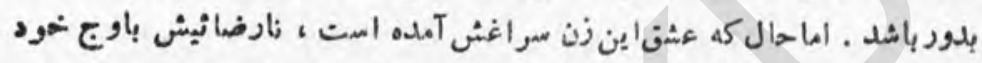

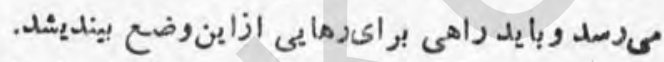
مرخورد

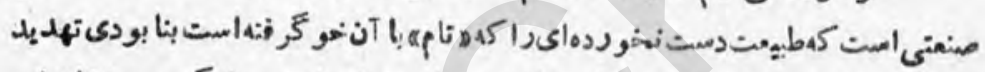

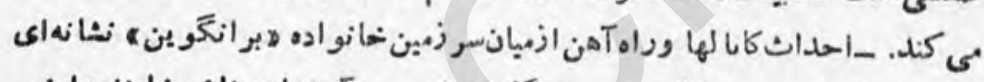

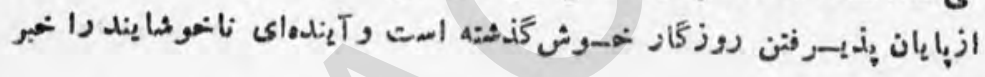

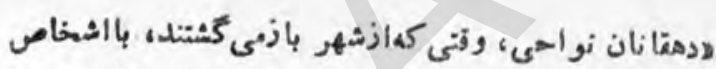
:

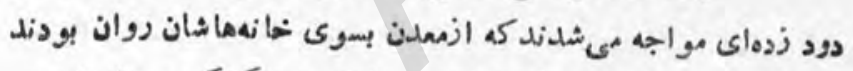

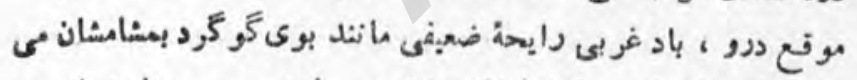

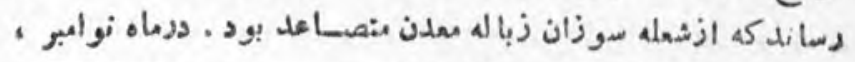

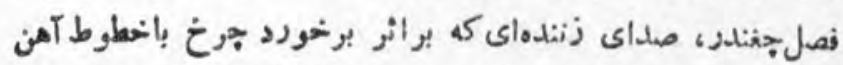

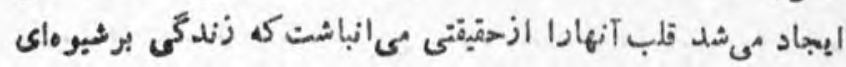

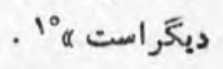

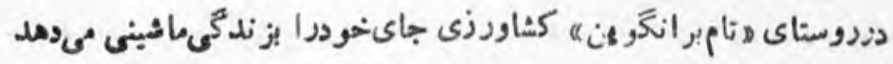

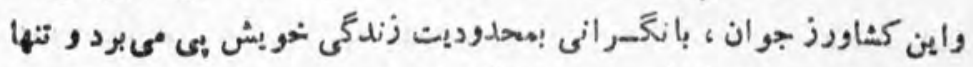

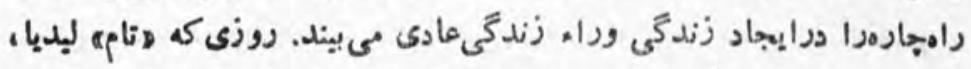
رامى بيند، درهىيا بدكه تنها راهنجاتش ، عثنىورزبدن با آن زناست و ازدواج 
YYV

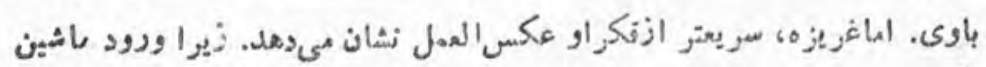

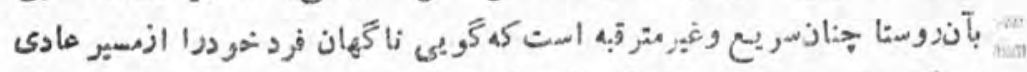

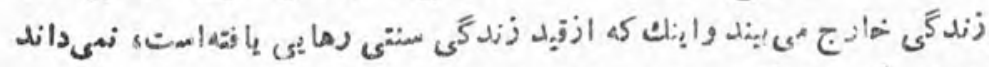

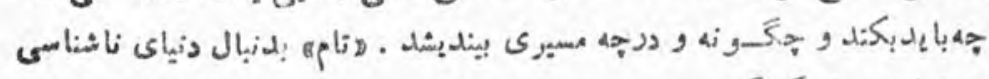

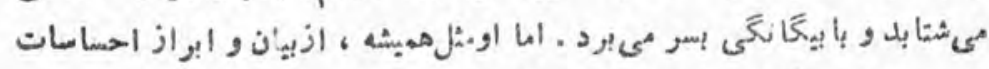

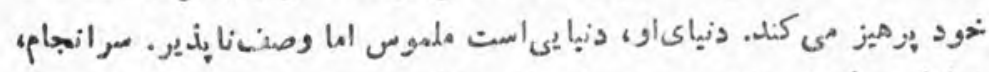

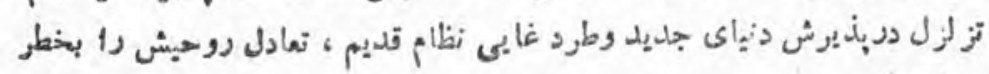

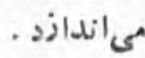

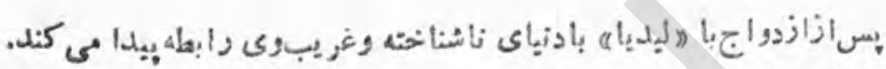

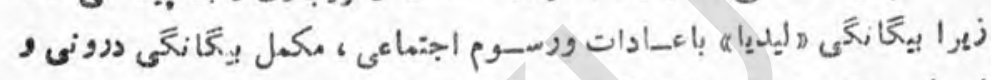

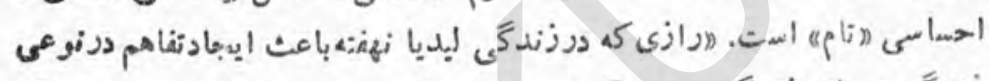

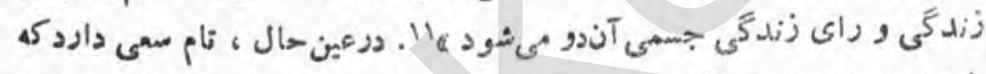

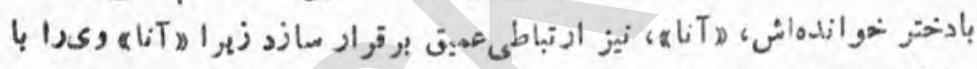

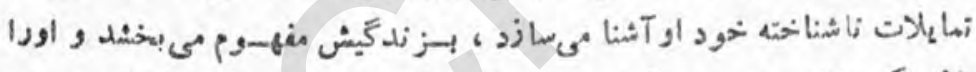

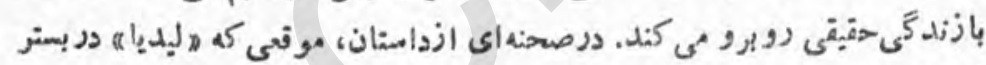

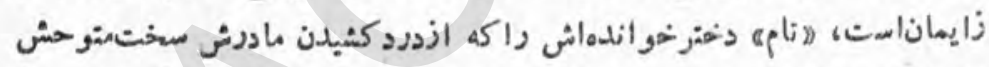

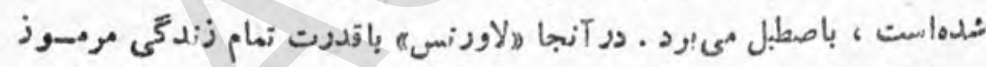

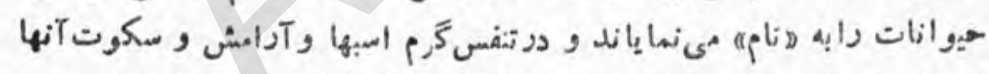

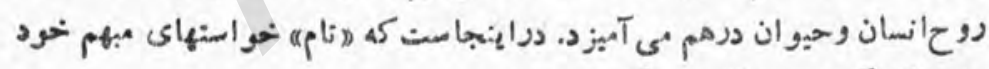

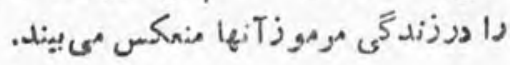

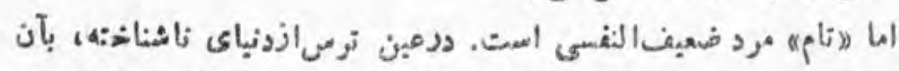

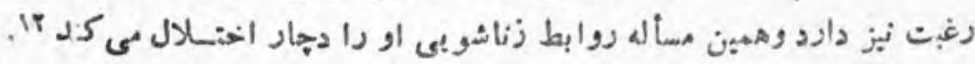

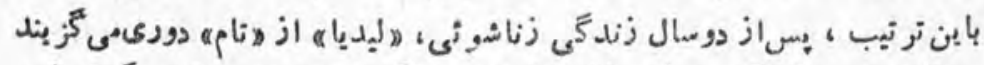

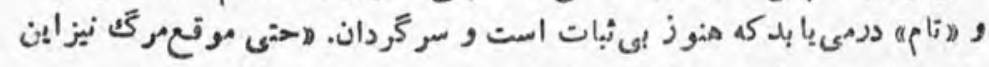

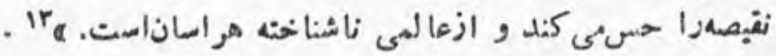

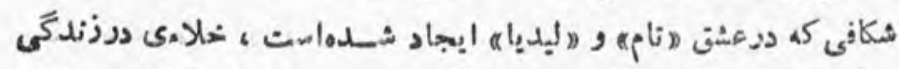

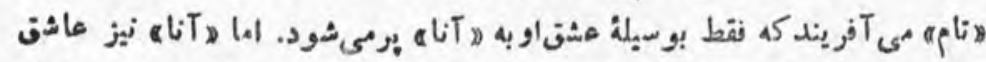

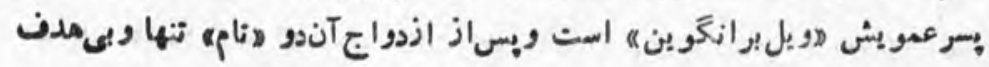


rebs - سي rYA

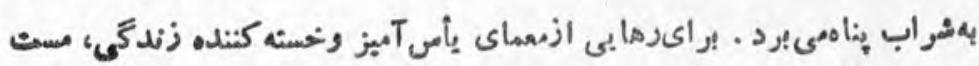

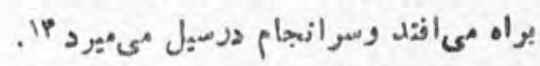

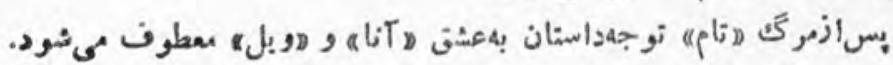

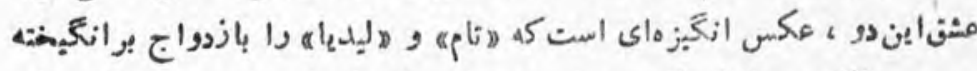

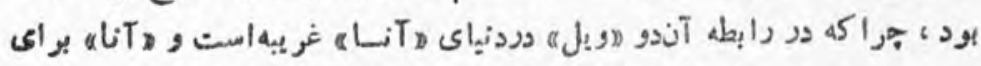

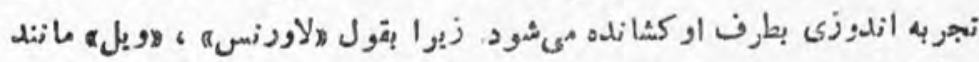

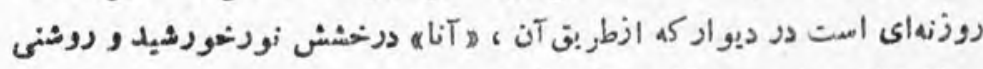

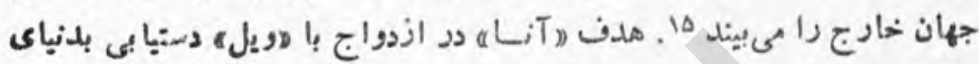

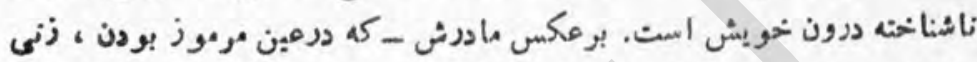

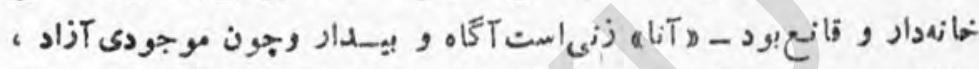

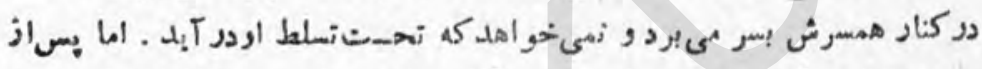

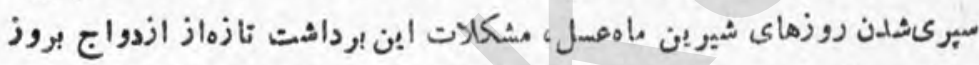

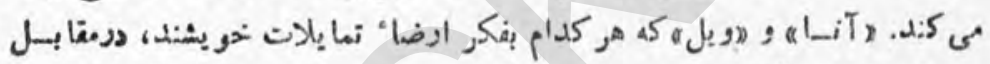

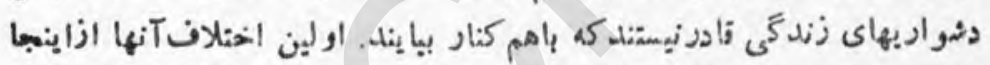

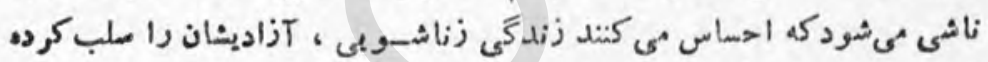

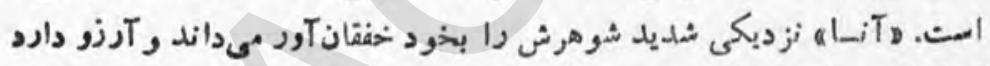

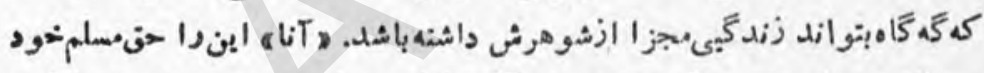

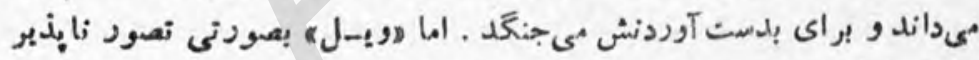

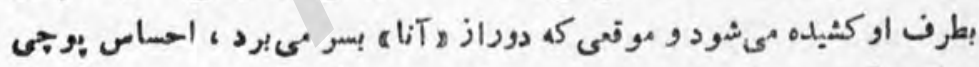

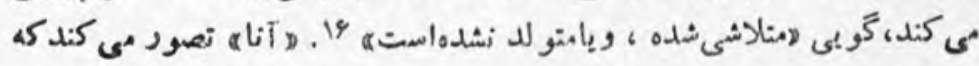

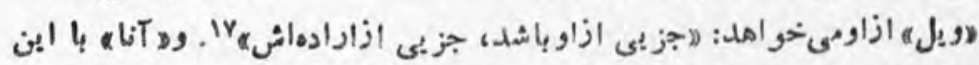

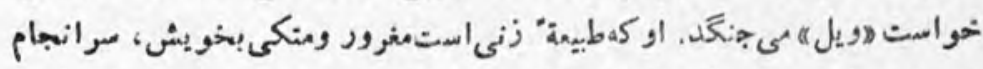

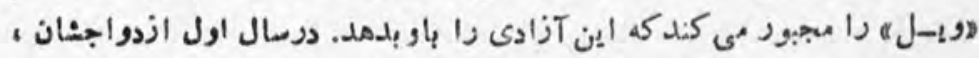

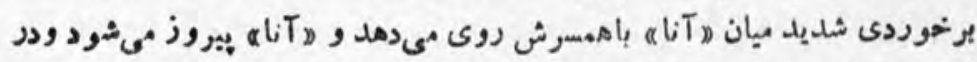

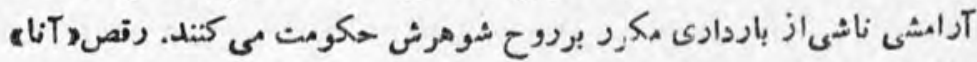

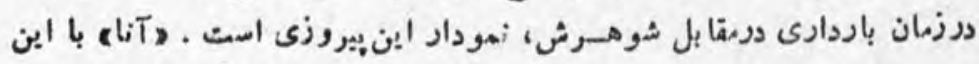

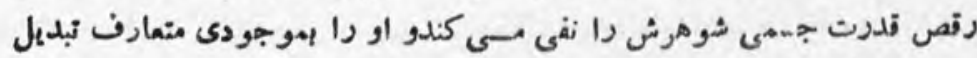

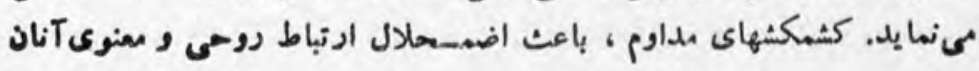


ryq

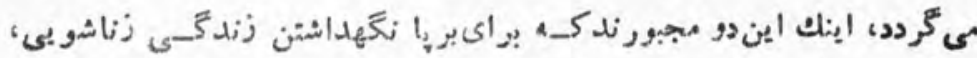

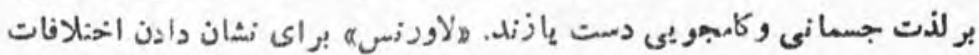

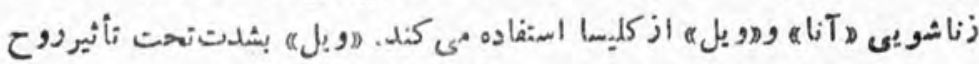

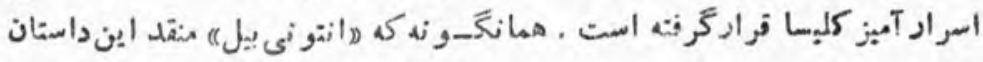

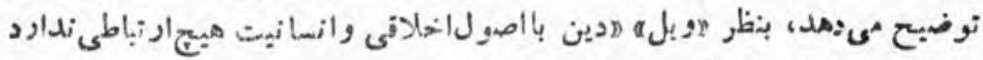

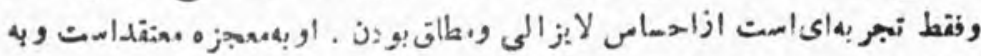

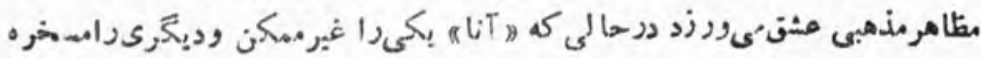

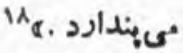

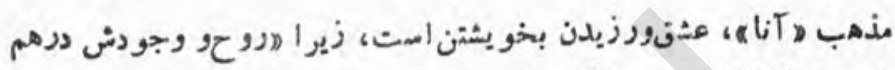

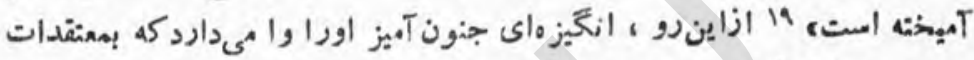

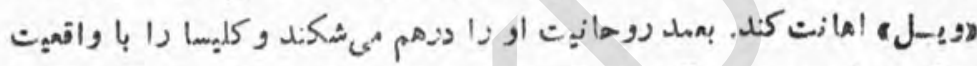

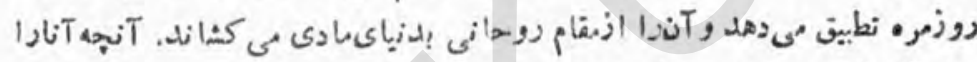

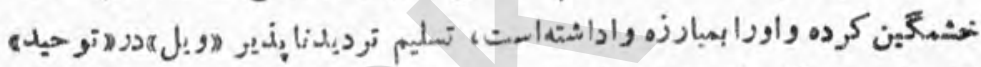

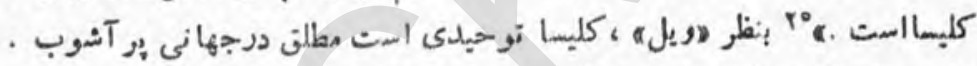

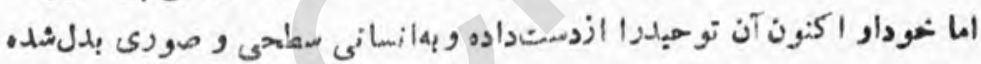

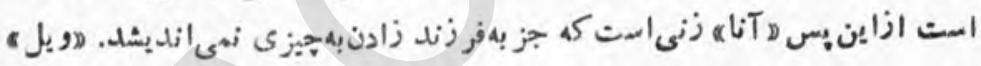

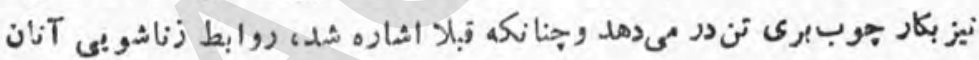

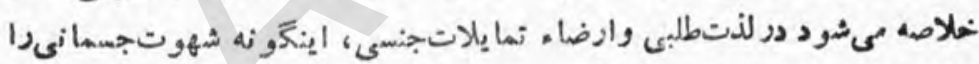

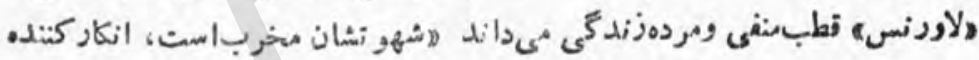

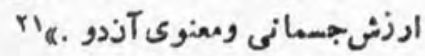

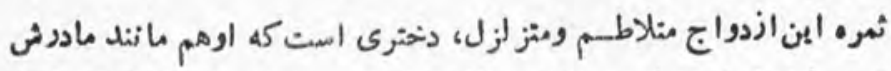

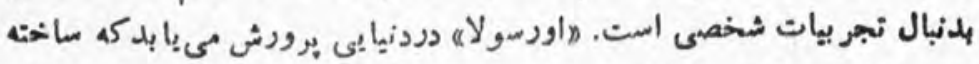
دست زسل جديد وجهوان است. باين تر تيب .شكالات انطباففرد باجاهيه براى

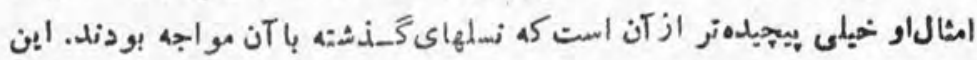

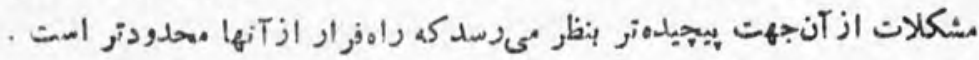

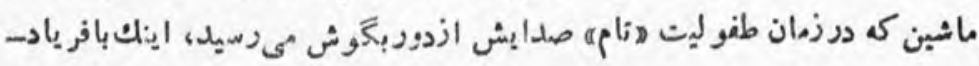

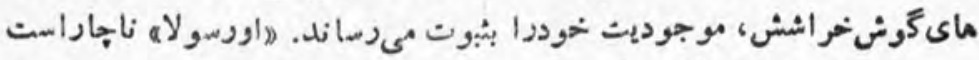

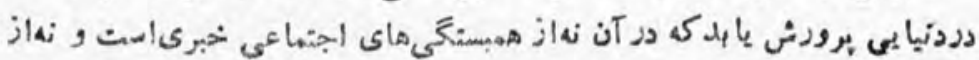


rpsos ro.

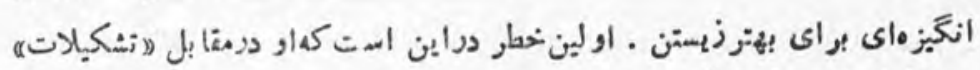

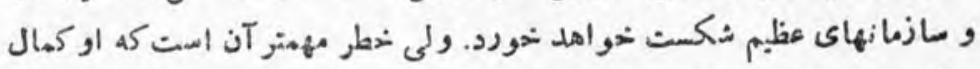

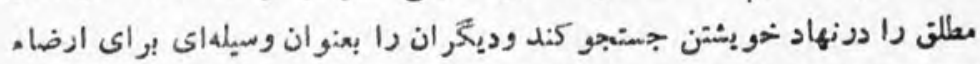

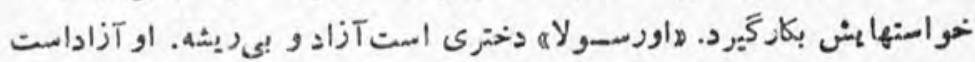

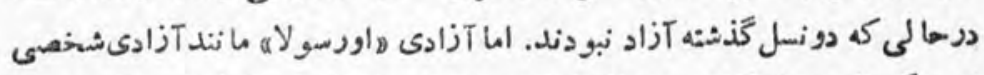

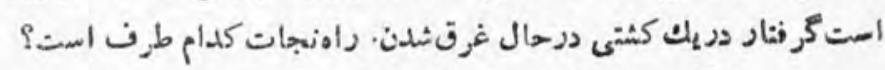

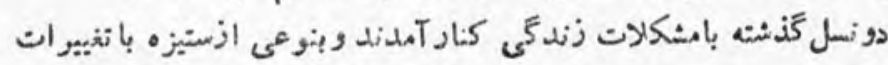

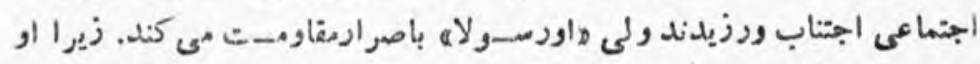

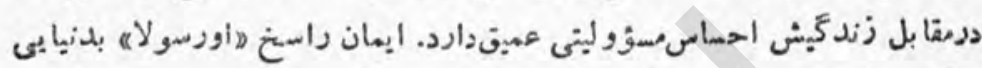

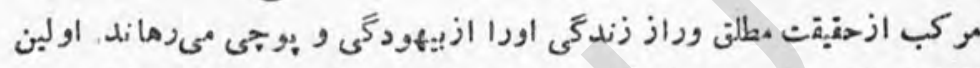

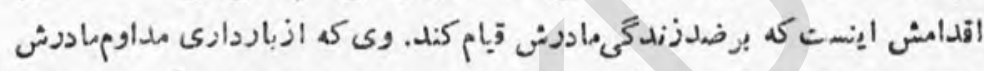

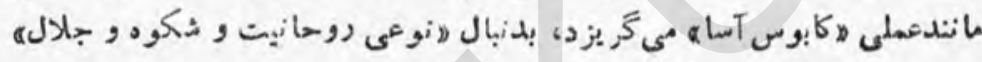

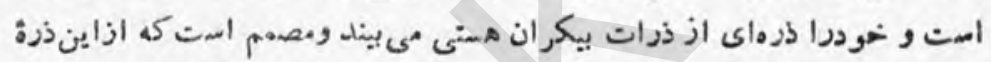

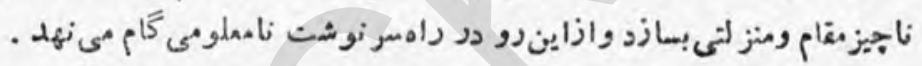

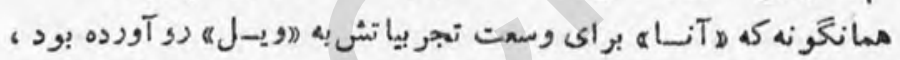

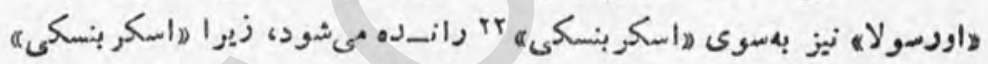

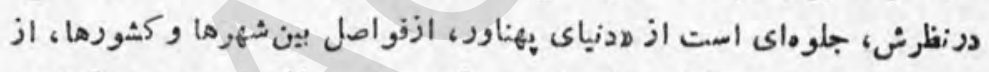

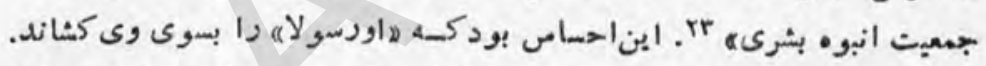

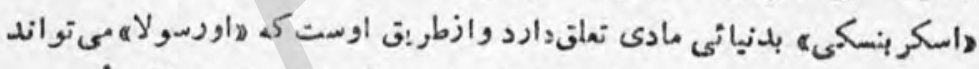

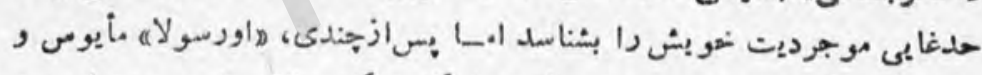

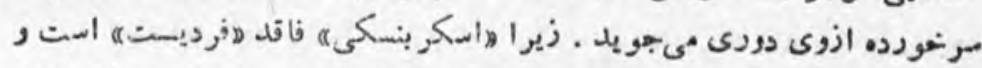

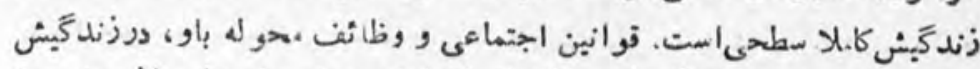

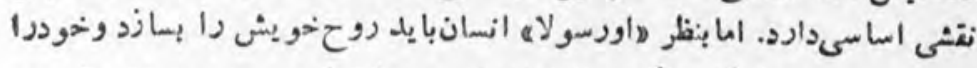

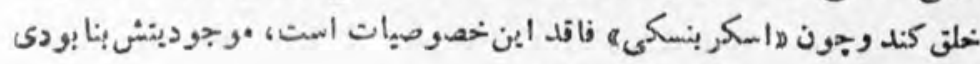

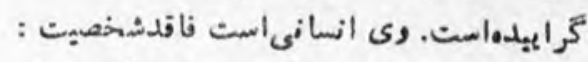

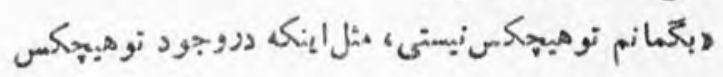

$$
\text { اصلابكر, تو كهمسنى ؟ بنظارم توهيج نيستى" }
$$


rol

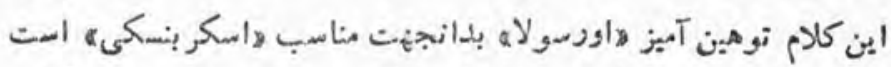

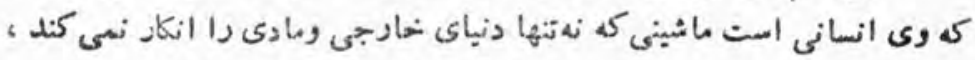

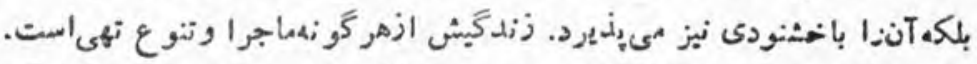

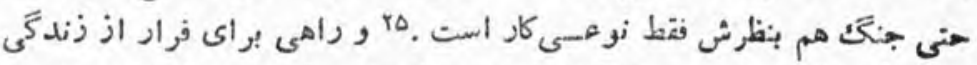

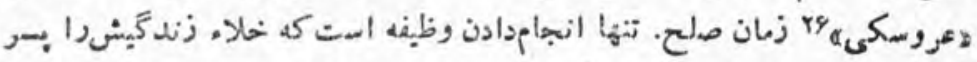

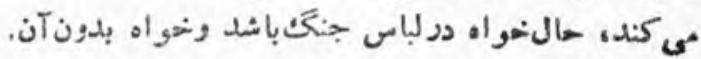

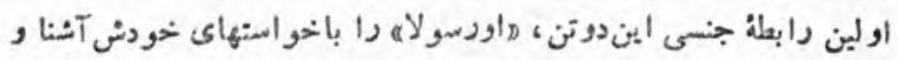

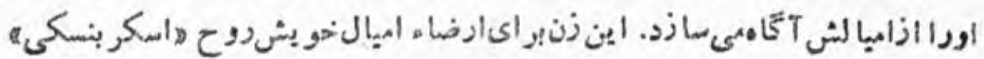

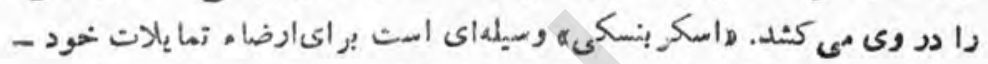

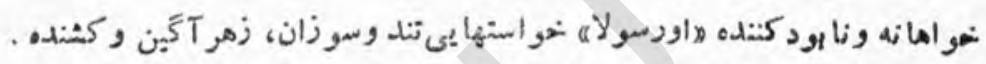

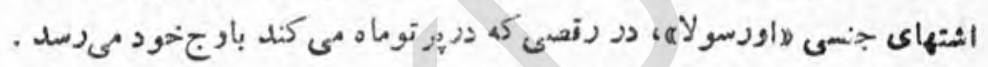

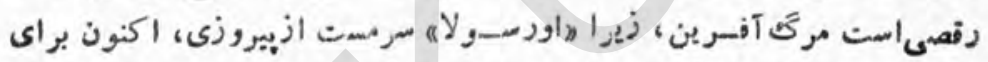

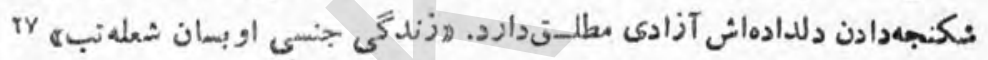

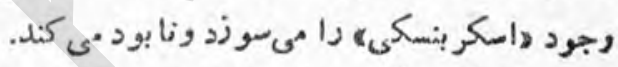

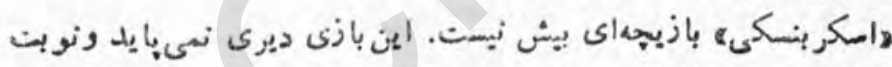

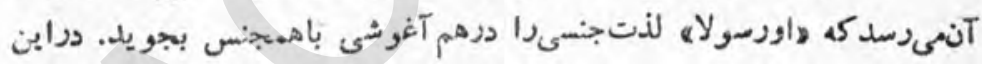

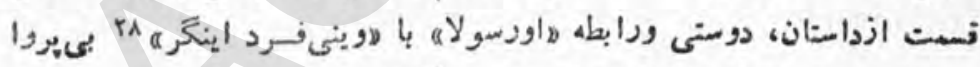

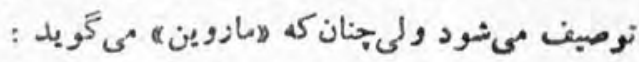

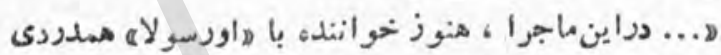

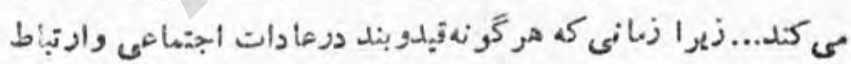

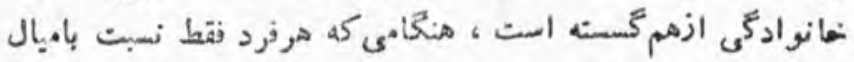

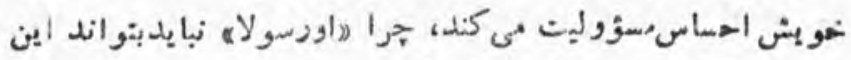

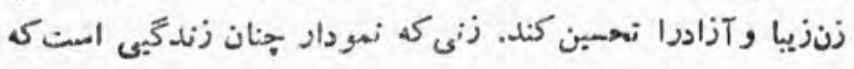

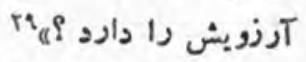

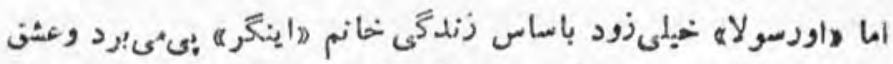

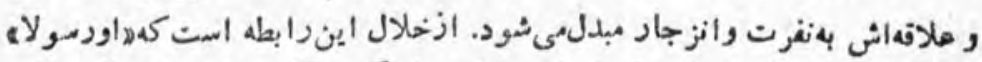

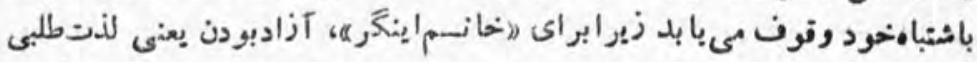

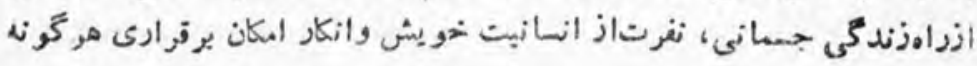




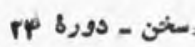

ارتباط روحى بالباء بشر. ايندريانتى است كه هاورسولاه) دربازديدث ازمدلن

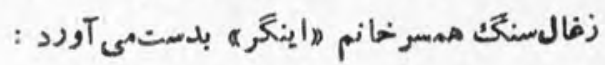

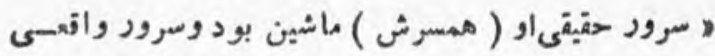

هوينىفرده نيز ماشين بود. (اوينى فرده نيز، تجريد ناخحا الص وحريكات

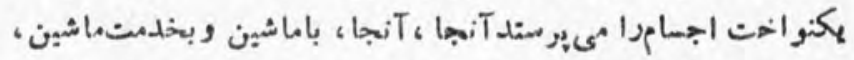

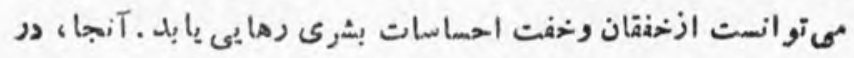

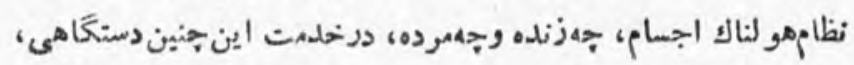
ارضاء ^ى ثد، هم آهنگ

$$
\text { roه }
$$

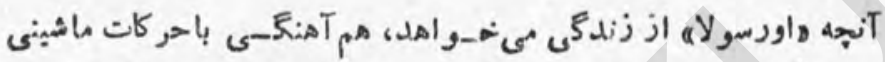

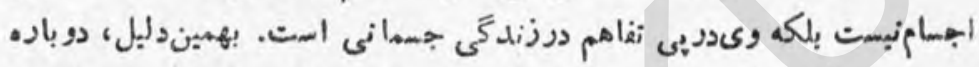

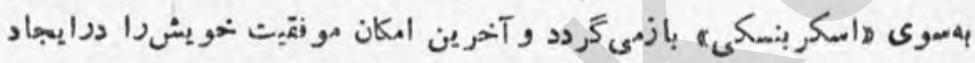

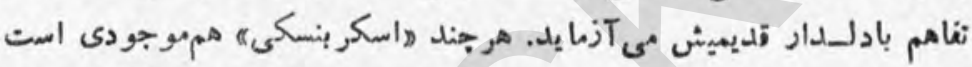

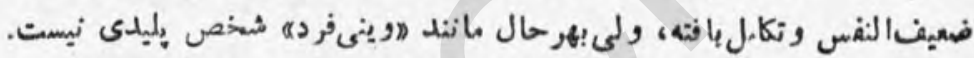

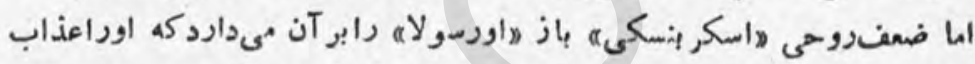

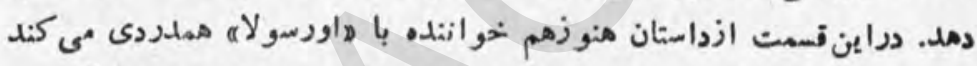

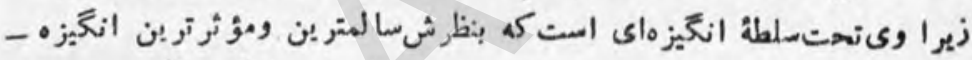

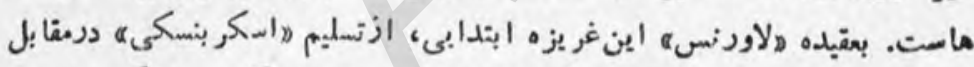

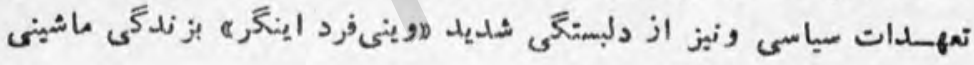
اساسى تراست.

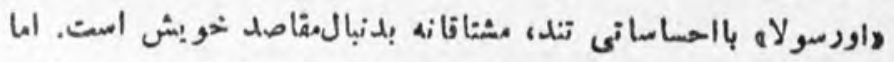

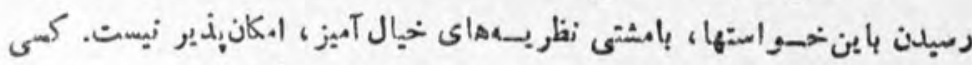

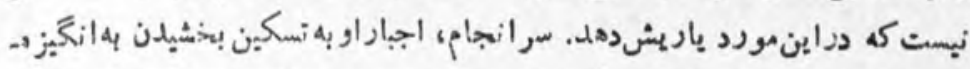

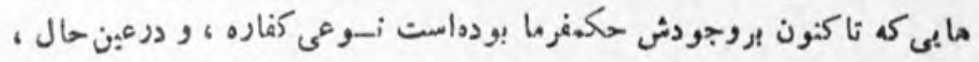

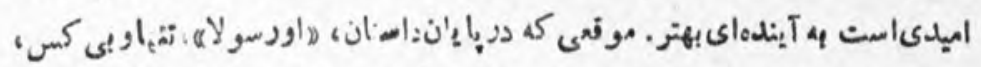

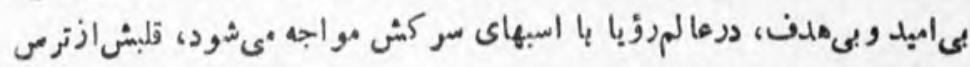

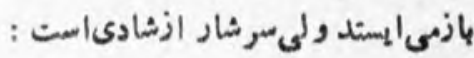




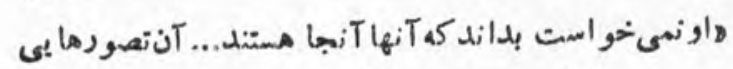

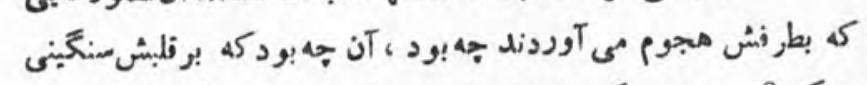

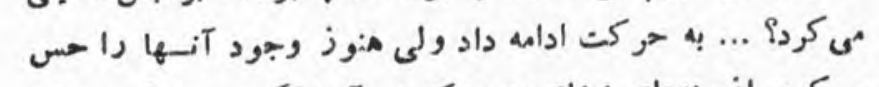

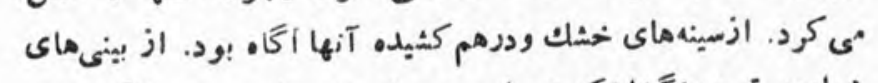

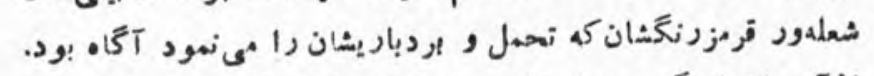

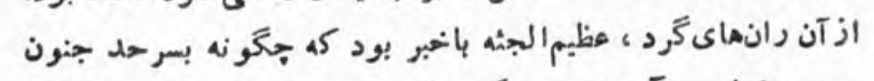

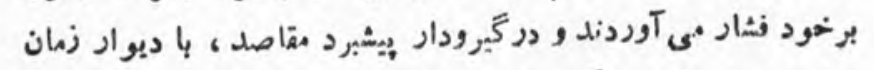

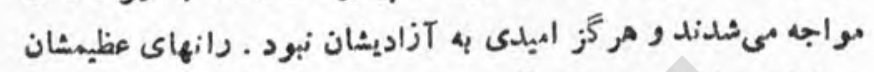

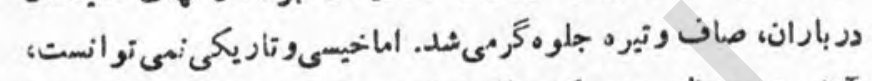

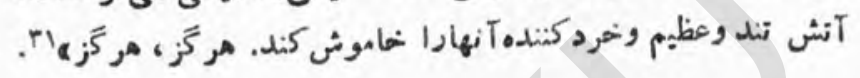

درطول داستان هارنغين كمانه ، اسب نمودار فدرت جنسى مرد است .

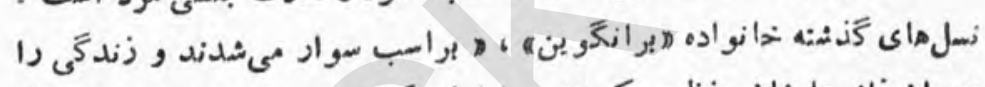

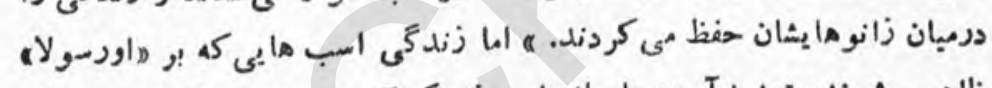

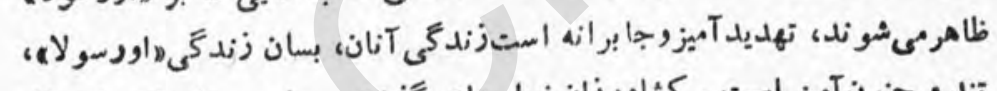

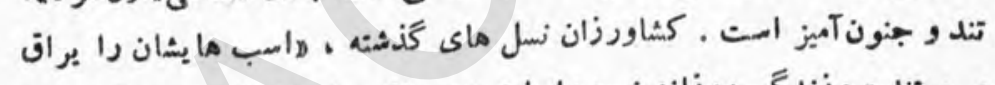

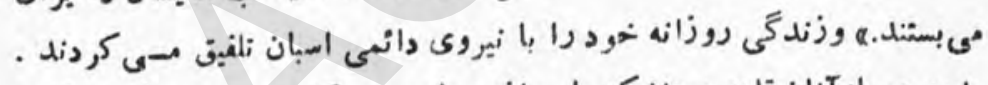

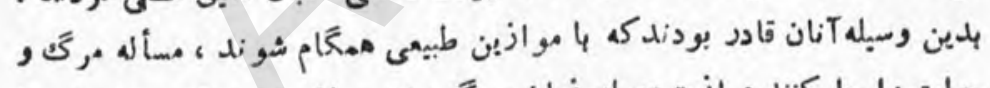

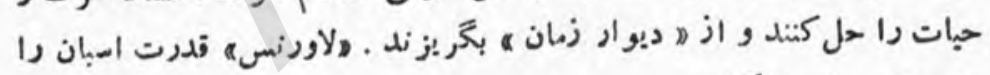

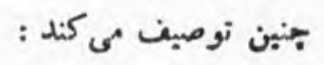

עدر Tان دوردست، در تاريكى روحمان اسب سمهابش دا

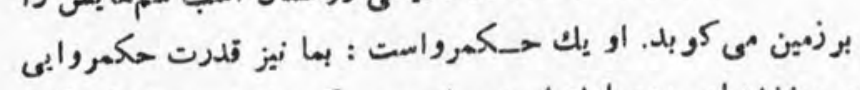

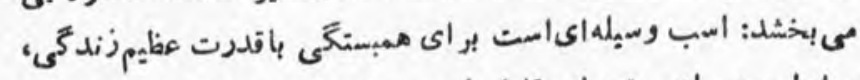

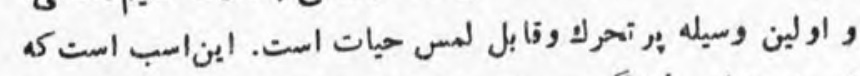

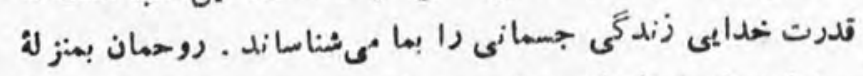

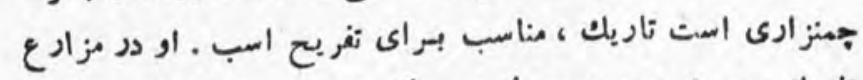

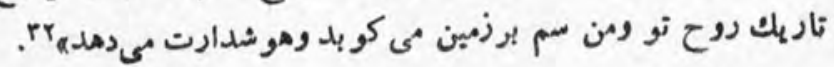




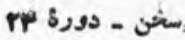

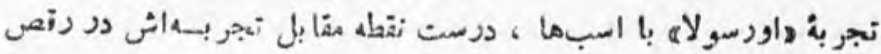

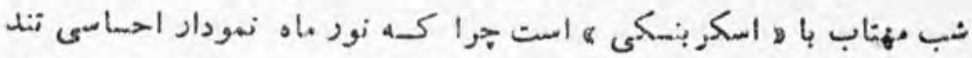

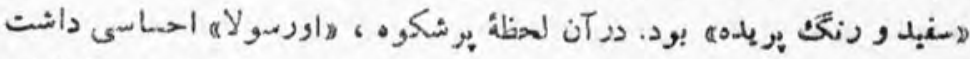

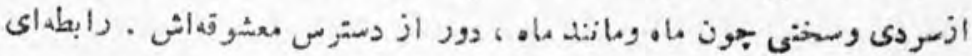

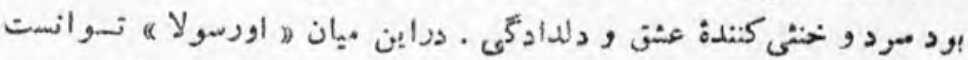

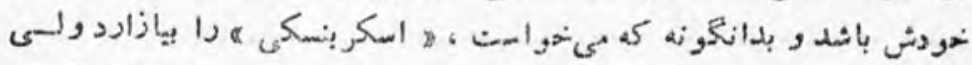

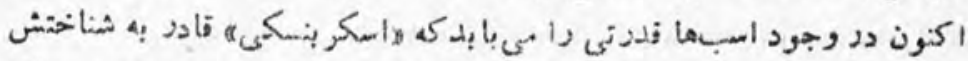

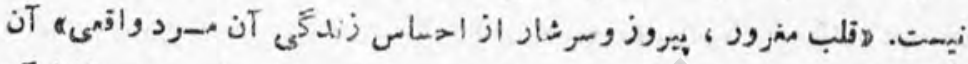

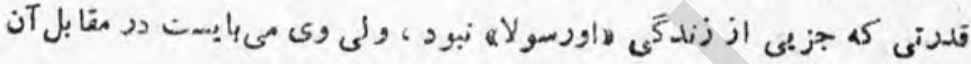

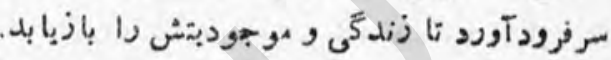

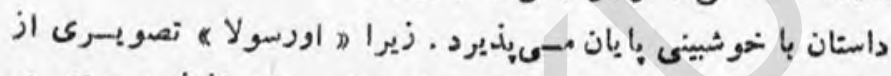

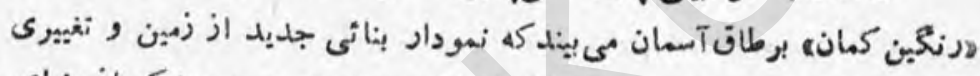

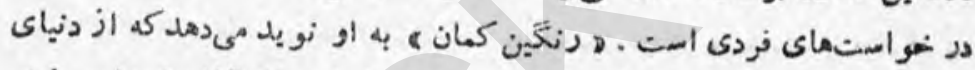

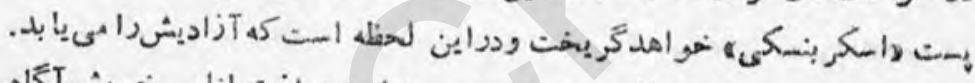

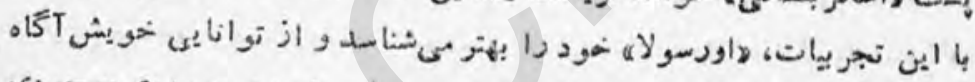

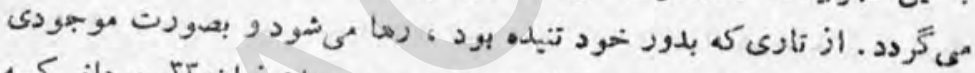

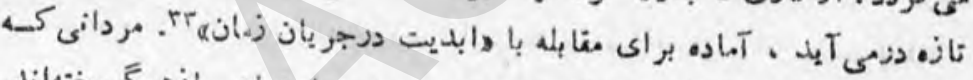

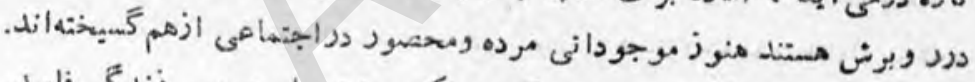

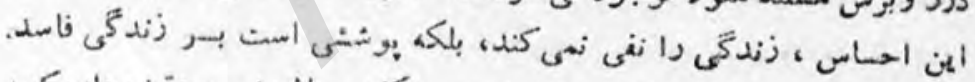

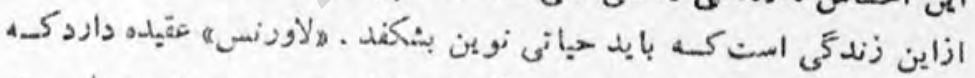

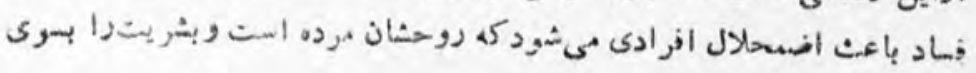

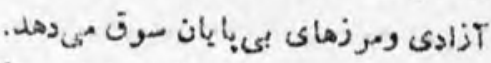

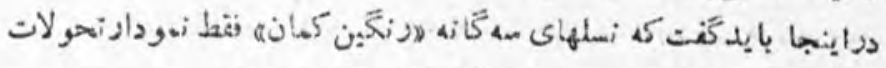

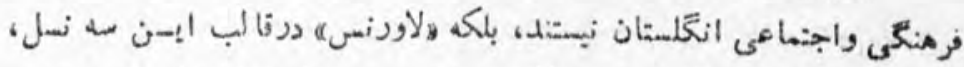

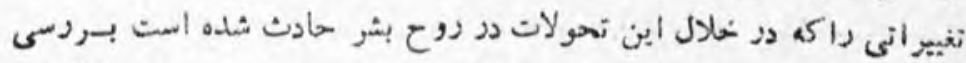

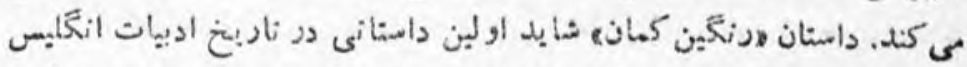

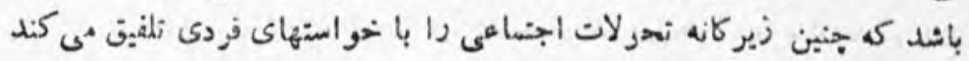

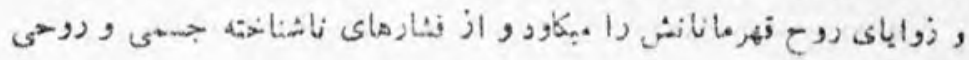


$r \Delta \Delta$

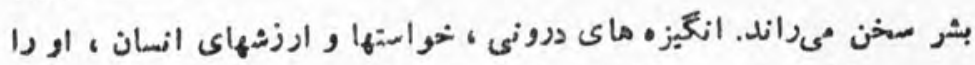

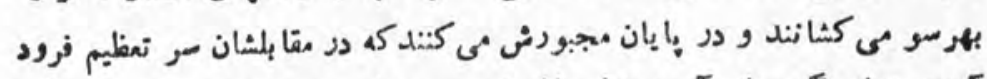

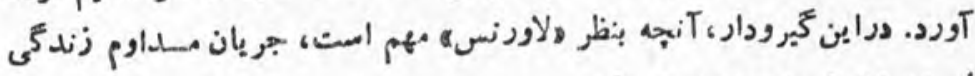
است، وهنتى وبوجوديت بشر.

تهفيق از: موضيه سميعى

Bibliography

1. Lawrence, D.H.: The Rainbow, New York, 1943.

2. Mudrick, Marvin: «The Originality of the Rainbow», Twentieth Century Interpretations of The Rainbow, edited by Mark Kinkead-Weekes. Printice Hall, Inc. 1971, p. 22.

3. Brangwen 4. Tom 5. Anna 6. Will 7. Ursula

8. Goldberg, S.D.: «Fiddle-Bow \& Sand». D. $H$ Lawrence, $\mathrm{T}$ he Rainbow and Women In Love. Ed. by Colin Clark, Case Book Series, 1969, p. 119.

9. Lydia

10. The Rainbow. p. 7.

11. Karl, Frederick R. \& Magalaner, Marvin: A Reader's Guide To Great 20 th Century English Novels, London, 1973, p. 176.

12. Daleski, H. M.: The Forked Flame, A study of D. H. Lawrence, London, MCMLXVIII, p. 85.

13. Spilka, Mark: The Love Ethic of D.H. Lawrence, Indiana Univ. Press., 1971, p. 98.

14. The Rainbow, p. 104.

15. Ibid, p. $141 . \quad$ 16. Ibid, p. $158 . \quad$ 17. Ibid, p. 191.

18. Beal, Anthony: D. H. Lawrence, London, 1964, p. 32.

19. Forked Flame, p. 103.

20. Pritchard, R.E.: D.H. Lawrence: Body of Darkness, London, 1971 , p. 73. 
سخن- دورל Pp ró

21. The Rainbow, p. 266.

22. Skrebensky.

23. The Rainbow, p. 275-76.

24. Ibid, p. 293.

25. Ibid, p. 291.

26. Ibid, p. 291.

27. Ibid, p. 291.

28. Winifred Inger

29. Originality of the Rainbow, p. 29.

30. The Rainbow, p. 330.

31. Ibid, p. 459-60.

32. Lawrence, D.H.: «Apocalypse», ch 10, from 20 th Cent. Interpretations of the Rainbow ed. Mark Kinkead_WWeks, p. 67.

33. The Rainbow, p. 464. 


\section{اسكندرناهه \\ ALEXANDII A \\ در زبان روماني}

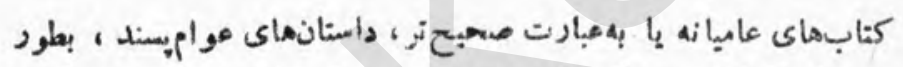

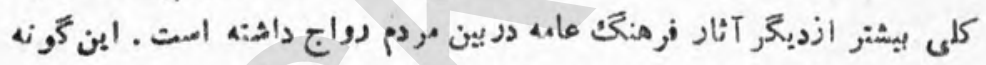

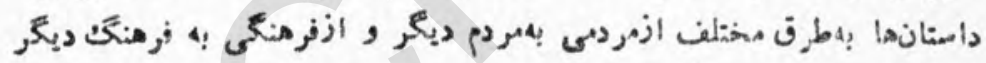

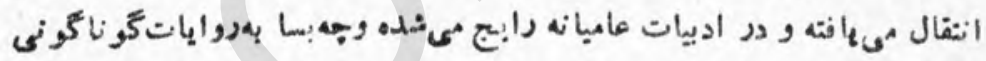

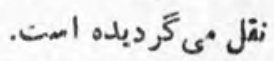

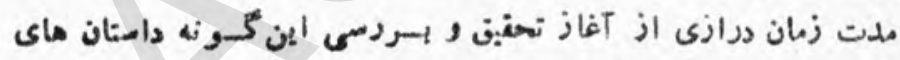

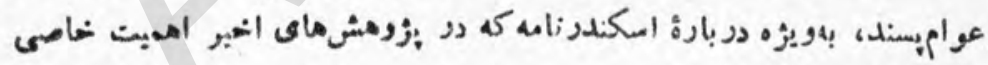

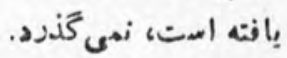

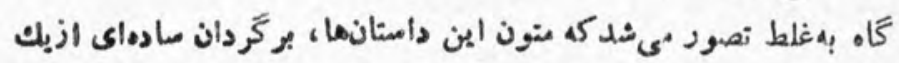

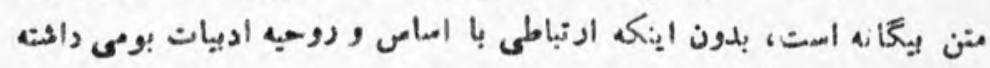

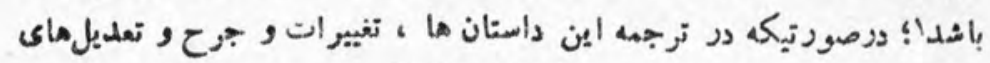

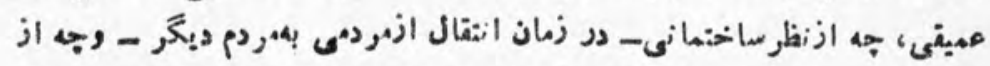

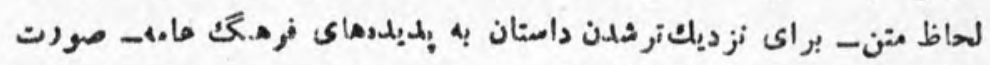

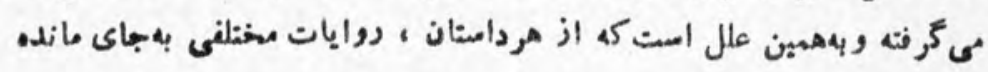

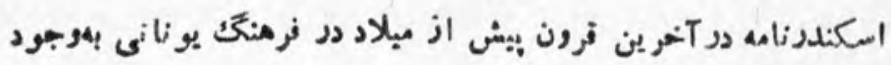

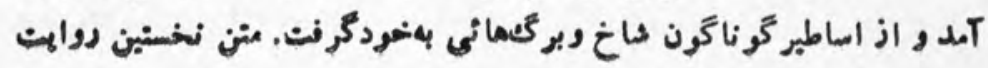


سخن - دورة

اسكندر ناهــه را به مورخ كاليستنس Callisthenes كه در لش كر كشىهاى

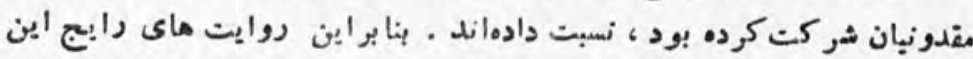

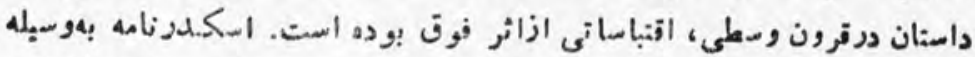

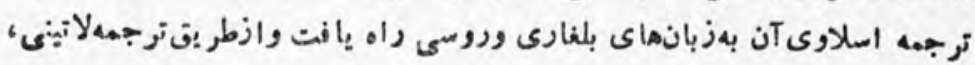

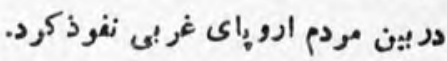

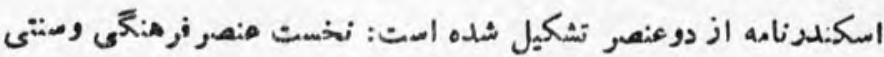

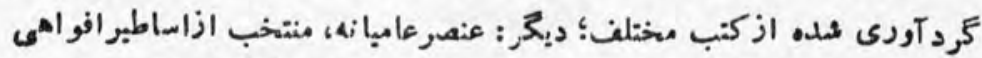

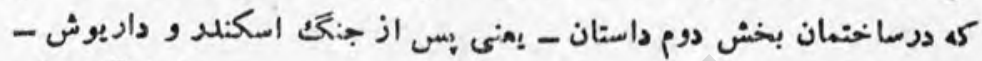

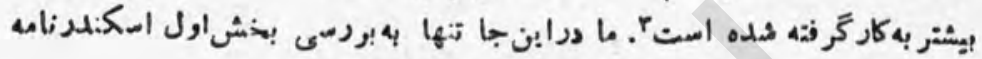

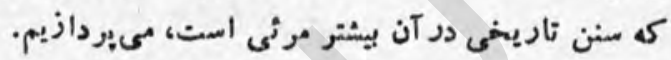

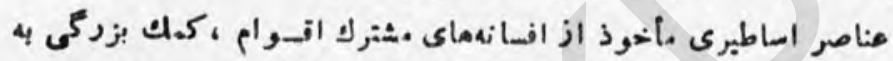

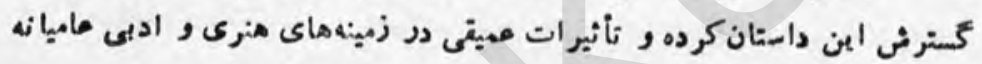

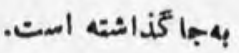

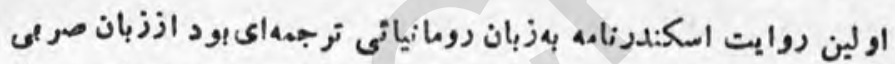

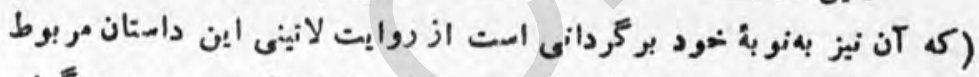

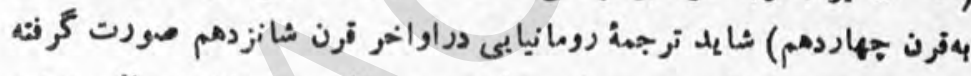

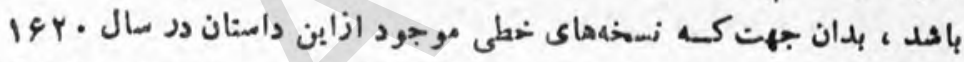

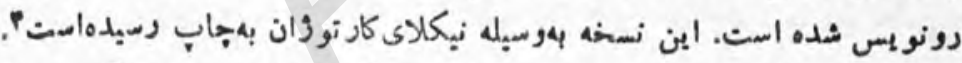

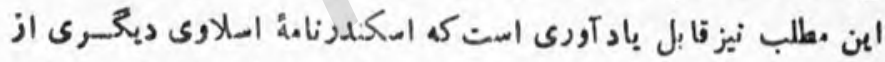

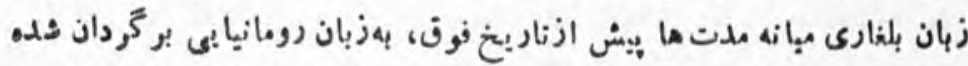

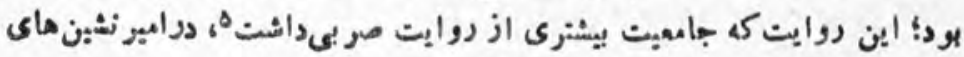

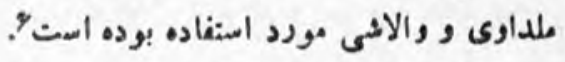

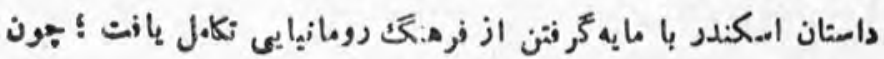

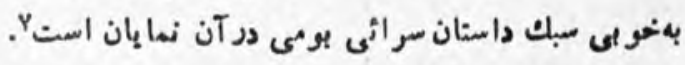

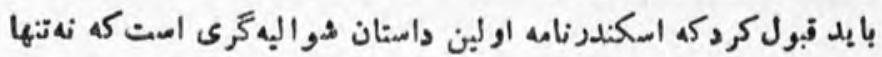

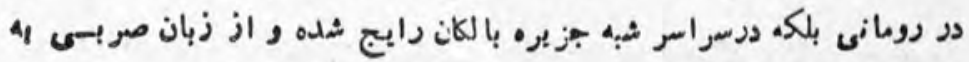
دوسى تدميم راه با فنه است. 
ros

امكندرزامه

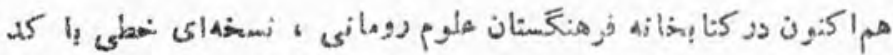

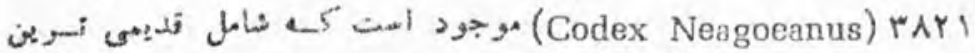

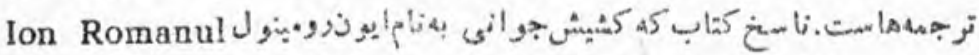

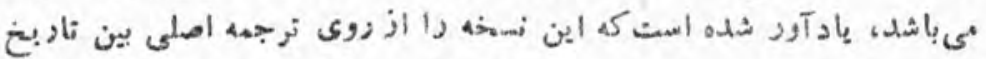

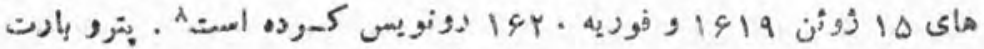

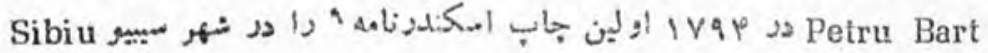
منتشر كرد. - م

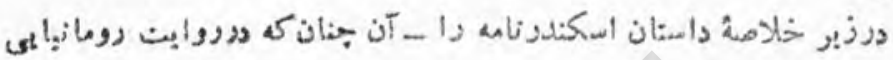

$$
\text { : } 10 \text { مان }
$$

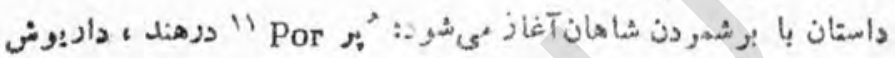

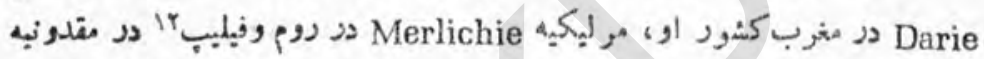

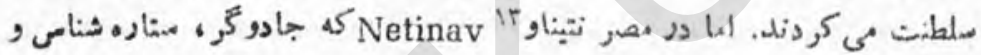

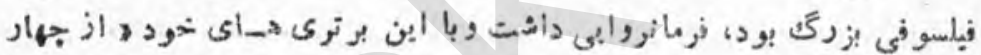

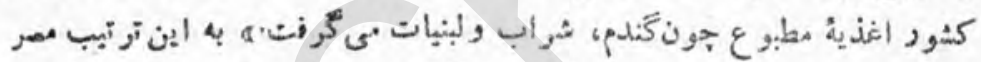

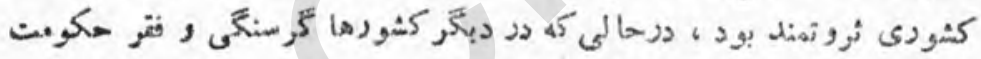

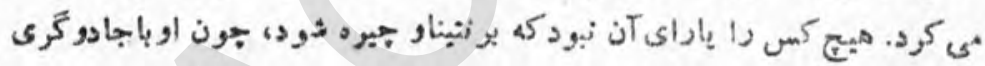

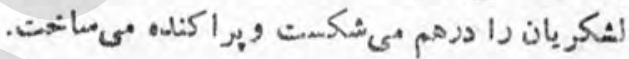

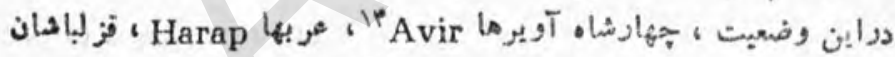
و وجشى Cazilbas

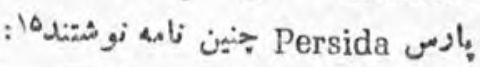

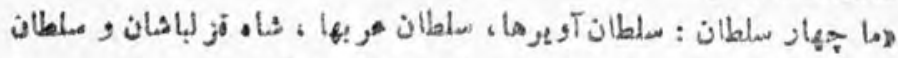

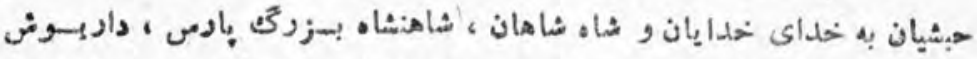

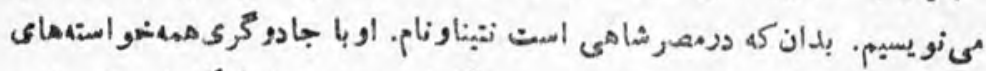

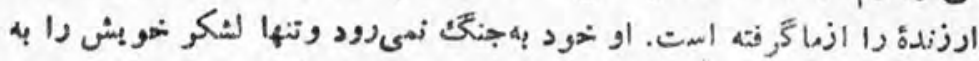

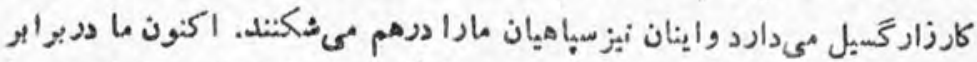

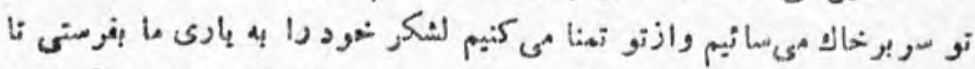

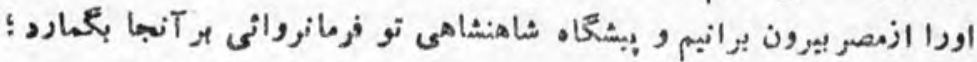

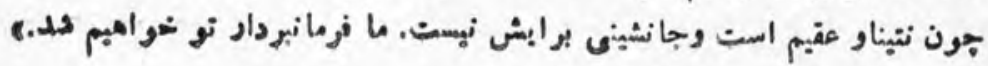


rposo a d on $=$ re.

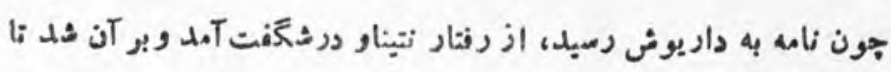

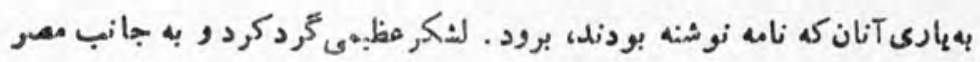

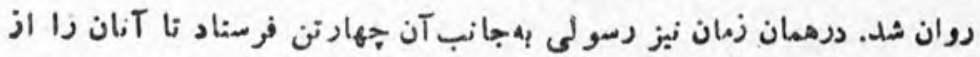

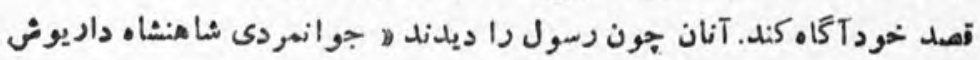
را ستودند ه وروليس Vervelis مصرى جون سمياه دشمن را ديد كه به خطة

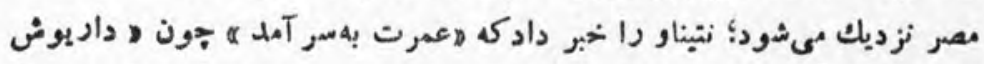

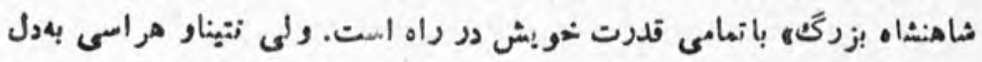

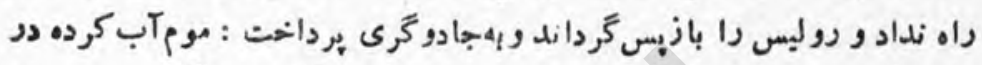

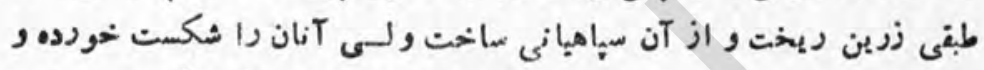

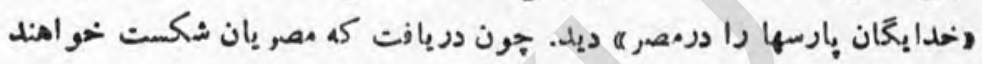

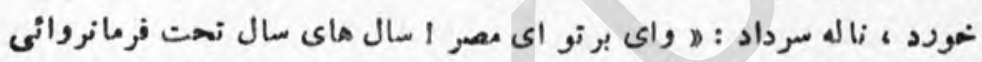

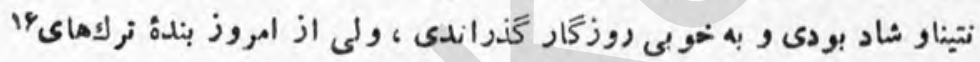

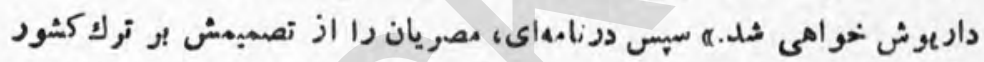

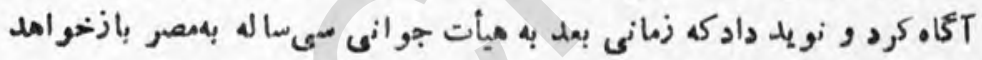

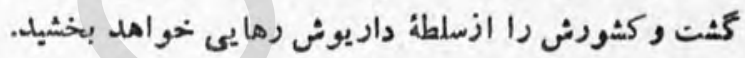

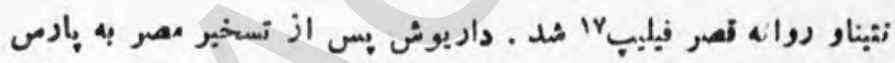

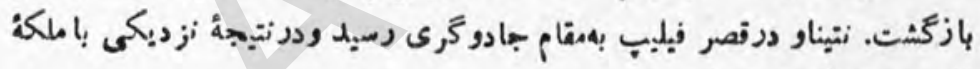
اليهياد، اسكندر منو لد ثمد.

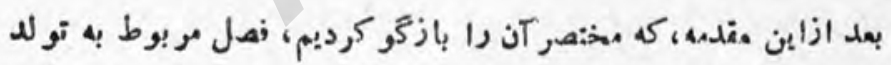

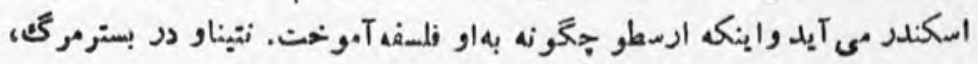

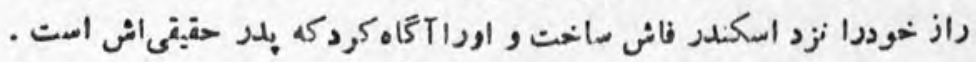

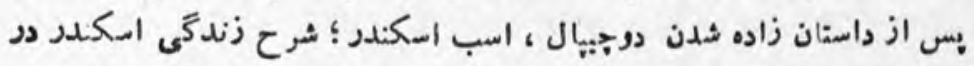

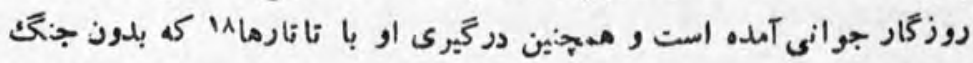

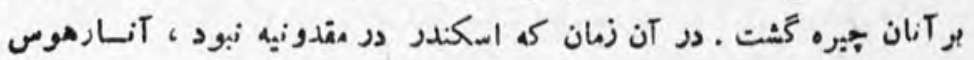
Anarhos بادشاه، بر فيليب بيهار وبير غابه كرد ؛ والى جون اسكندر إه مقدوزيه

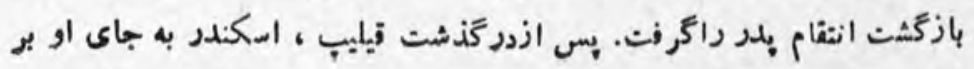




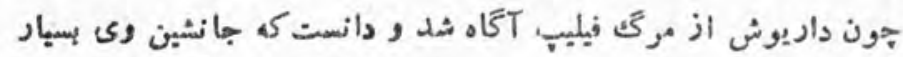

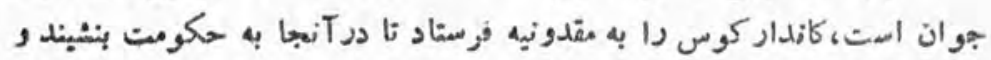

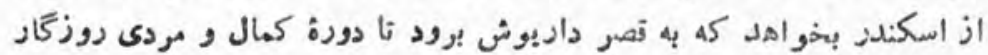

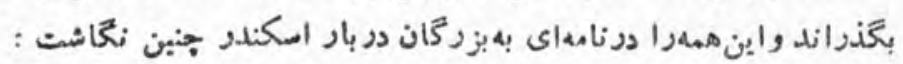

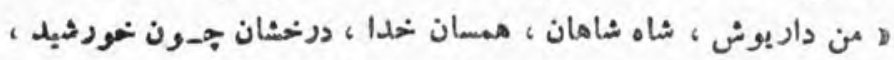

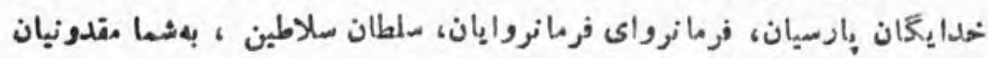

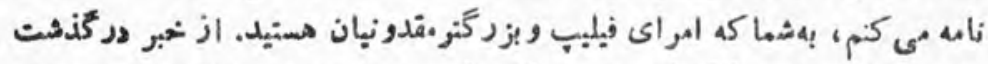

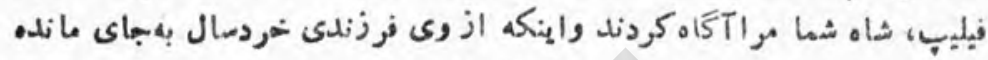

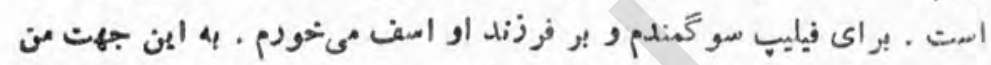

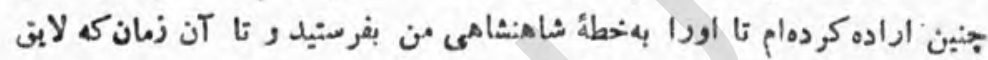

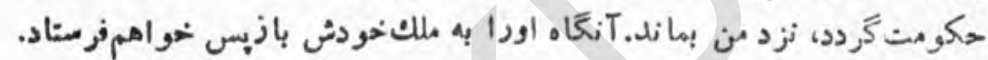

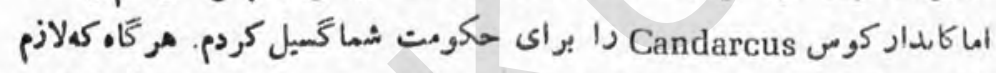

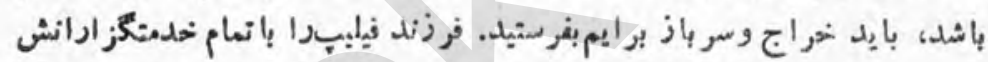

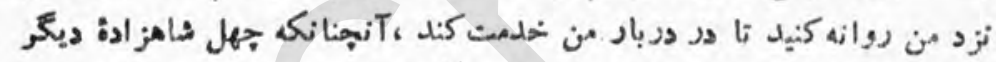

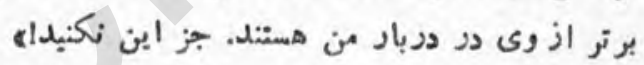

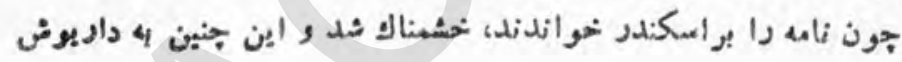

باستخ داد:

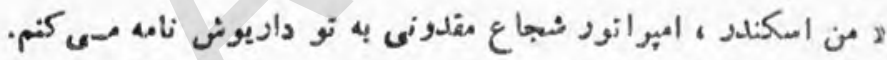

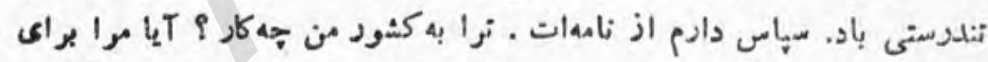

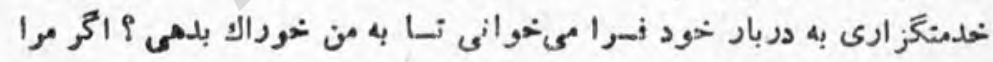

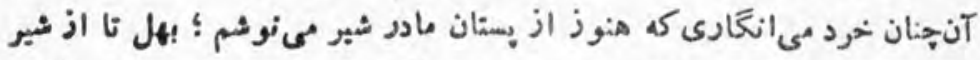

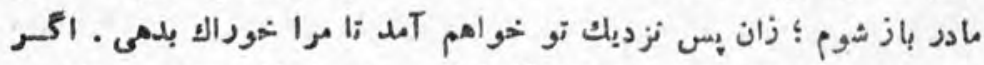

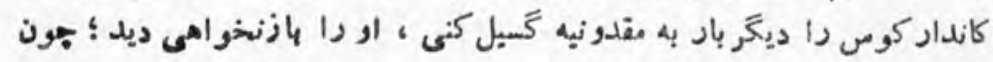

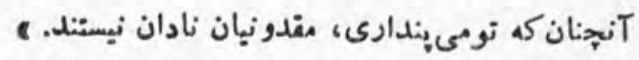

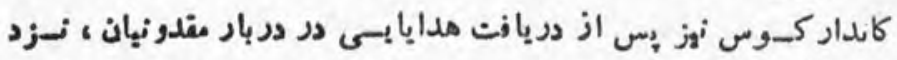

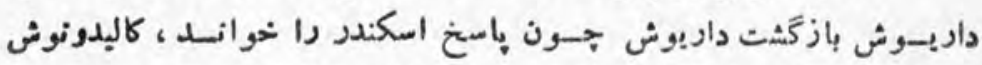
و Calidonus

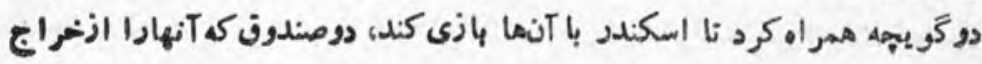


سخن -sورל مب rep

انبا شته كند و دو كيسه مهلو ازخشخاش نا آنهارا بشمارد و از شماره سمربازان

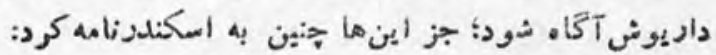

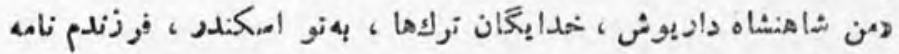

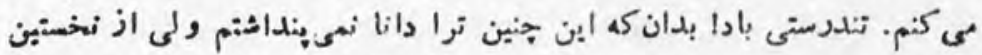

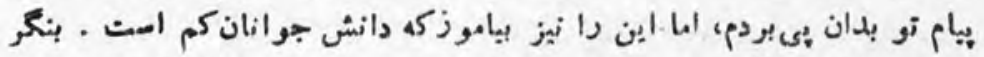

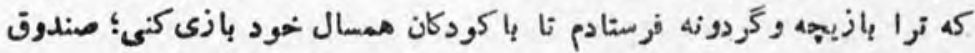

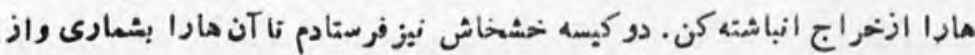

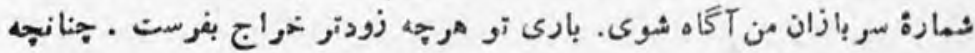

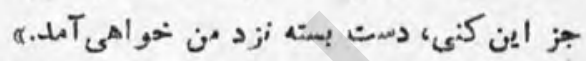

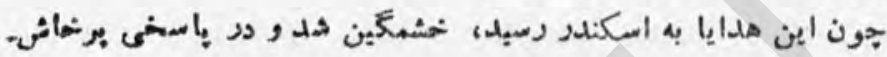

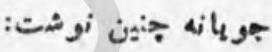

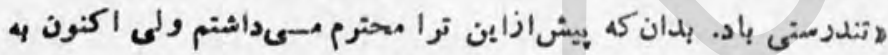

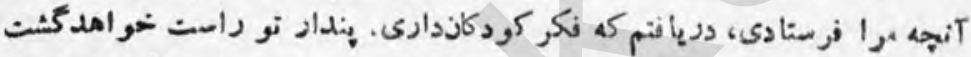

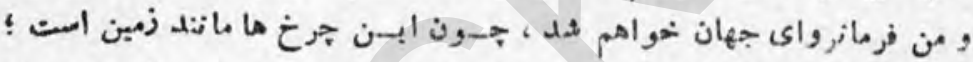

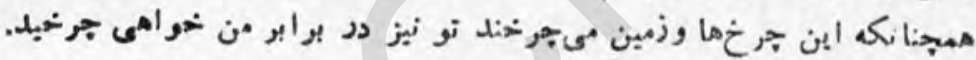

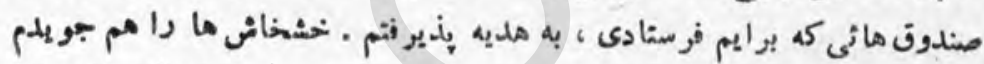

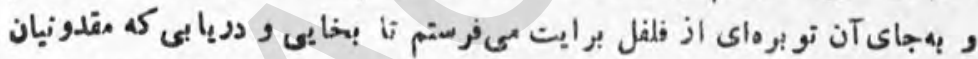

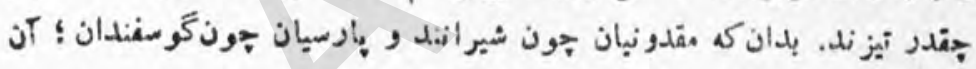

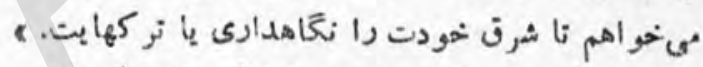

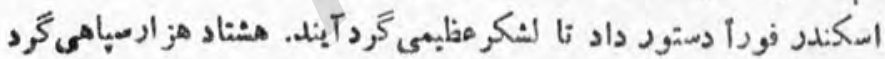

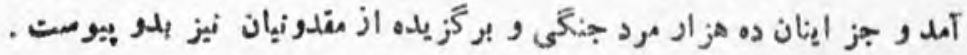

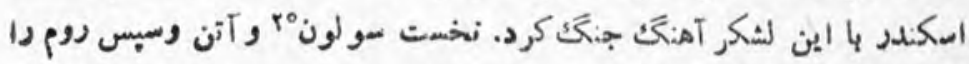

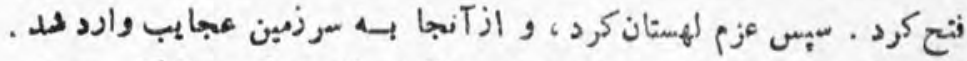

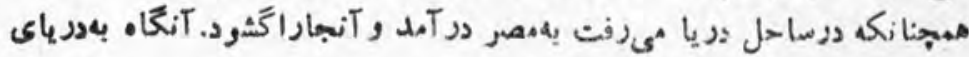

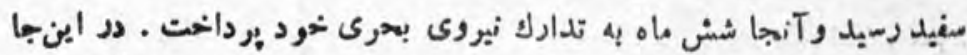

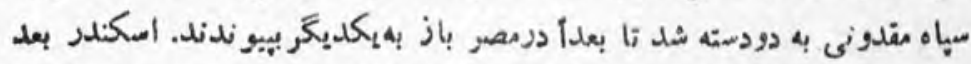

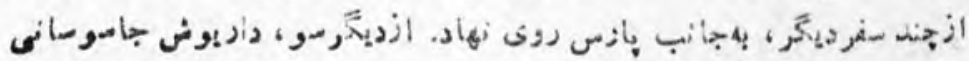

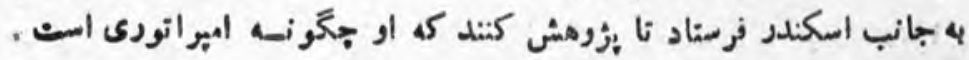




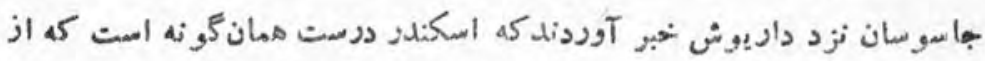
وى توصبيف كردماند: اومردى است عادل، قوى بنجه وأمبر اتود مر أسرجهانه.

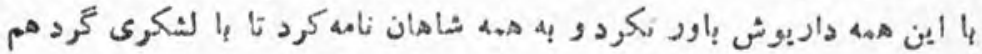

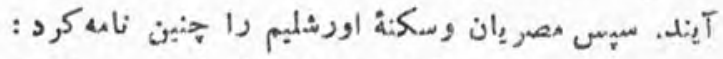

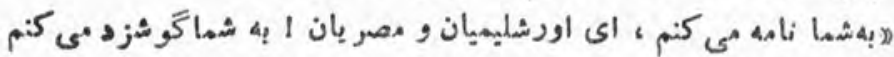

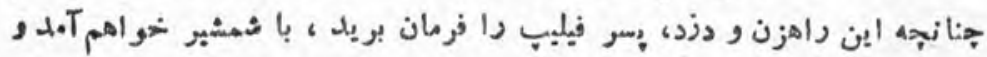

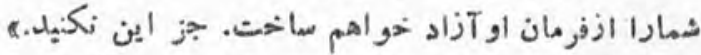

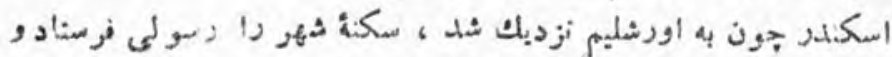

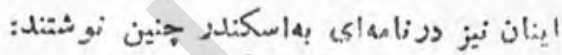

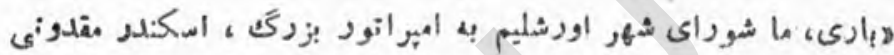

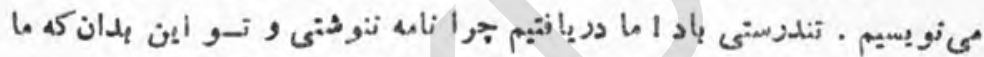

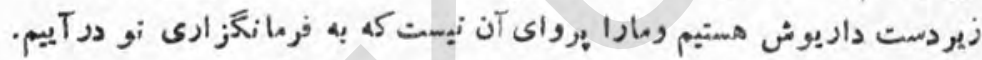

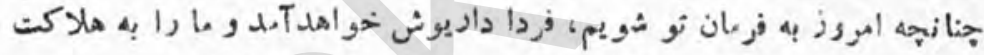

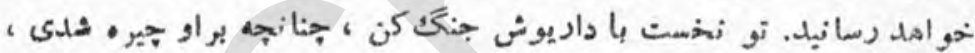

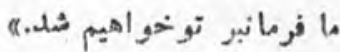

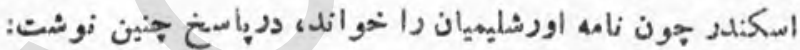

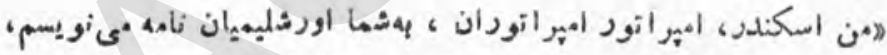

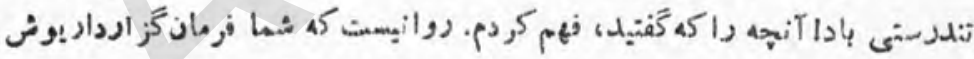

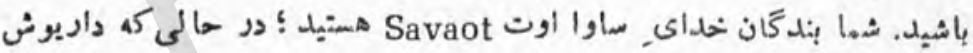

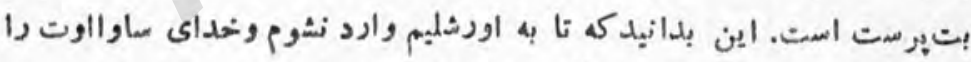

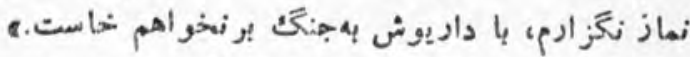

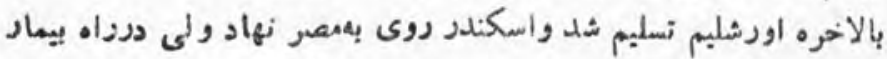

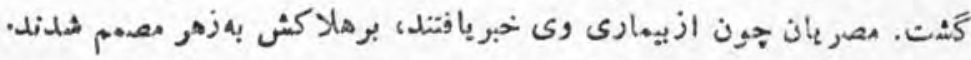

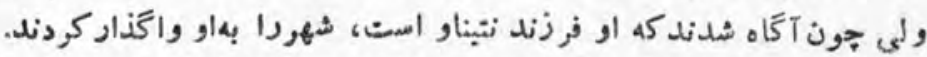

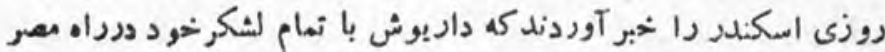

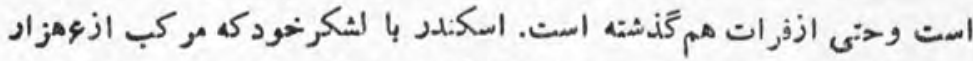

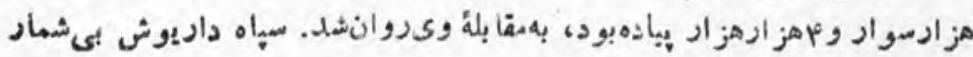

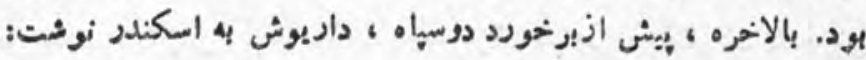




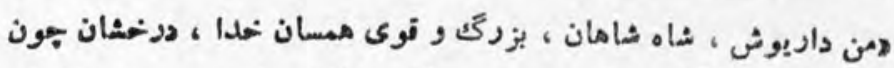

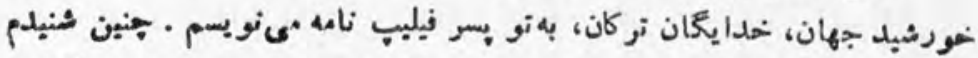

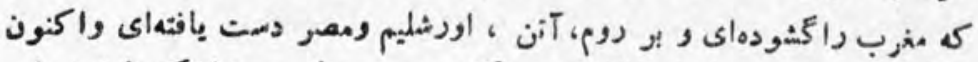

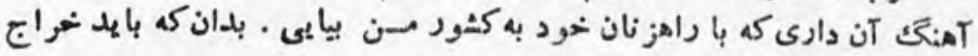

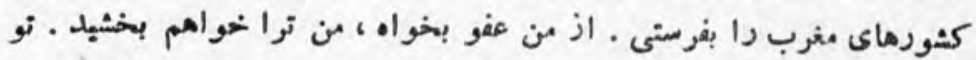

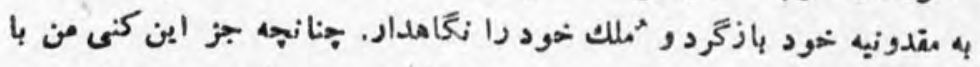

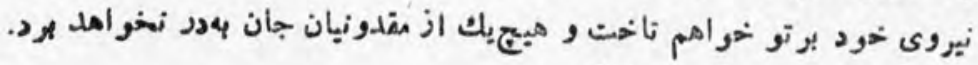

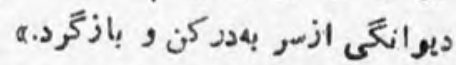

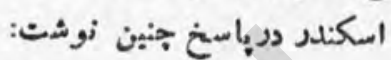

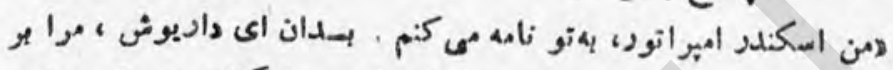

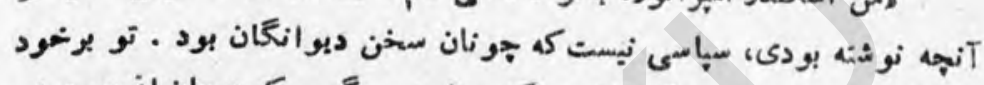

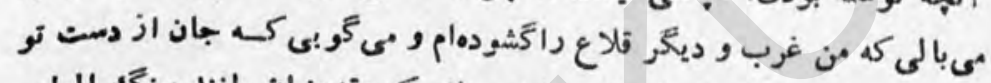

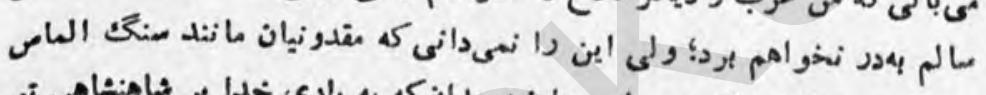

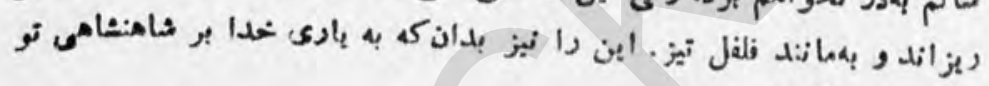

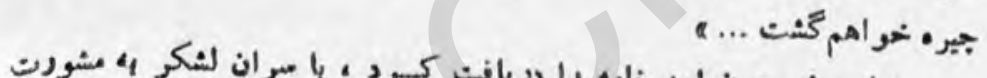

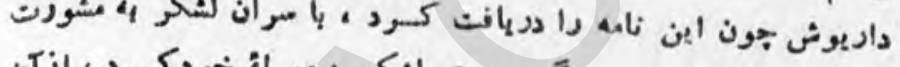

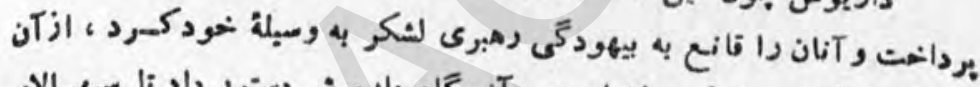

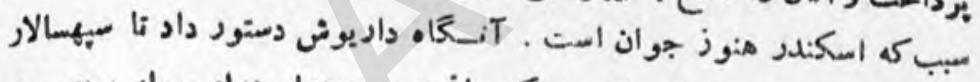

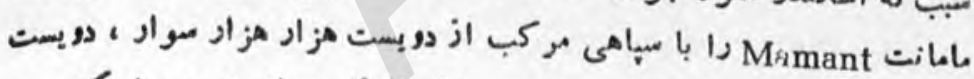

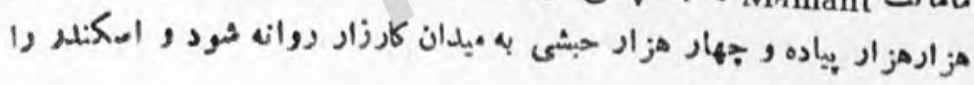
زنده دس:خير كند.

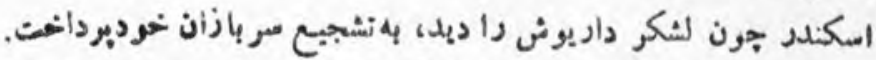

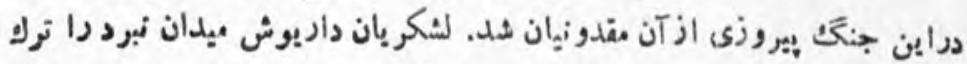

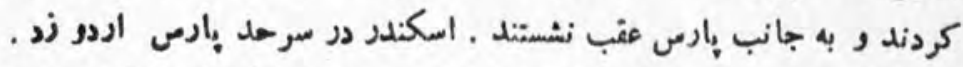

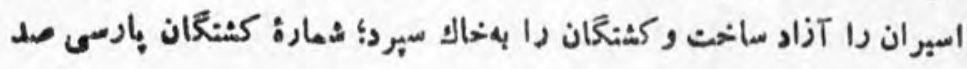

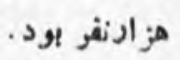

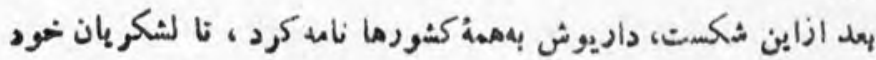

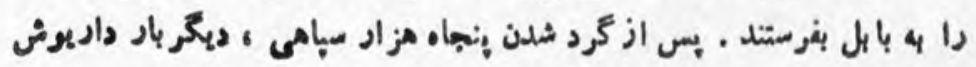




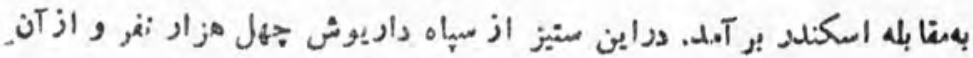

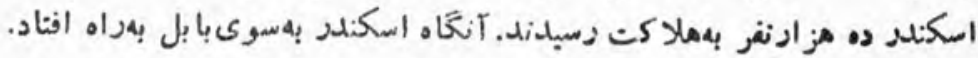

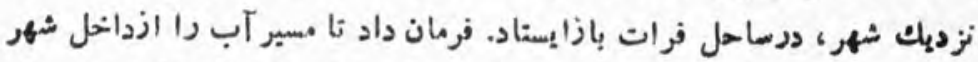

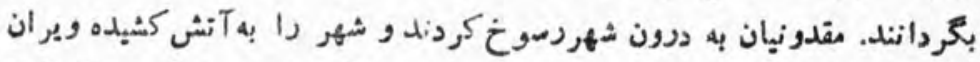

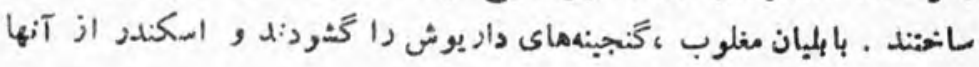

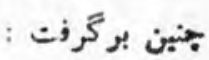

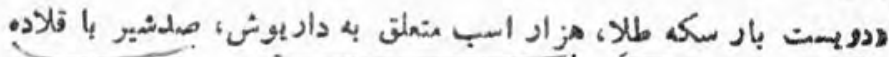

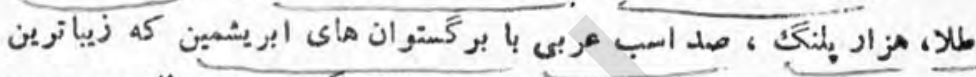

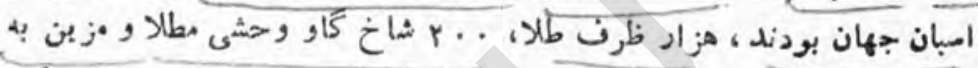

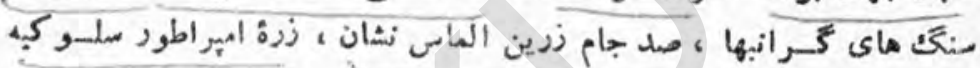

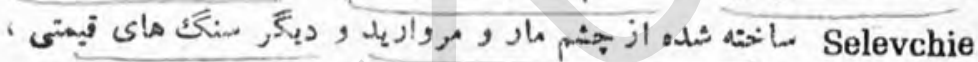

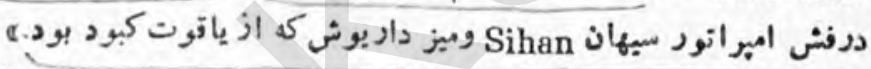

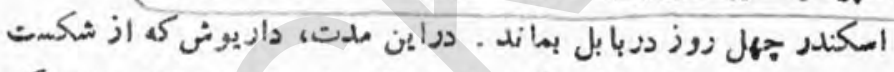

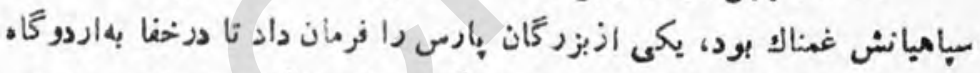

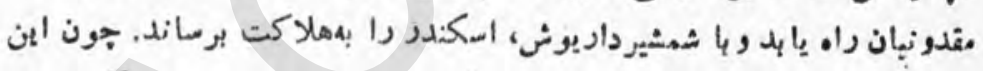

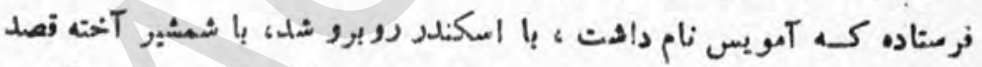

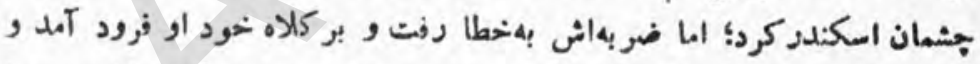

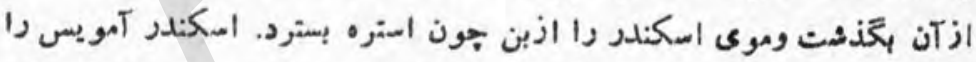

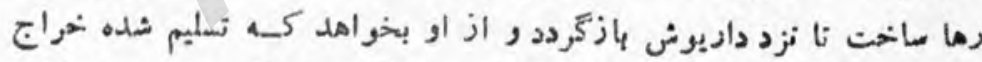

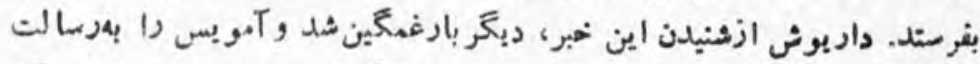

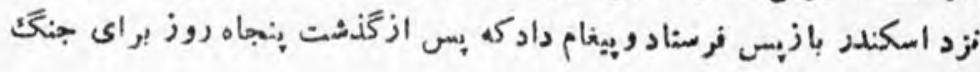
Tماده شود.

إن بار اسكندر خود درهيأت رسولان، بهدربار داريوش دفت. داريوث

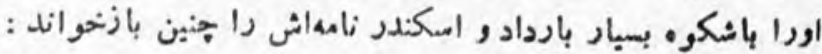

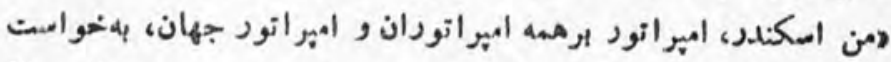

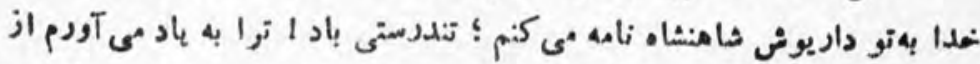

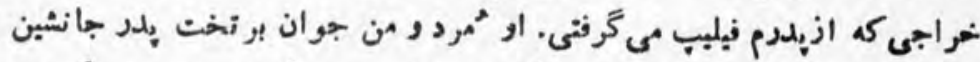

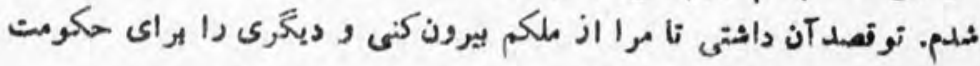




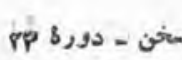

وامبراتورى مندو نبه رخمارى. الما خلداوند آن نخواست كه تو اراده كر دهبودى.

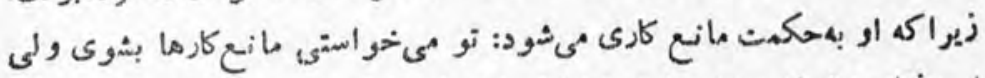

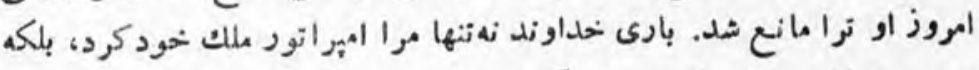

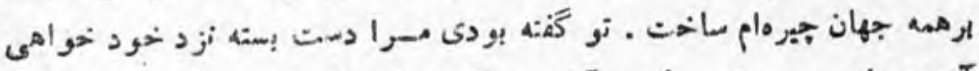

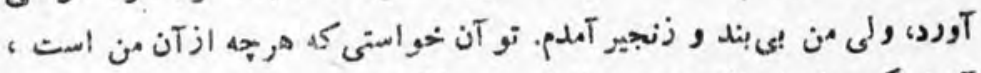

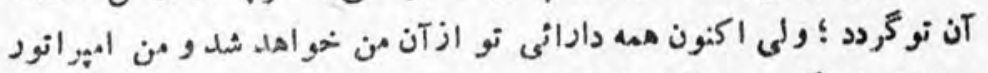

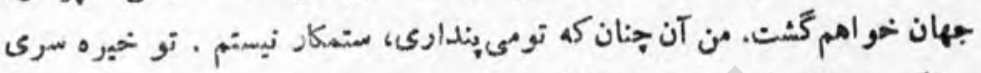

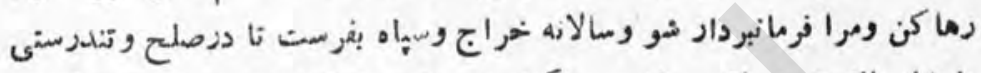

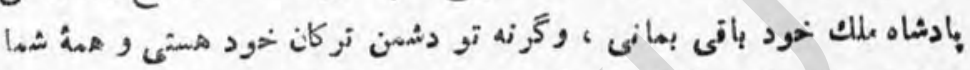

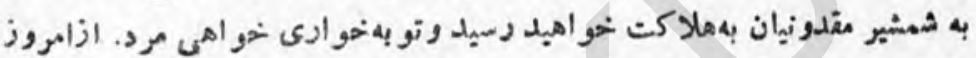

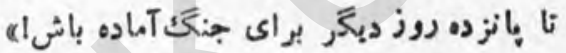

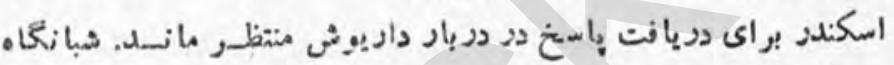

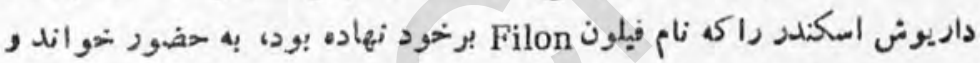

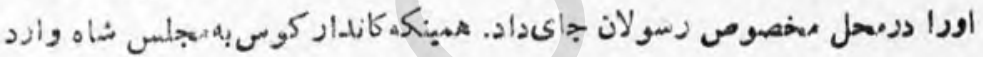

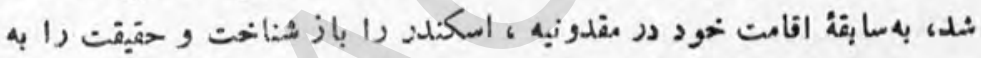

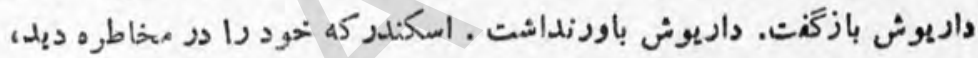

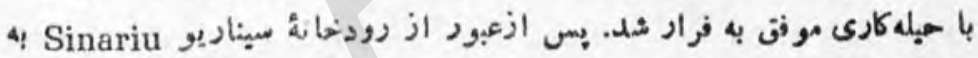

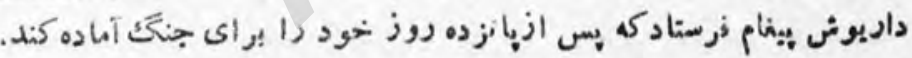

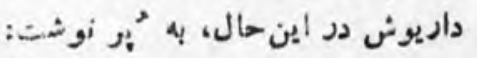

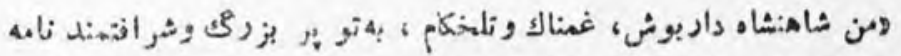

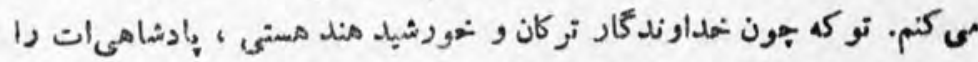

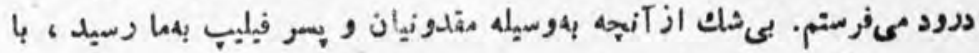

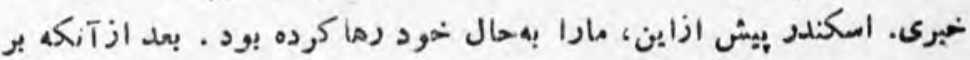

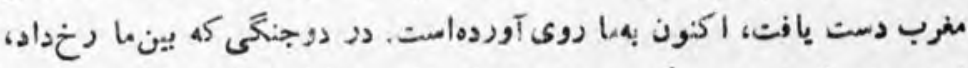

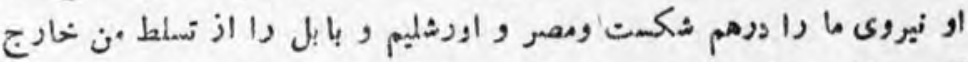

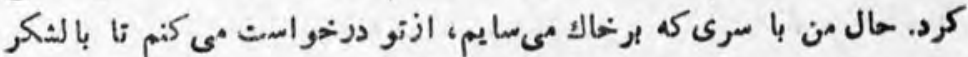

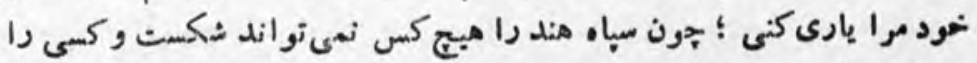

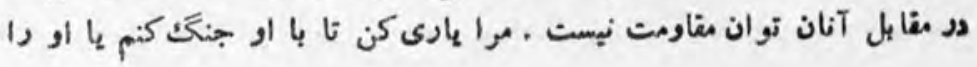




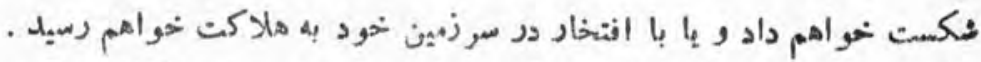

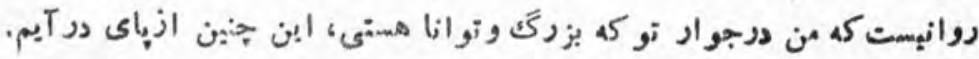

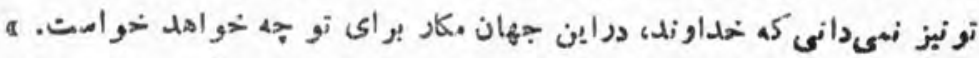

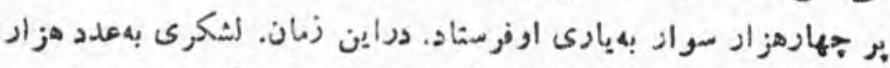

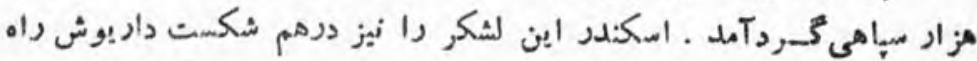

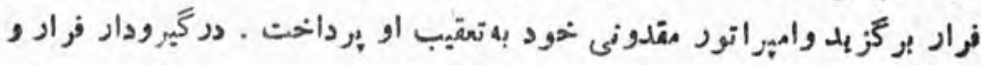

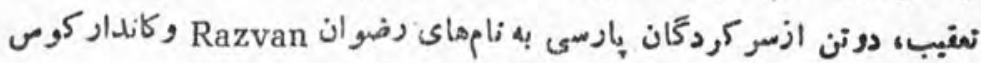

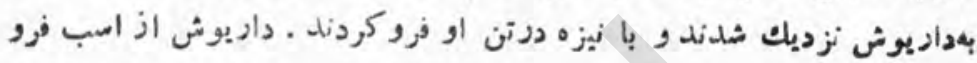

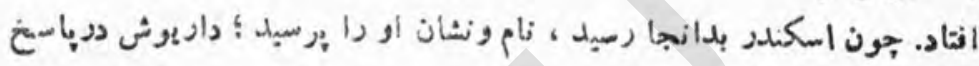
كفت :

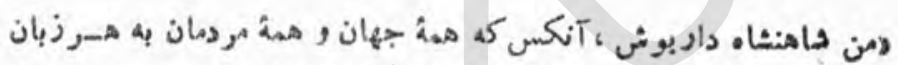

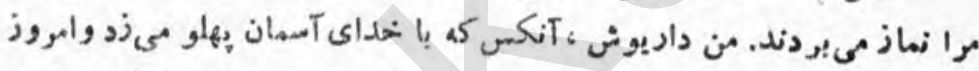

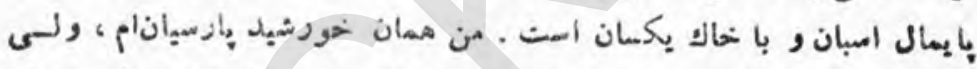

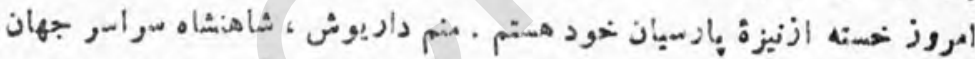

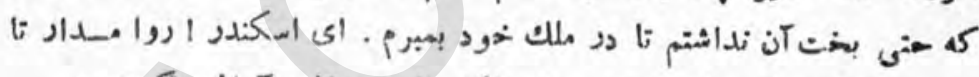

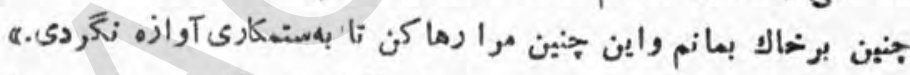

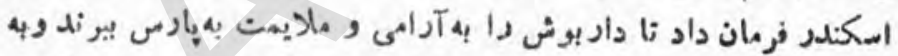

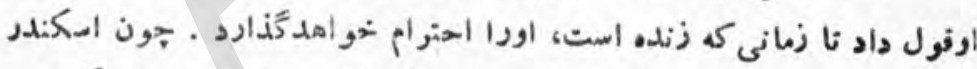

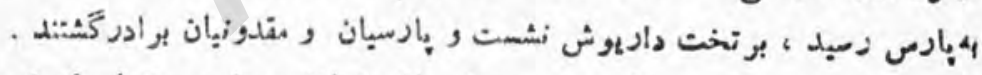

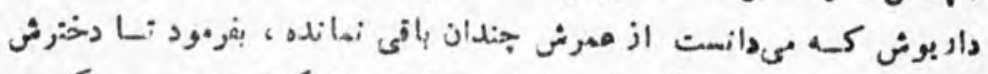

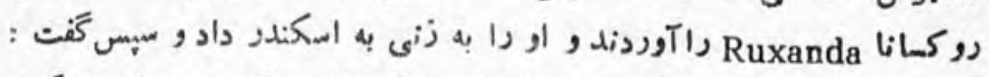

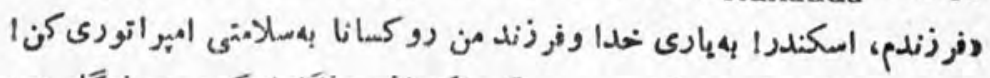

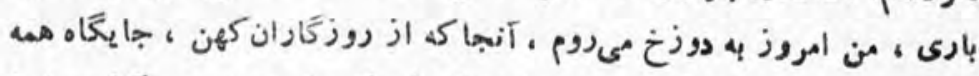

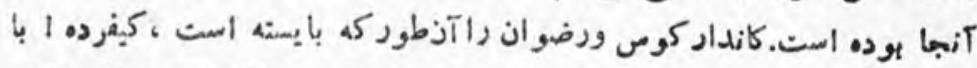

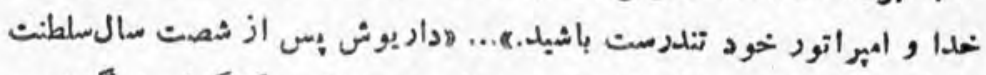

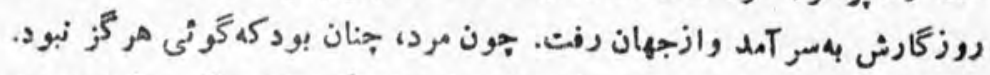

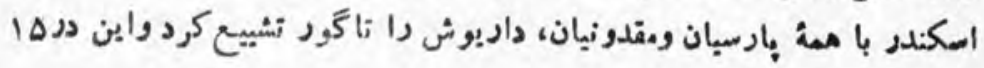
ماه اوت اتفاق افناد.ه 
سنون- Sور \&

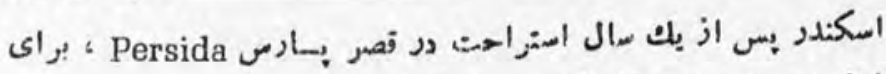

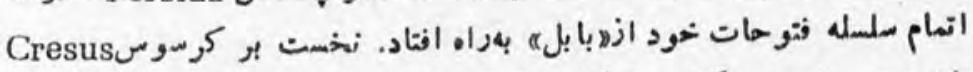

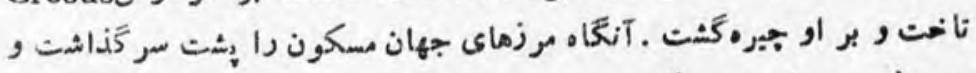

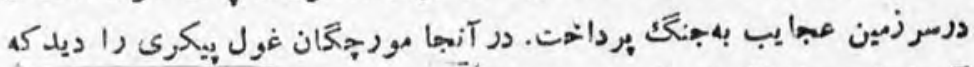

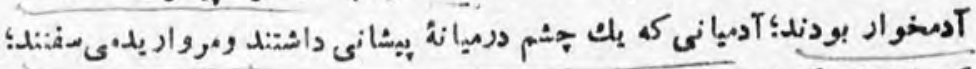

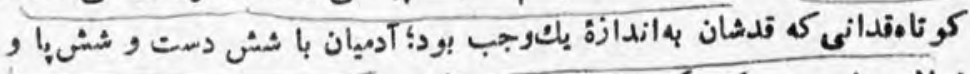

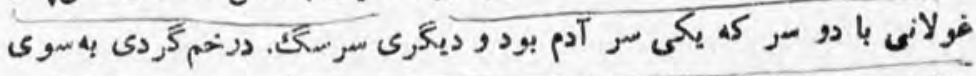

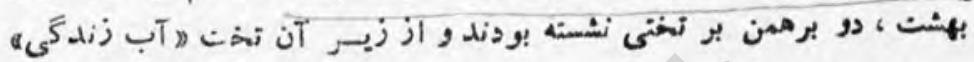

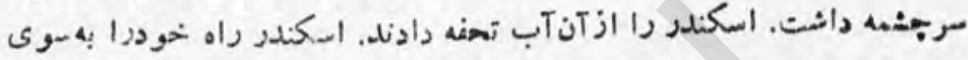

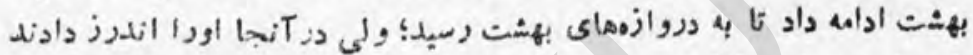

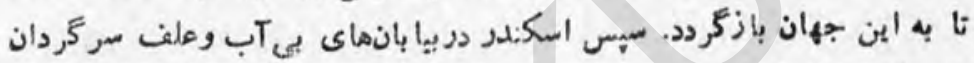

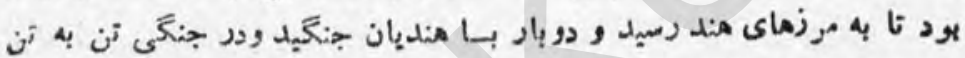

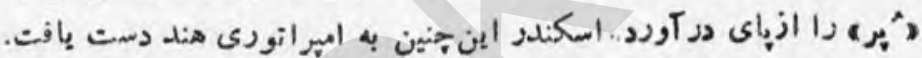

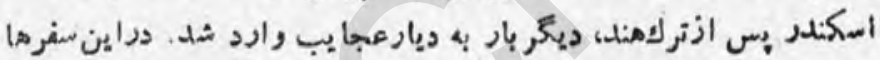

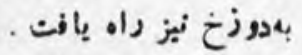

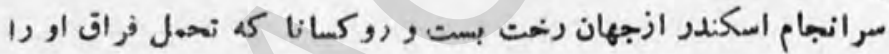
نمىنو انست، خهو درا ملاك كرد.

\section{波海浩}

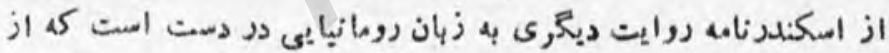

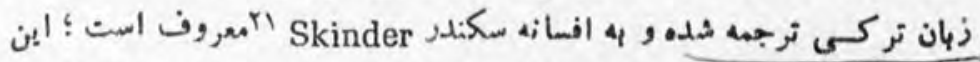

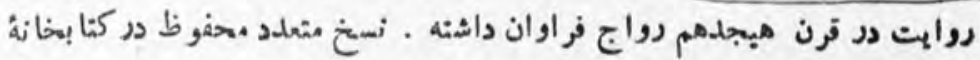

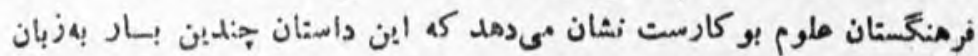

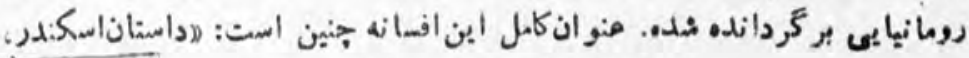

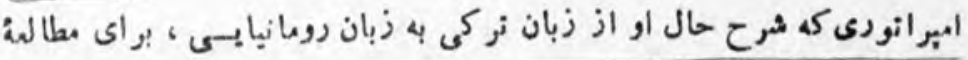

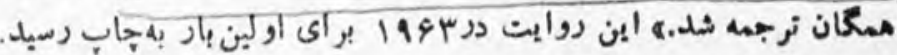

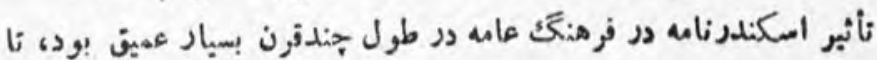

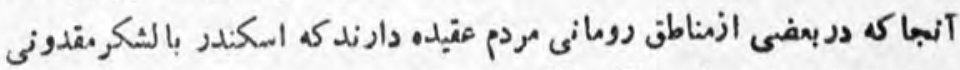

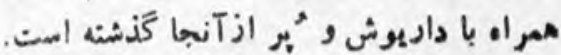




\section{rqq}

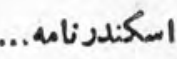

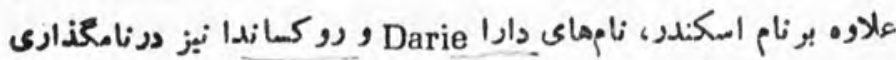

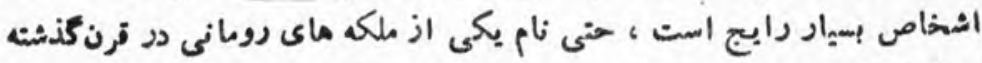
روكساندا بود .

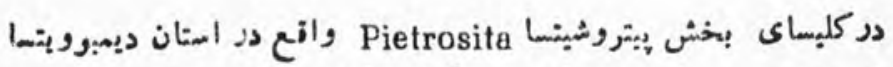
Dimbovita

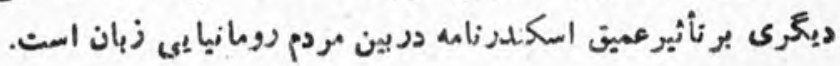

1- I. Chitimia, Cartile populare in literatura roma-

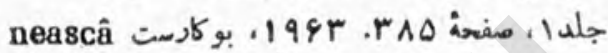

$$
\text { r- }
$$

r_N. Cartojan, Cärtile populare in literatura româ-

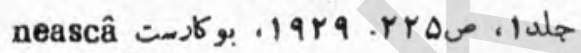

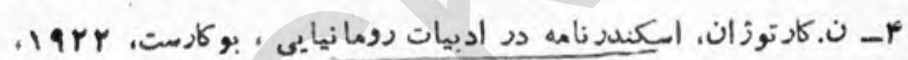

$$
\text { صAN-1l. }
$$

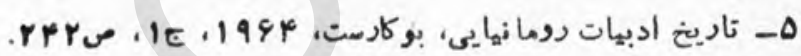

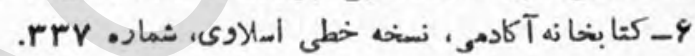

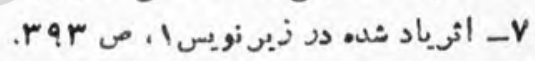

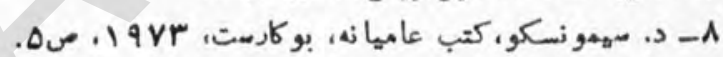

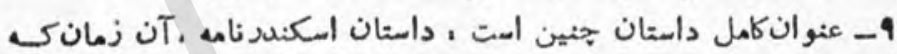

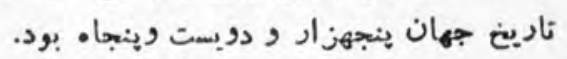

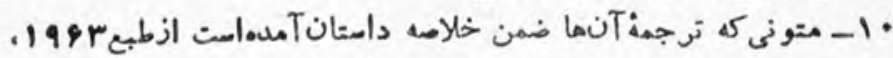

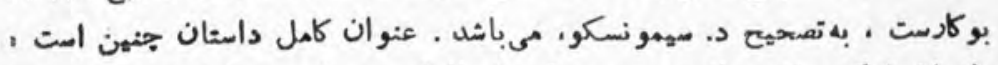

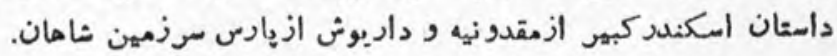

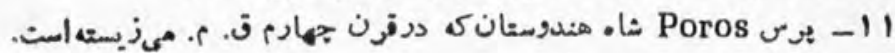

$$
\text { (مادل فورهندى درادبيات فارسى في (1) }
$$

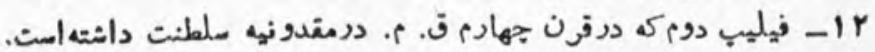

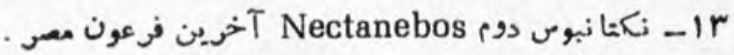

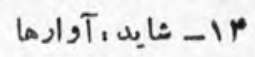

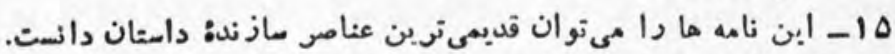
Die Quellen des griechis دران ماند 
Ppigs

rv.

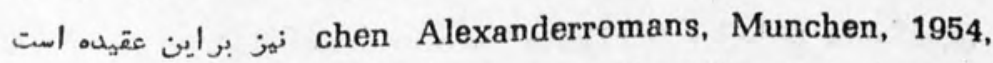

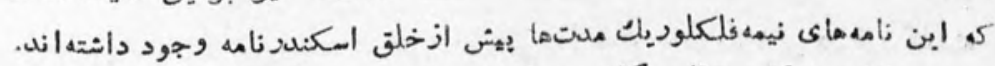

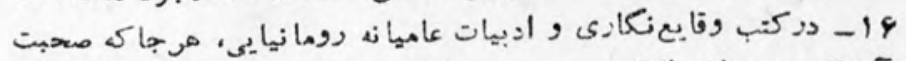

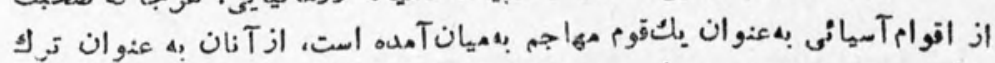

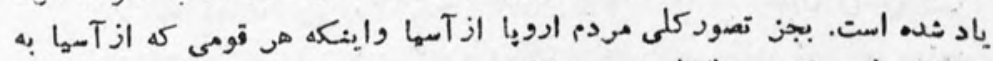

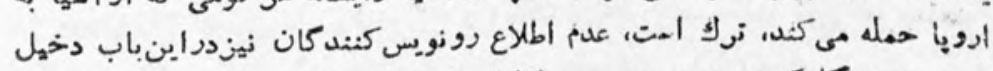

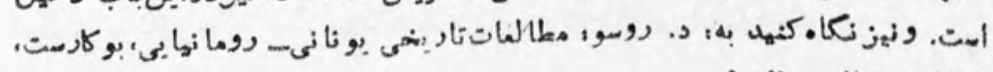
. D. r. re. lara

Pella

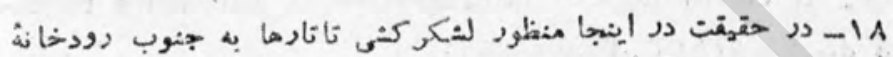

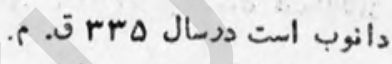

Calinderus 9 . ا

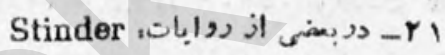




\section{سيرى دو أنبيات معاصر לاين}

\section{r- شعو}

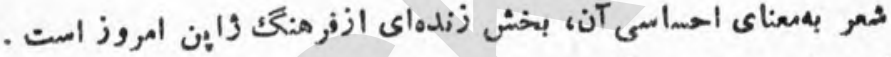

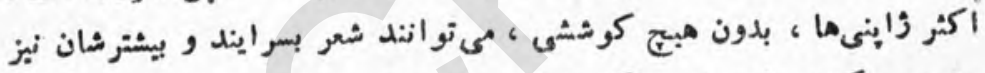

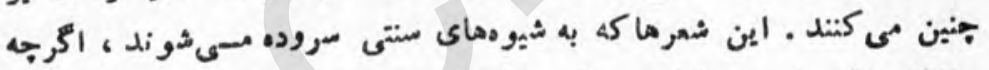

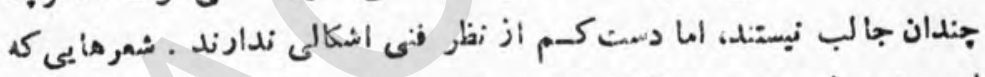

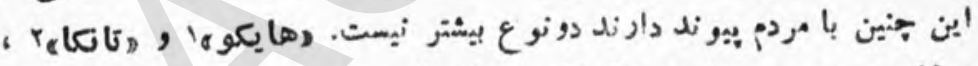

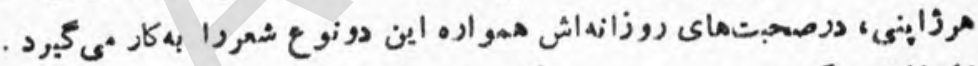

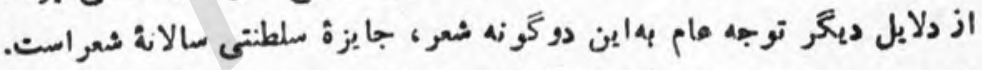

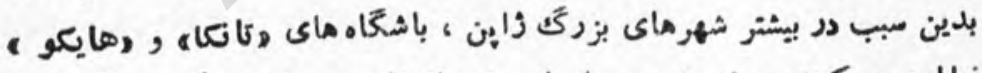

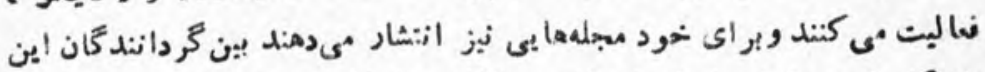

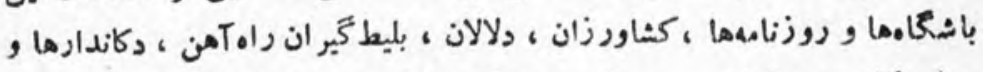

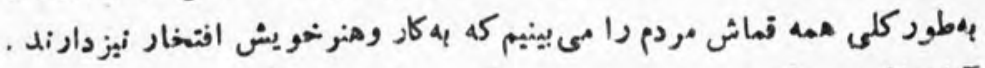

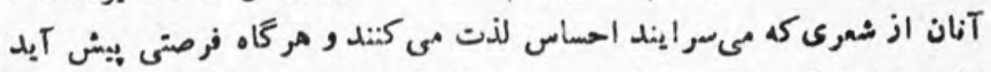

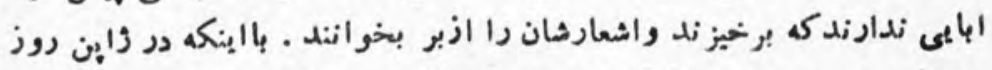

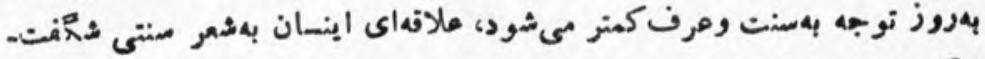

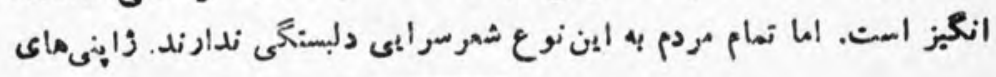

$$
\text { 1- Haiku 2- Tanka }
$$




\section{سخن - دور مps}

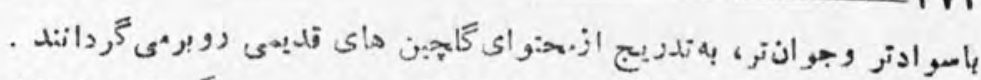

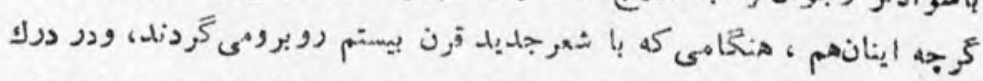

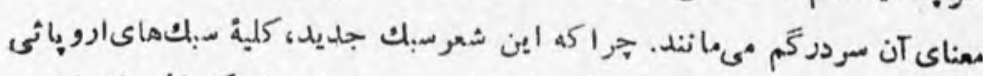

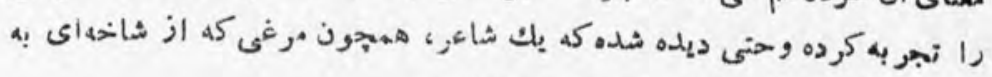

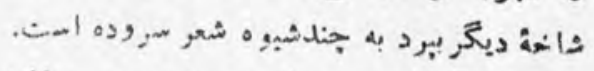

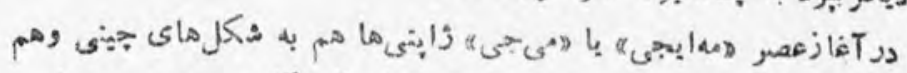

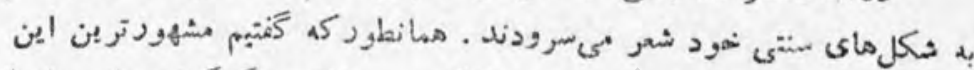

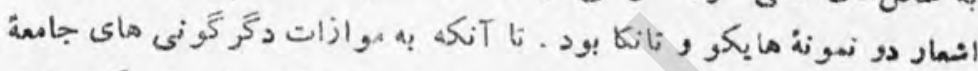

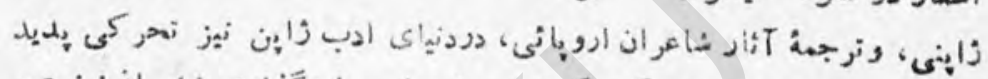

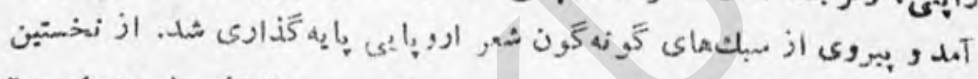

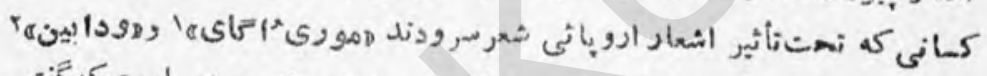

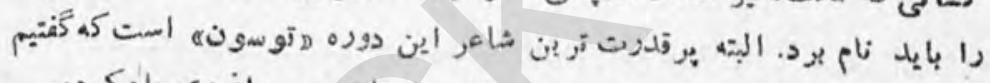

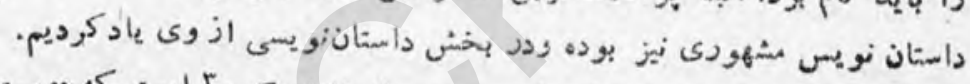

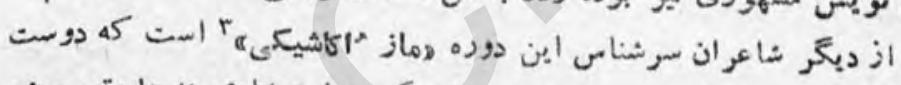

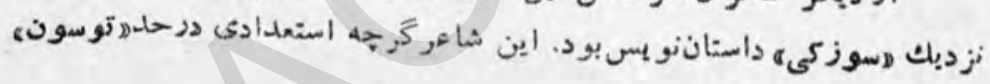

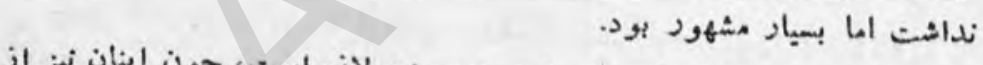

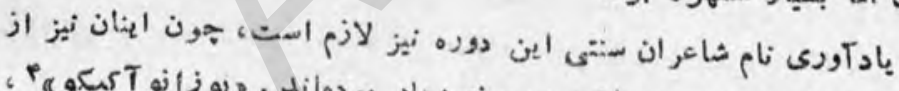

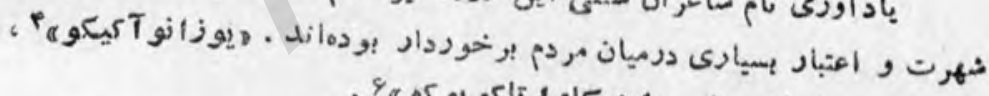

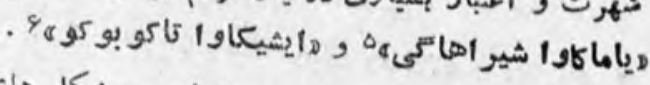

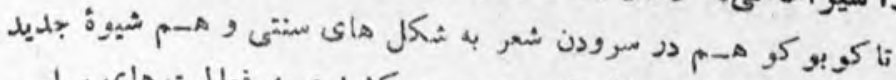

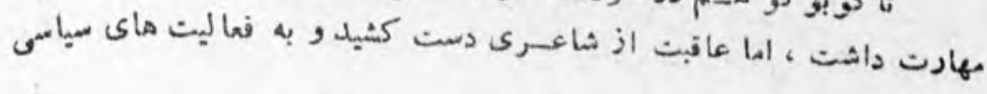
$\therefore$.

1- Mori ogai

2- Veda Bin $\left(1 \wedge \mathrm{Vk}^{6}-1919\right)$

3- Masaoka Shiki $\left(1 \wedge 9 V_{-19 \cdot r)}\right.$

4- Yosano Akiko ( $\wedge \vee \wedge-1 q \uparrow r)$

5- Yamakawa Shirahagi $(1 \wedge \wedge \cdot-19) \cdot)$

8-Ishikawa Takuboku ( $\left(\wedge \wedge \Delta_{-19 \mid \mathrm{r})}\right.$ 


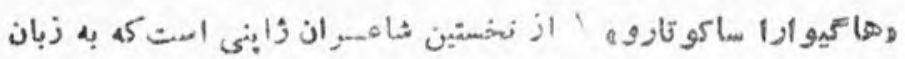

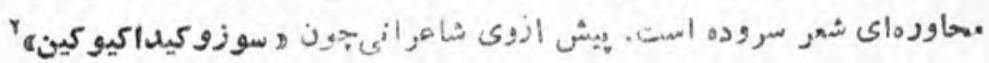

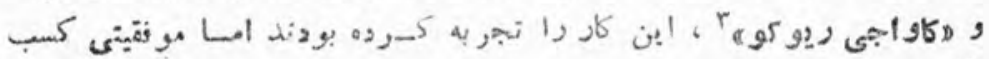
is

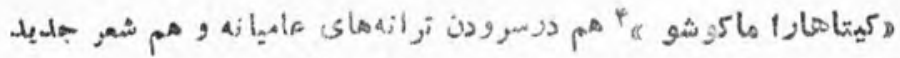

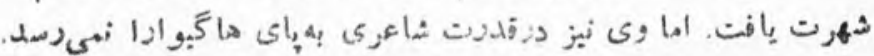

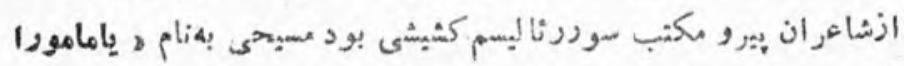

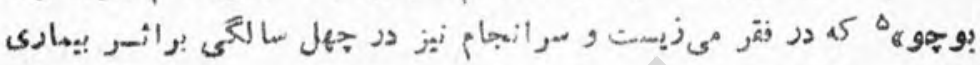

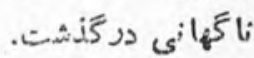

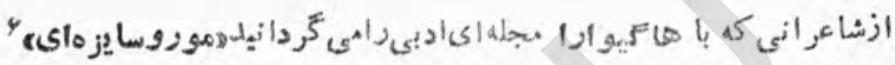

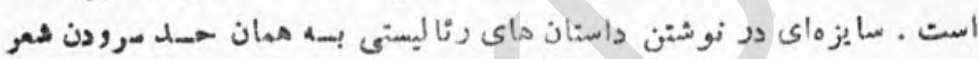

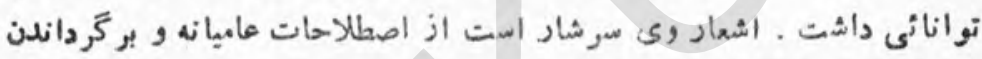

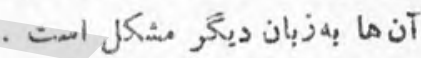

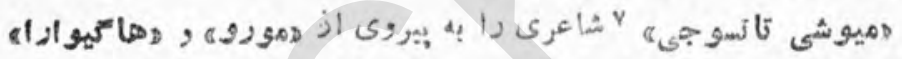

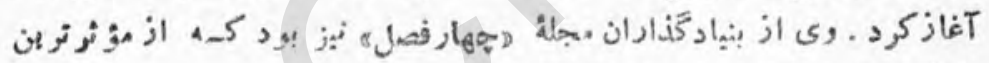

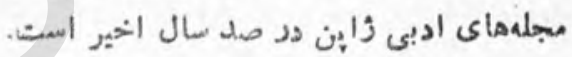

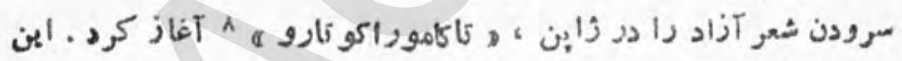

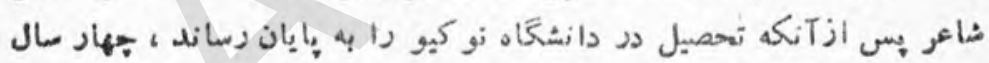

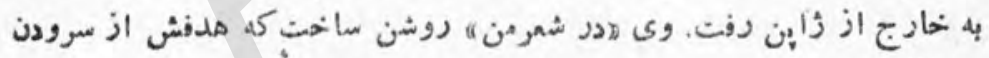

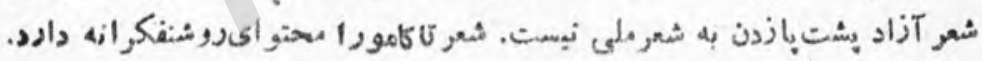

1- Hagiwara Sakutaro ( $1 \wedge \wedge 9-19 \uparrow r)$

2. Susukida Kyukin

3. Kawaji Ryuko

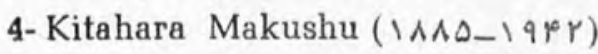

5- Yamamura Bocho ( $|\wedge \wedge p-| q Y p)$

6- Moro Saisei ( $\ \wedge \wedge q-1 q ८ \curlyvee)$

7-Miyoshi tatsuji (19*-199\%)

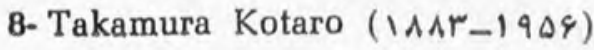


מور\& rYP

تنها داعرهاى كه درسبك جديد ثهرت دارد رفوكاءُسو ماكوع' است .

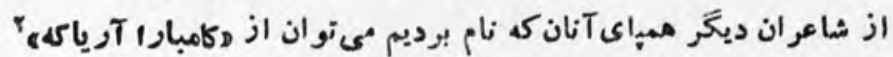

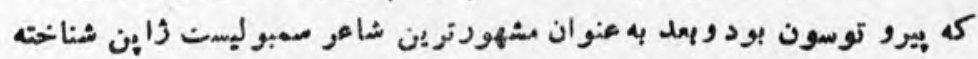

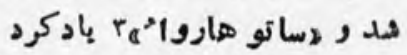

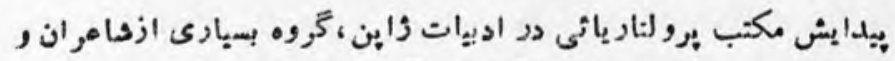

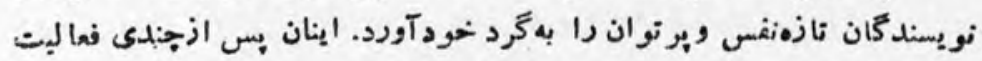

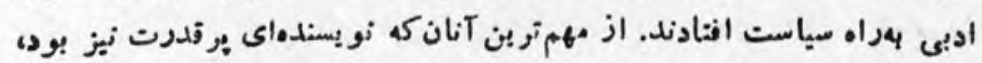

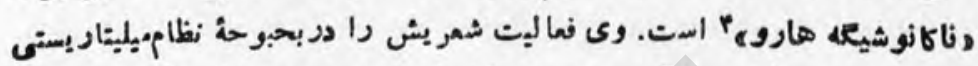

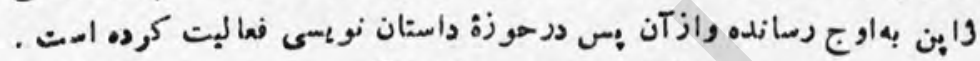

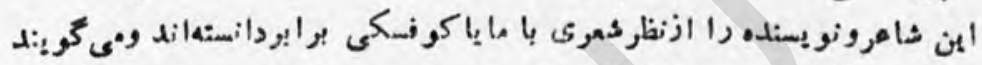

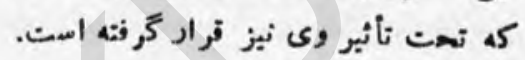

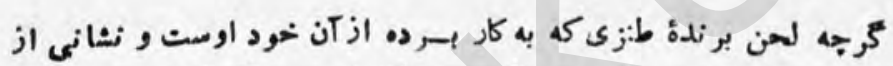

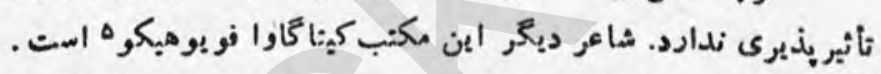

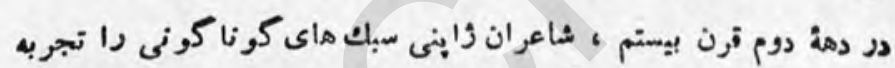

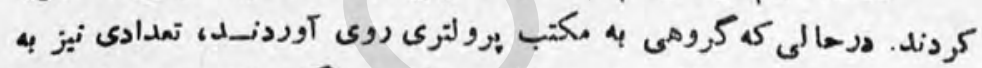

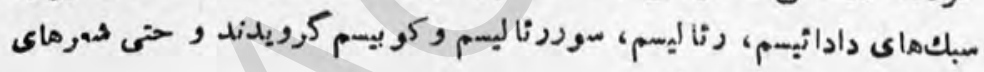

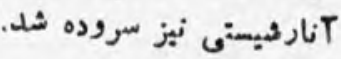

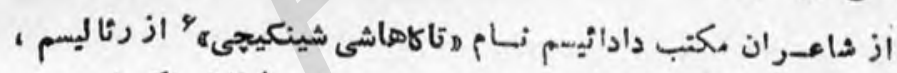

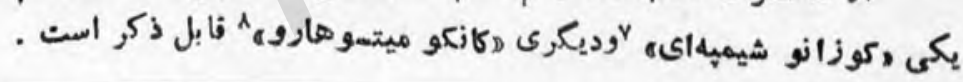

1- Fukao Sumako (1^४r)

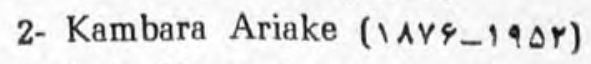

3- Sato Haruo ( $\left.1 \wedge 9 r_{-1} \uparrow 4 \uparrow\right)$

4- Nakano Shigeharu $(19 \cdot r)$

5- Kitagawa Fuyuhiko

6- Takahashi Shinkichi

7. Kusano Shimpei $(19 \cdot r)$

8- Kaneko Mitsuharu 
rvo

ميرى در - مي

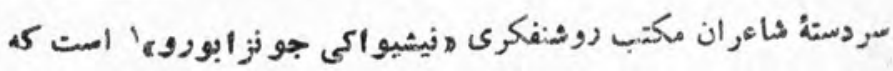

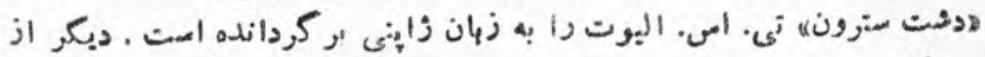

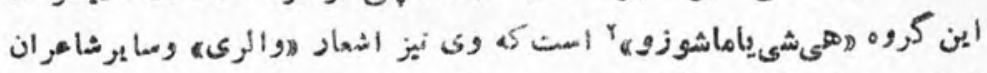

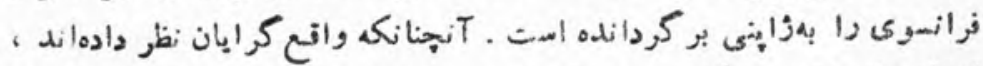

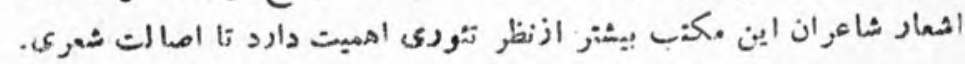

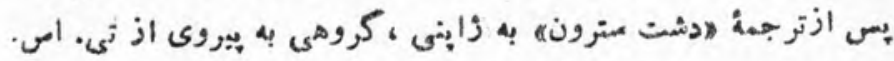

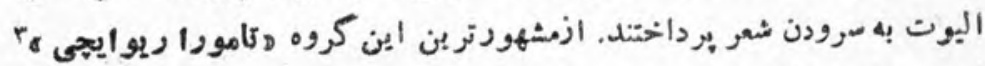

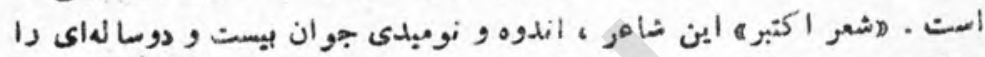

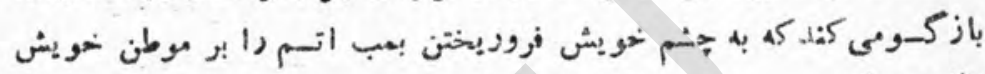

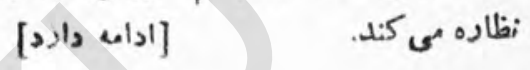

سه ها هبكو

$$
\begin{aligned}
& \text { مرغان دريانى زمستان } \\
& \text { در زندكى لانه ندارند . }
\end{aligned}
$$

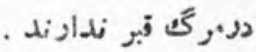

كاتوشوسون

Kato Shuson

$$
\begin{aligned}
& \text { در ورفاى شملهما }
\end{aligned}
$$

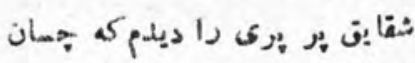

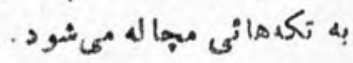

كاتوشوسون

$$
\begin{aligned}
& \text { هشفانكيز و ديدنى : } \\
& \text { از سوراخ زئجرة كاغذى ودئ } \\
& \text { كأ }
\end{aligned}
$$

$$
\text { كوبإياشى إيا }
$$

Kobayashi Issa

1- Nishiwaki Junzaburo ( $1 \wedge 9 \uparrow)$

2- Hishiyama Shuzo (19-9)

3. Tamura Ryuichi (19rr) 
مخن sورة

\section{كيتاتاوا فويوهيكو}

$$
\text { بهار بيش رس }
$$

$$
\text { نارمانى آمبخته با برف باربل، }
$$

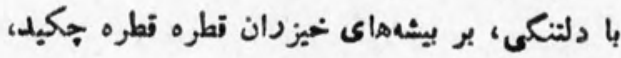

$$
\begin{aligned}
& \text { در رؤا به قلب ديكرى انداشيدم، } \\
& \text { و هنامى كه بيدار تمديم }
\end{aligned}
$$

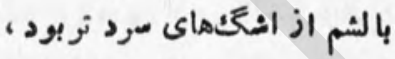

$$
\begin{aligned}
& \text { برمر قلب من جهاTمده ؟ }
\end{aligned}
$$

خوردبد ازينمبرههاى بلند 4 ملايمت مىدرخشيل ،

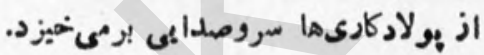

$$
\text { ازبستر بيرون مى بـ }
$$

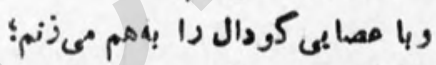

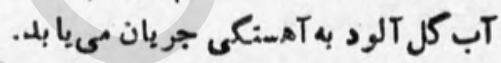

مارمولكى خرد، خودرا به جوانان آب تسليم مى كند.

$$
\text { در مزارع }
$$

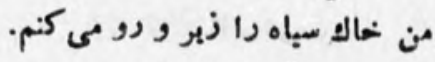

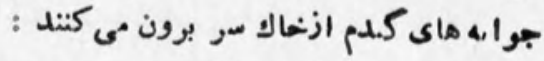

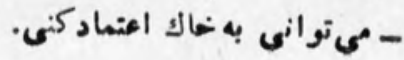

توجهג م. سجودى 


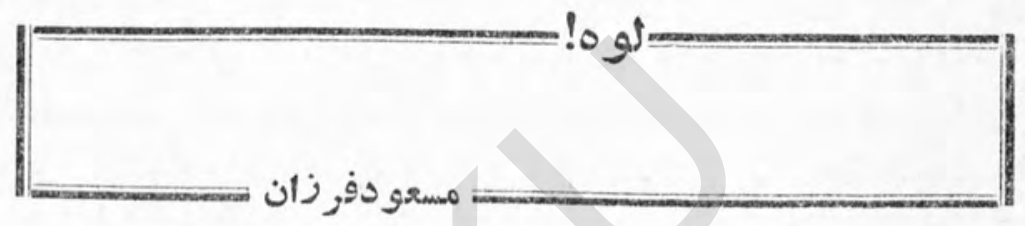

داستان كو تاه 》لوه) كه نخستين بار در شهـاره رائيز سال

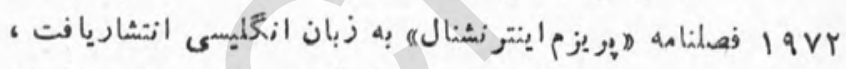

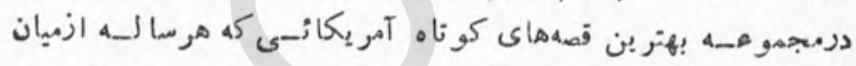

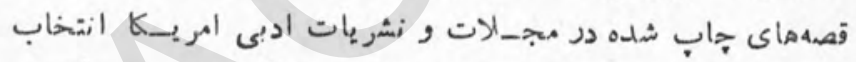

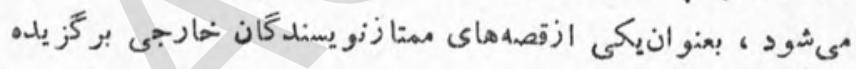
شده است . شتود

مسهو د فرزان كه سا لها استاد دانشًُاه كلمبيا وكاليفر نيا بوده.

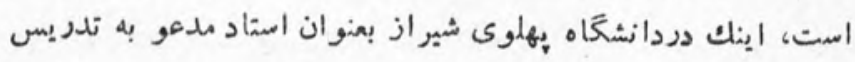
اشتخال دارد.

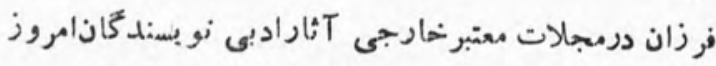

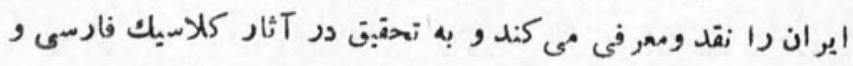

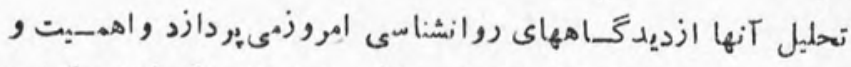

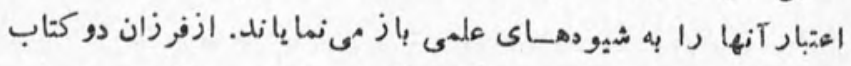

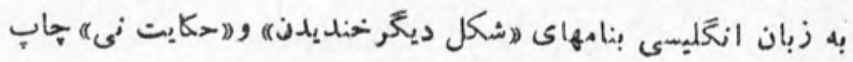

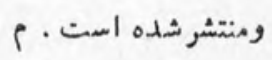




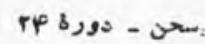

در قسهت ميوه وسبز يجات فروشى يك سوبرثماركت درهاروتتاناه بود

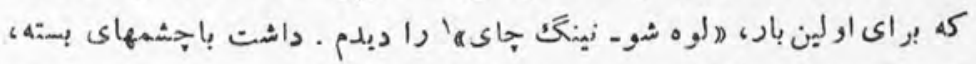

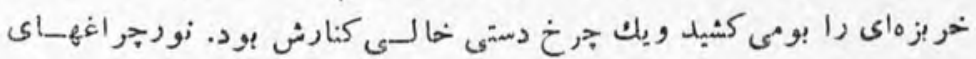

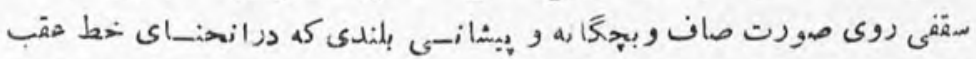

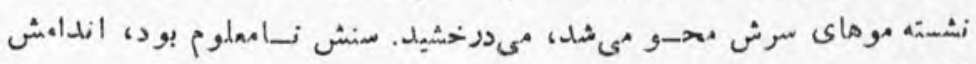
. 412,5

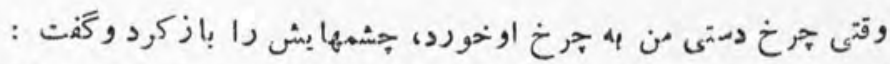

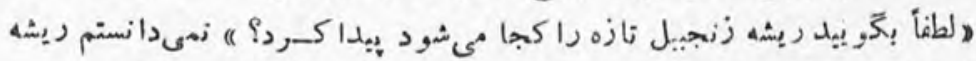

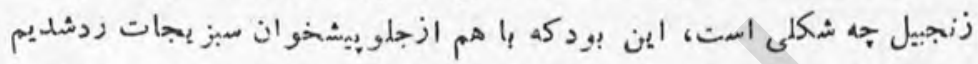

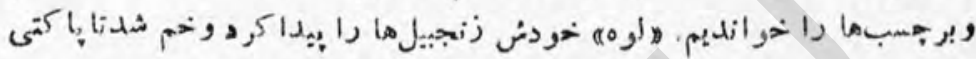

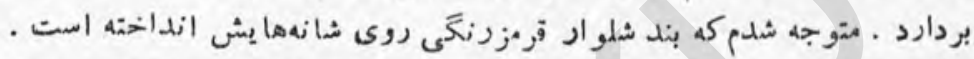

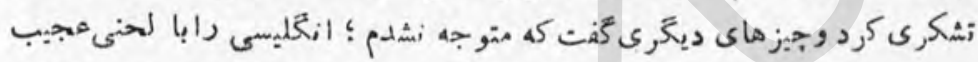

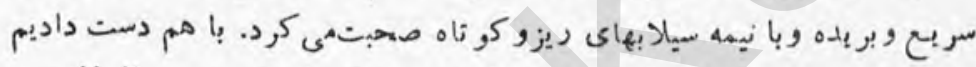

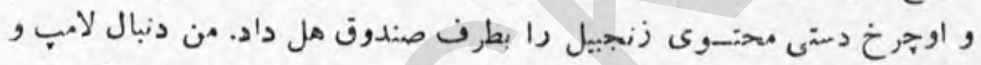

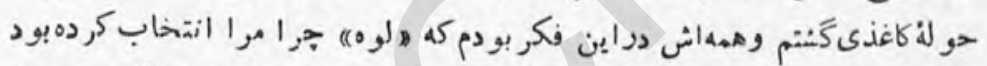

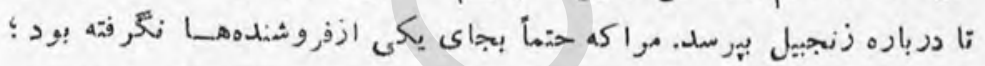

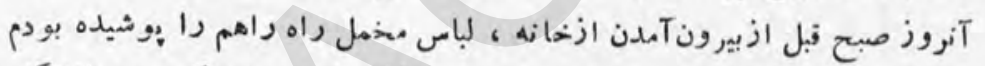

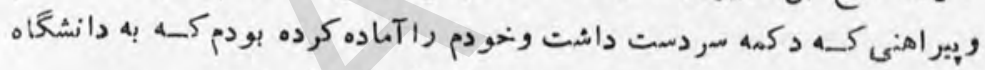
بروم ودكترهجرج تامسه دئيس بخش علوم انسانىرا بينم.

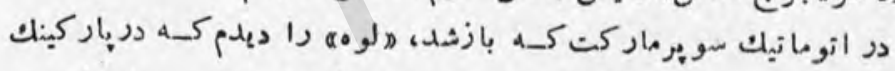

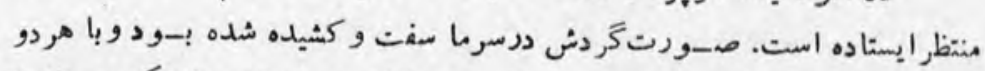

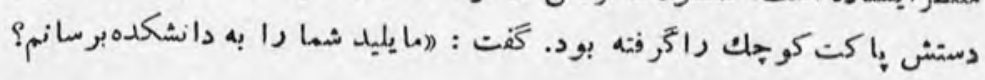

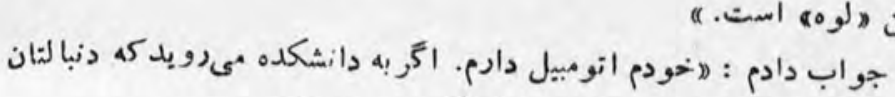

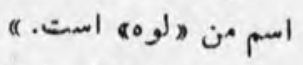

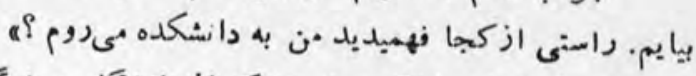

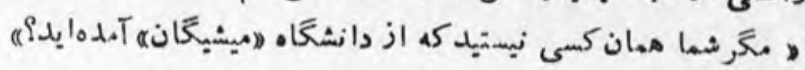

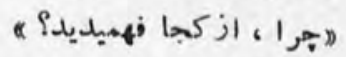

1- Loh Shu - Ning Tsai 


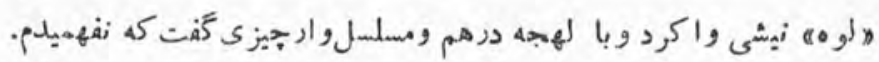

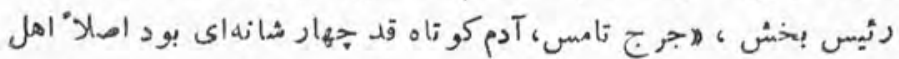

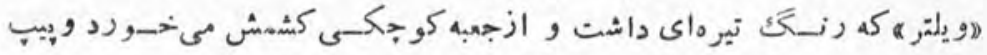

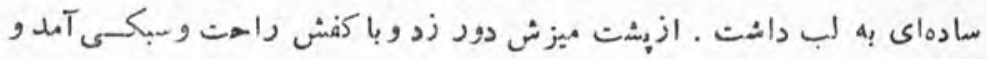

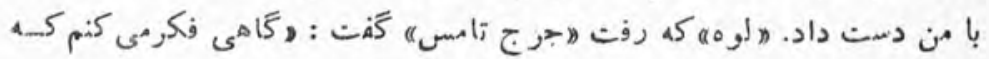

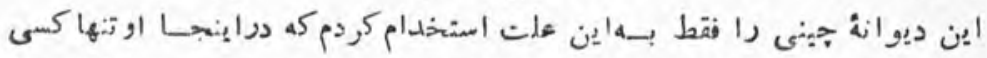

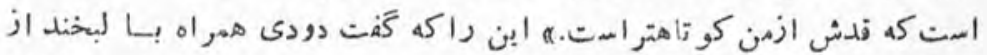

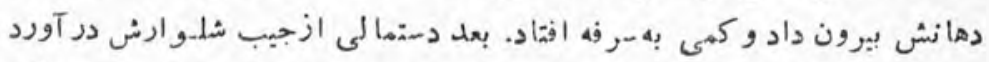

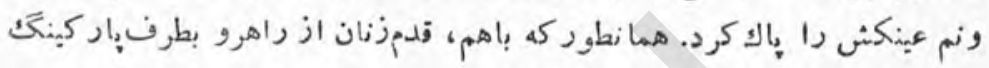

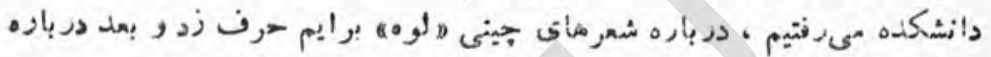

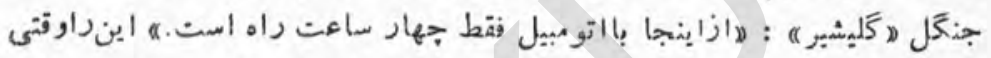

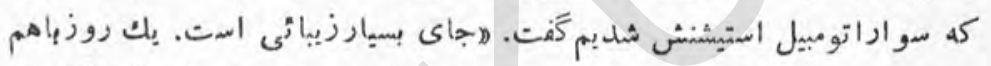

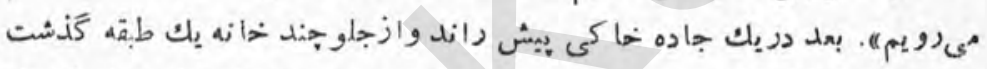

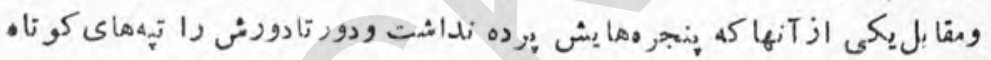

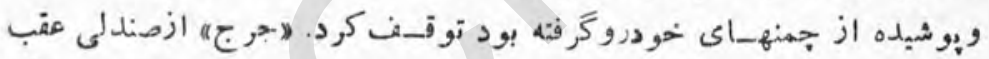

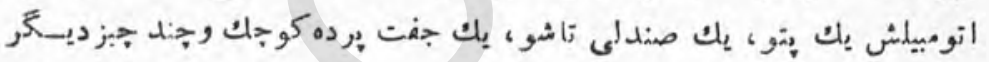
بيرونآورد وآنها را به داخل خانه خا لى برد. بعد قدم زنان به دانشكانده رفت

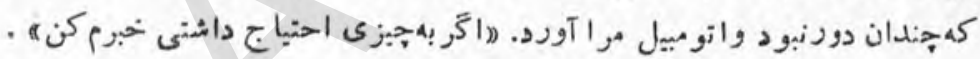
•

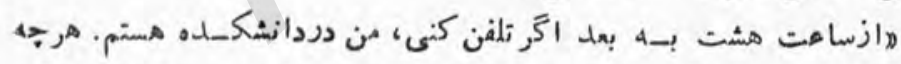

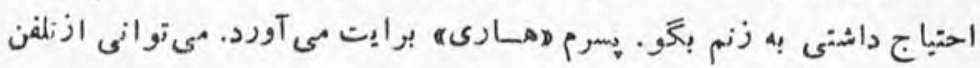

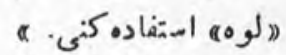

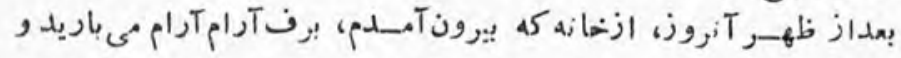

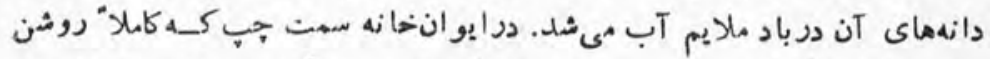

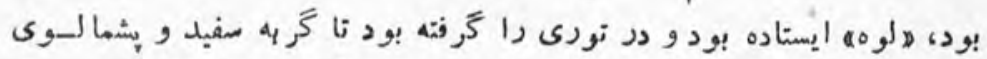

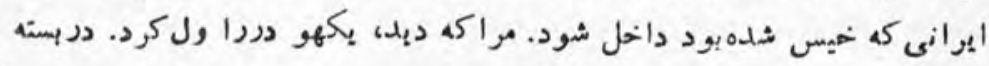

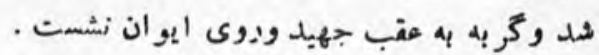

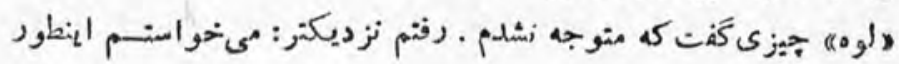




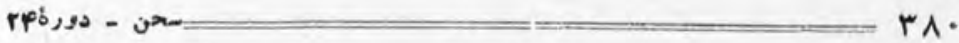

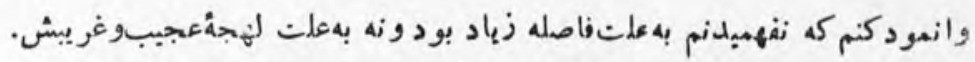

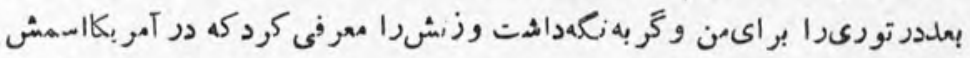
را راشانه كذاشته بودنل ورو بروى تلو يز يون نشسته بود و برنامه هادور بين درميان

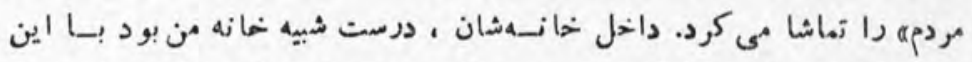

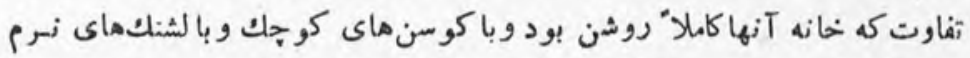
ورو كثهاى صندلى وبشتىهاى كنارديو ار كه همه دستباف بود، حالتيا كيزه

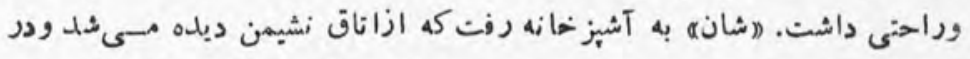

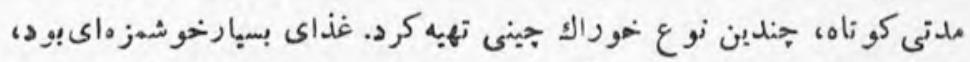

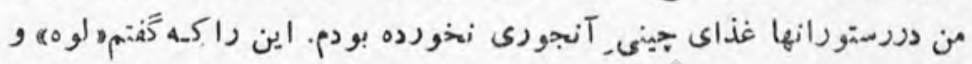

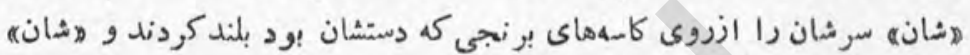

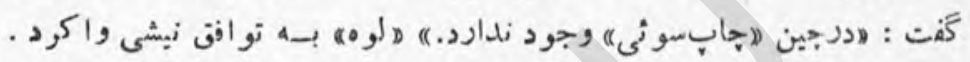

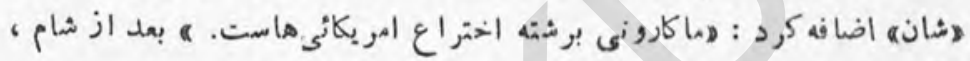

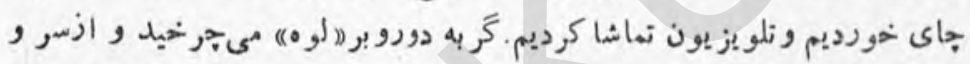

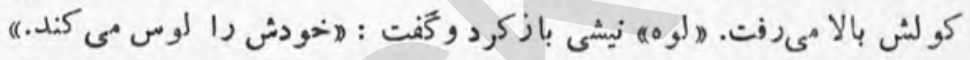

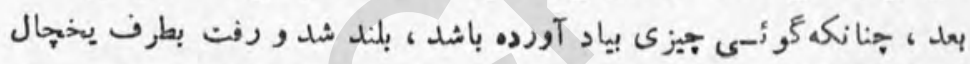

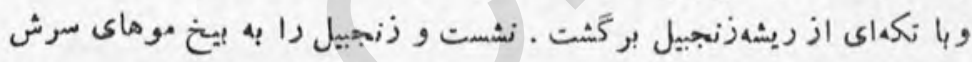

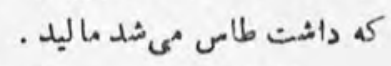

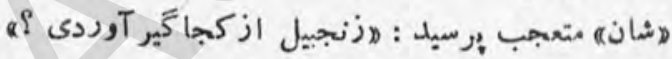

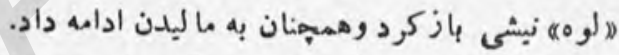

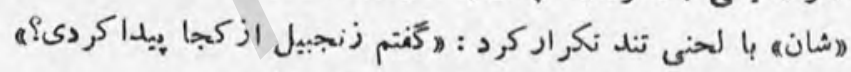

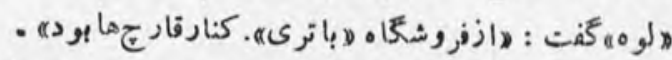

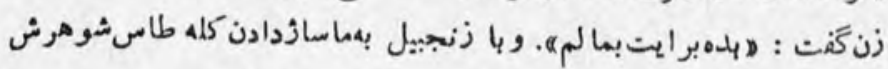
.

\section{$-r-$}

كلاسها زودشروع عشد. شبها، (الومه وزنش مرابه جاى دعوتمى كردند

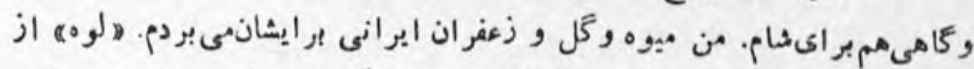

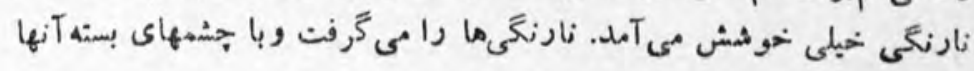




$$
\text { را بومى كشيد ومى كَفت : }
$$

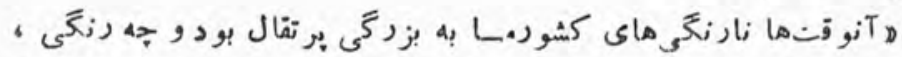

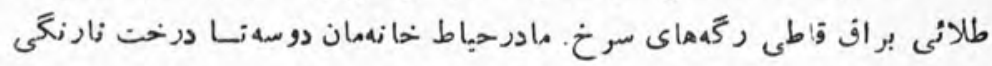

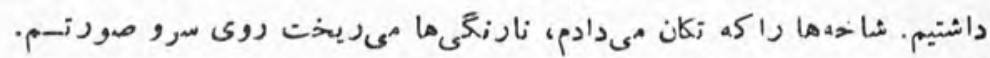

$$
\text { جه كيفى داثت }
$$

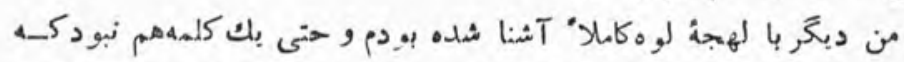

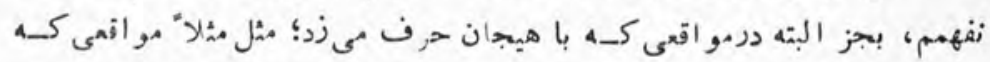

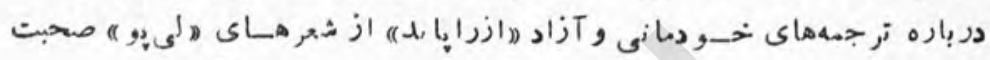

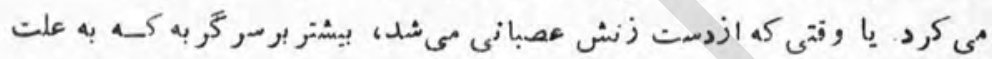

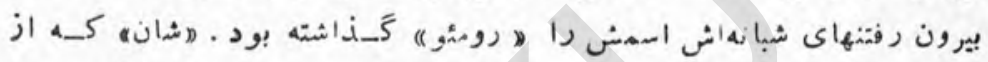

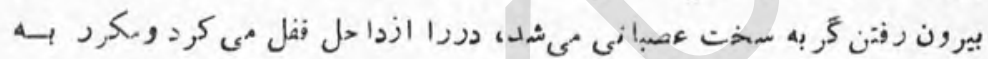

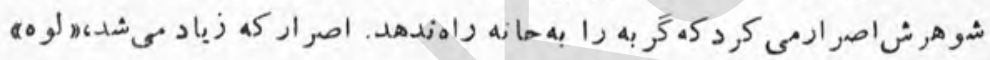

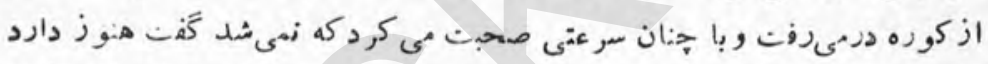

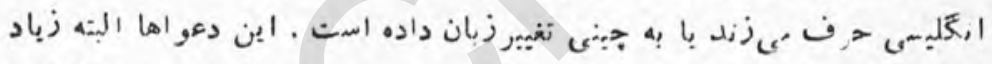

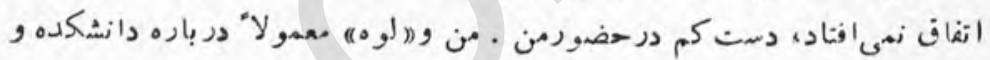

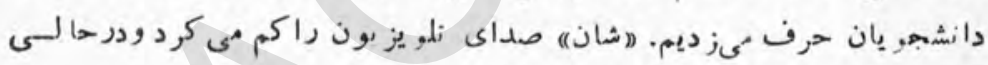

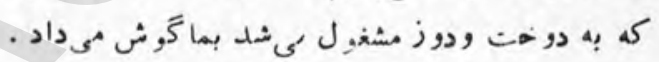

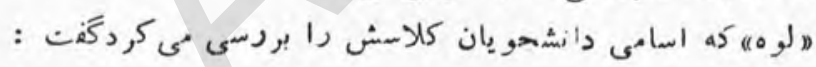

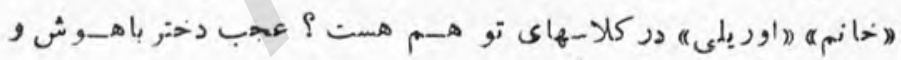

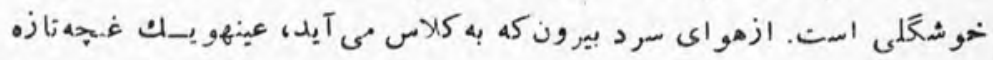

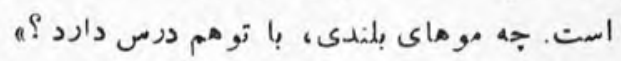

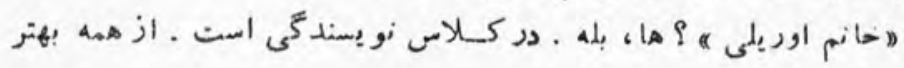

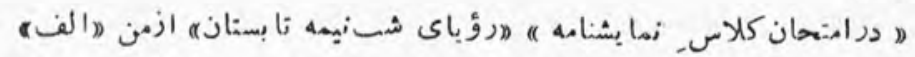

$$
\text { ه. }
$$

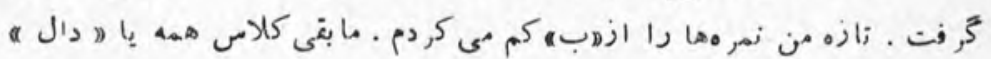

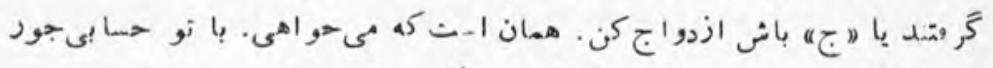

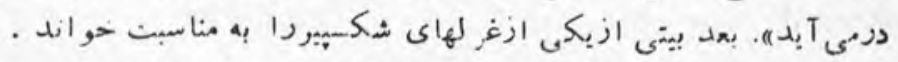

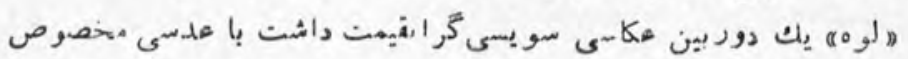


براى كرفتن ازراه دور. بعد ازظهر روزهاى يكثنبه كه با اتومبيل مى رفتيم كنار

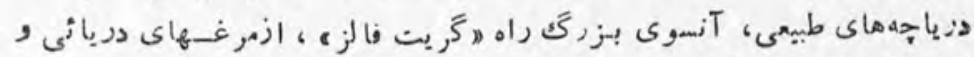

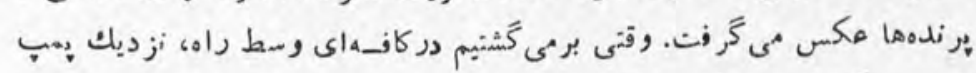

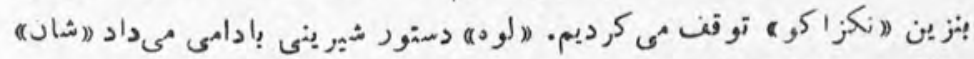

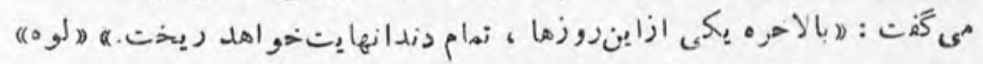

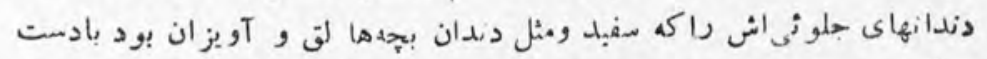

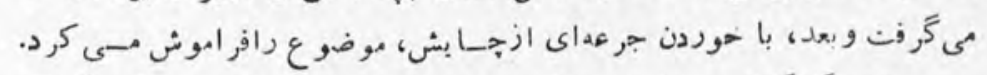

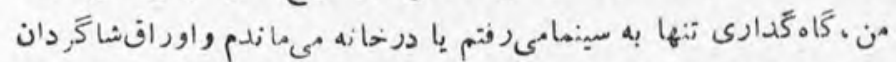

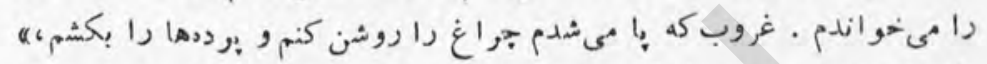

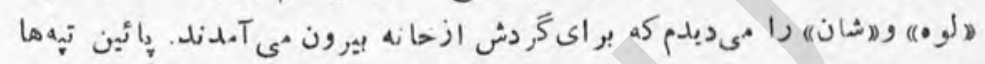

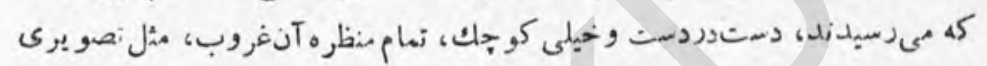

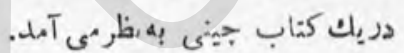

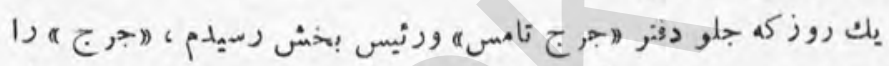

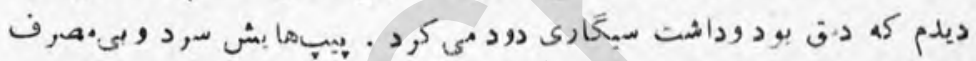

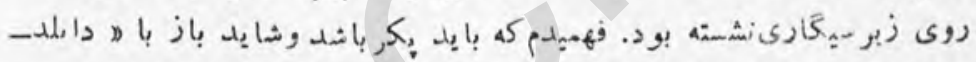

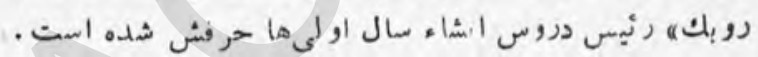

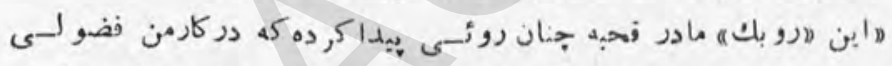

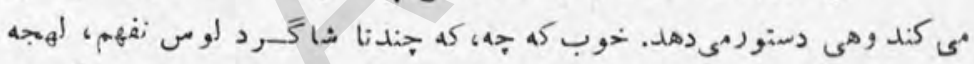

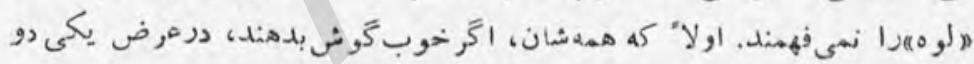

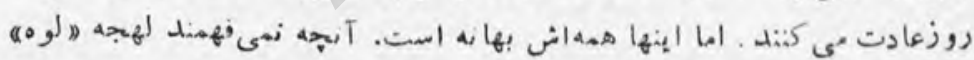

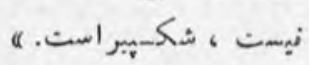

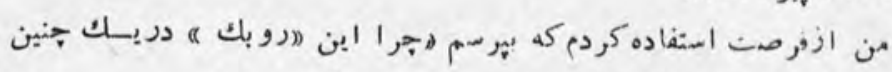

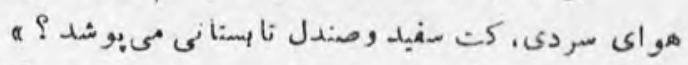

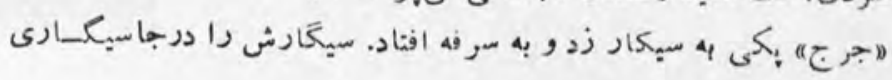

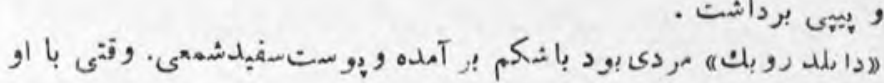

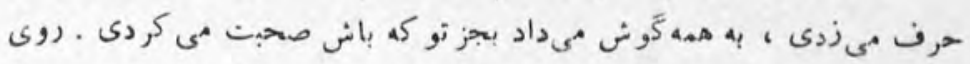

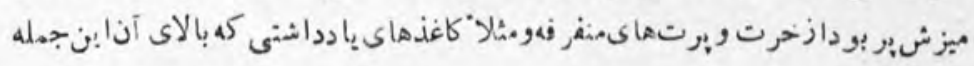


rAr

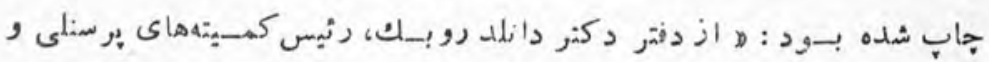

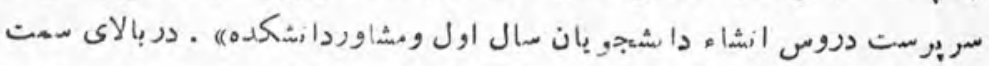

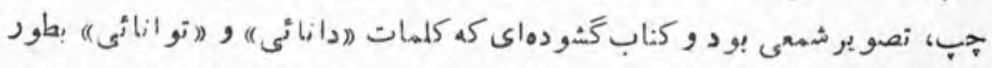

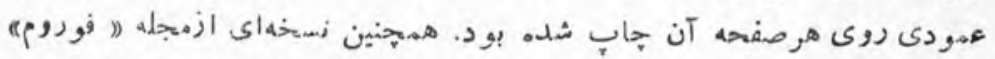

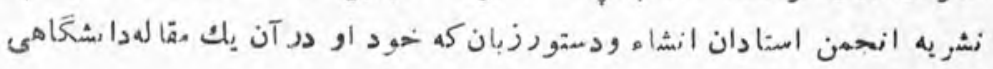

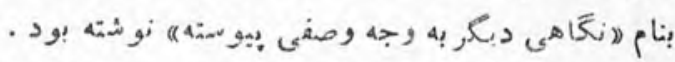

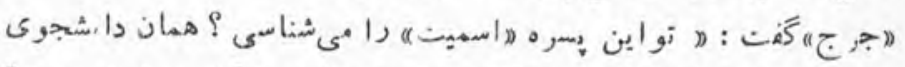

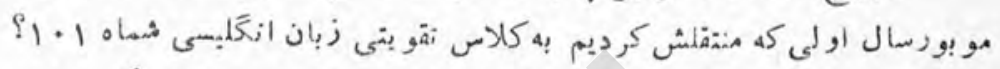

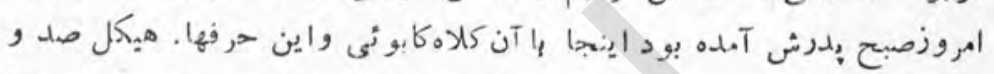

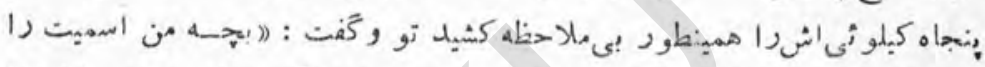

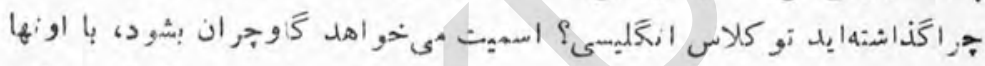

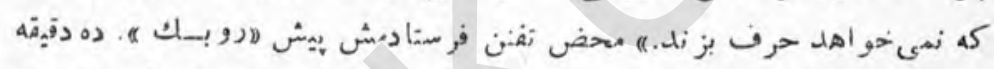

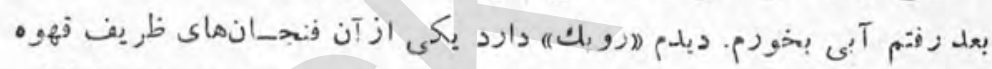

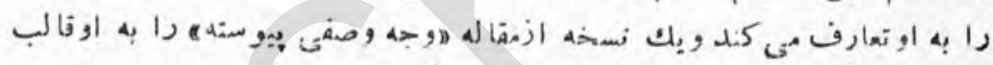
a.

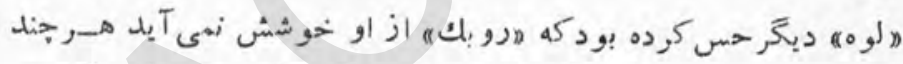

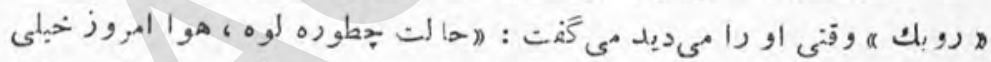

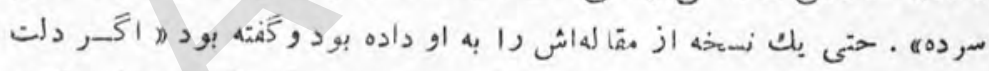

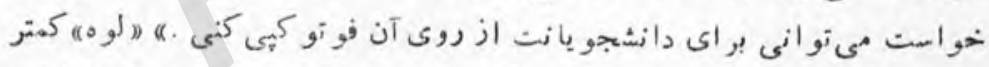

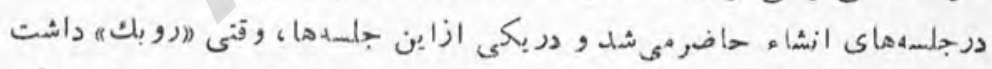

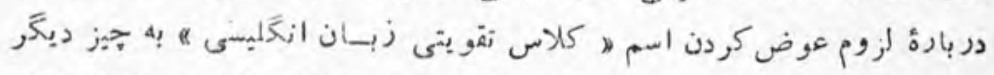

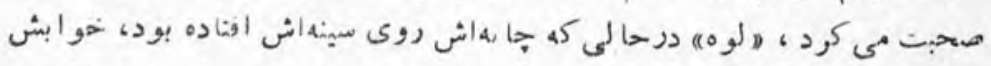

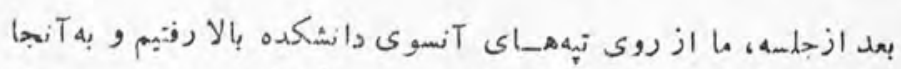
برد .

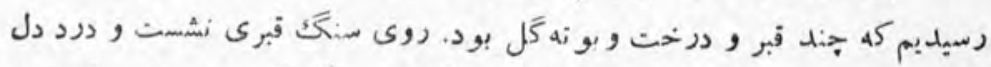

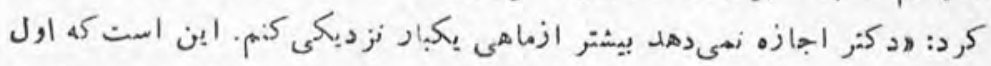

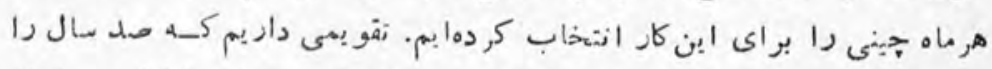

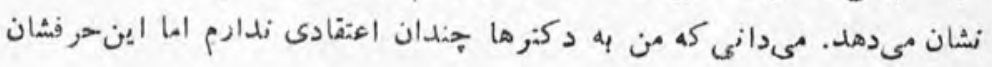




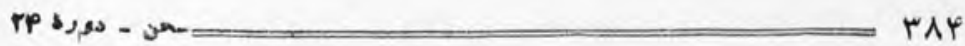

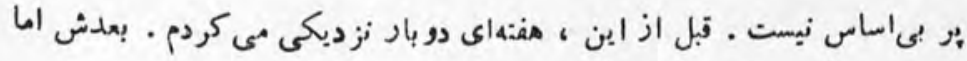

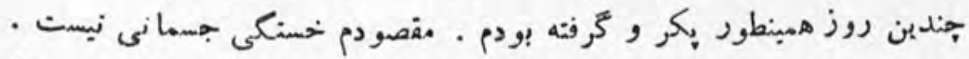

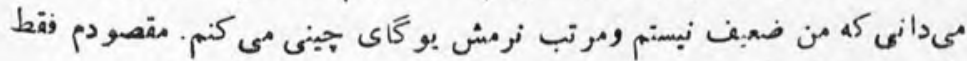

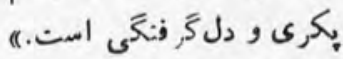

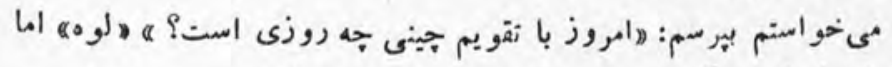

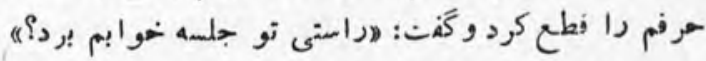

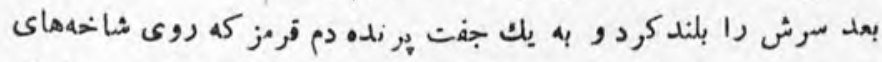

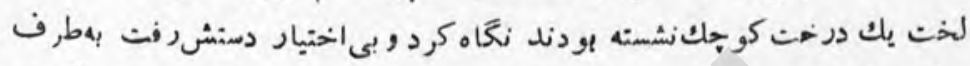

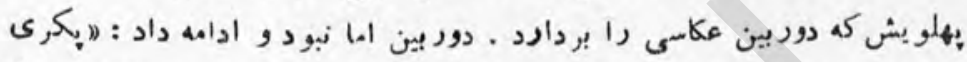

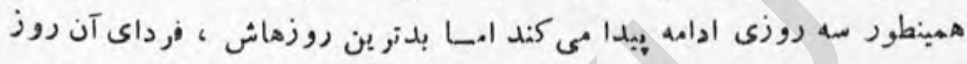

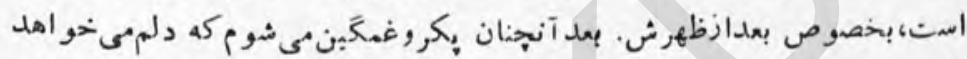

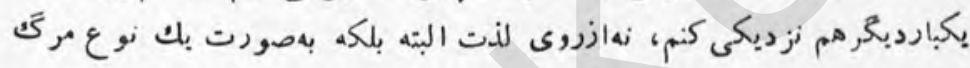

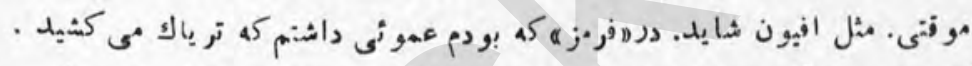

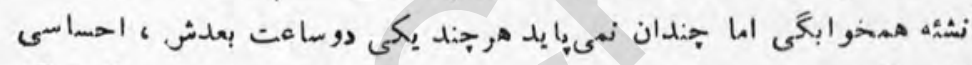

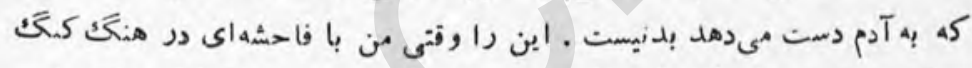

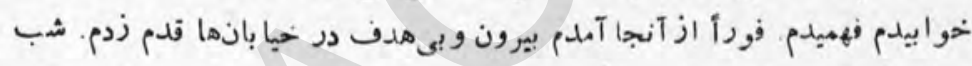

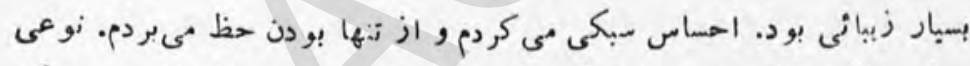

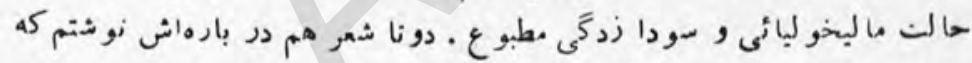

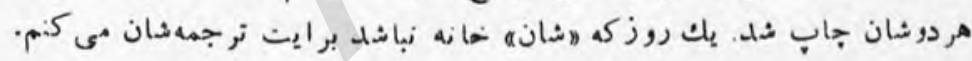

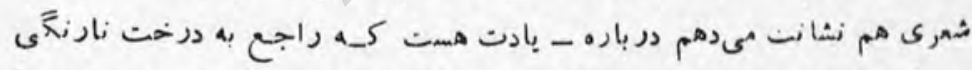

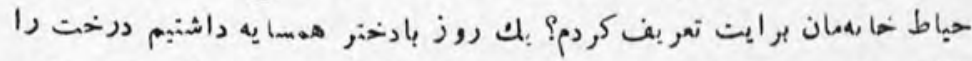

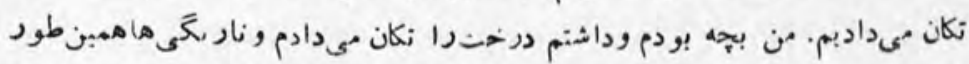

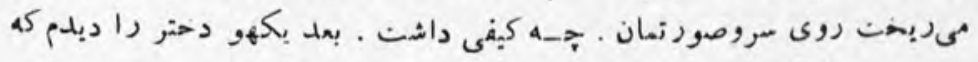

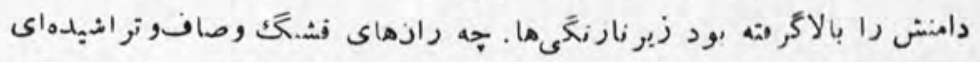

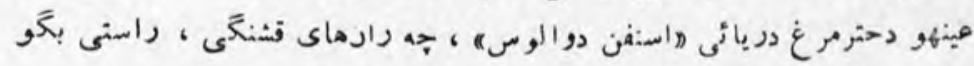

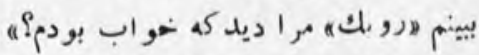

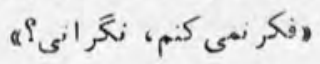

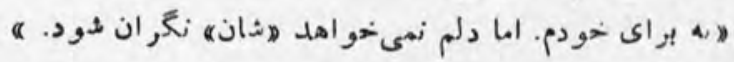




\section{-r-}

زمستان با برف سنگ

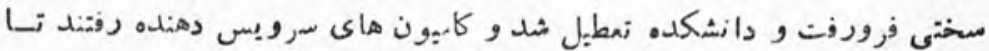

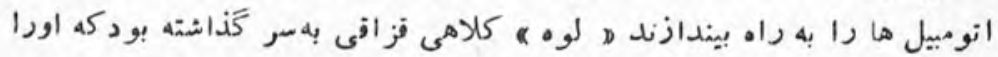

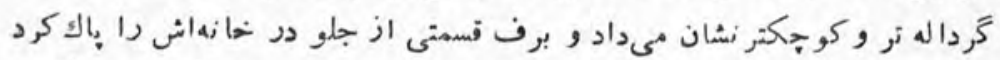

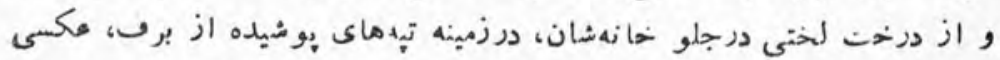

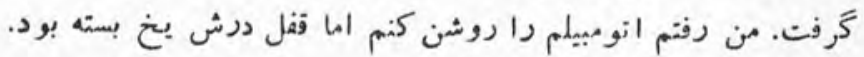

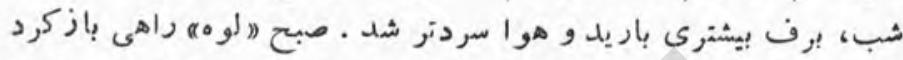

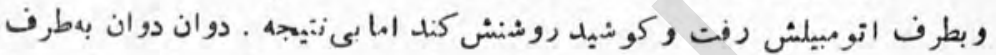

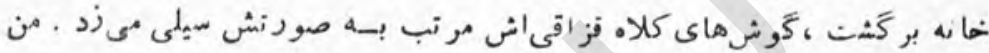

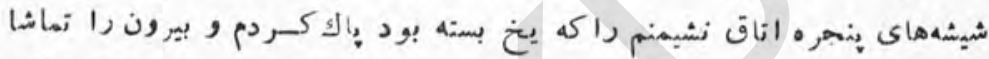

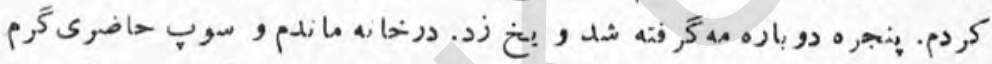

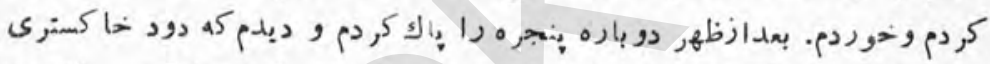

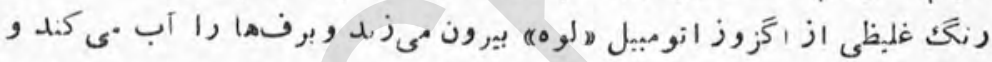

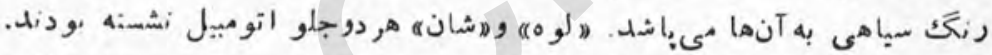

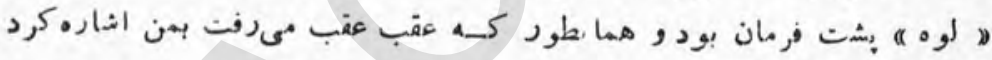

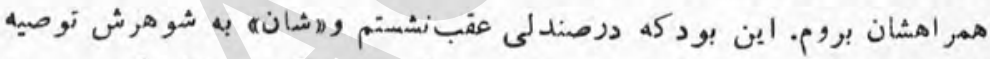

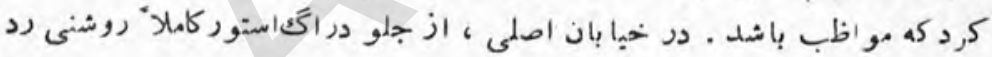

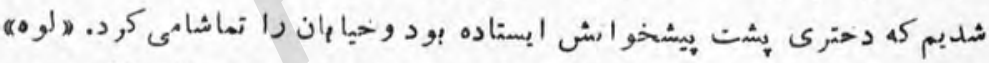

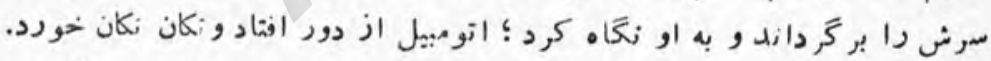

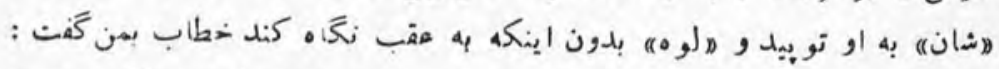

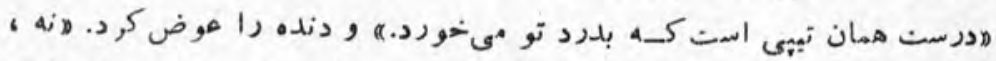

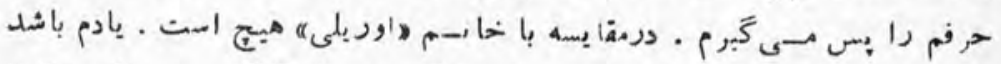

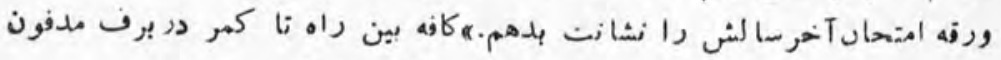

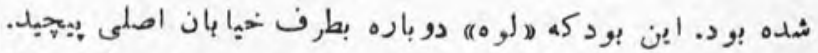

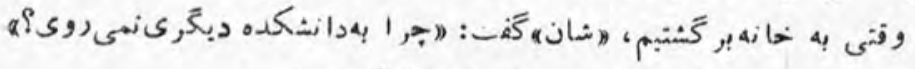

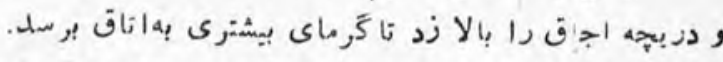

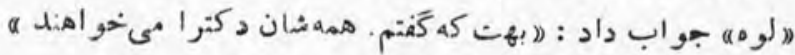




\section{Tf}

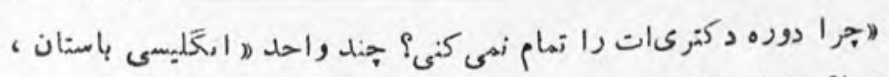
كه بيشتر باقى iمانده

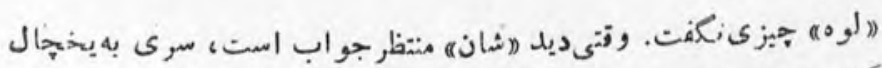

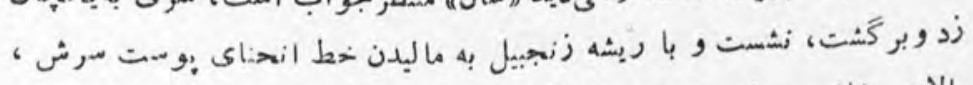

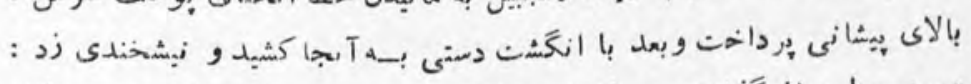

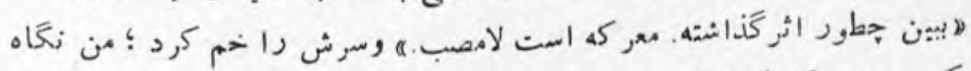

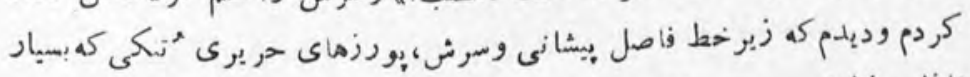

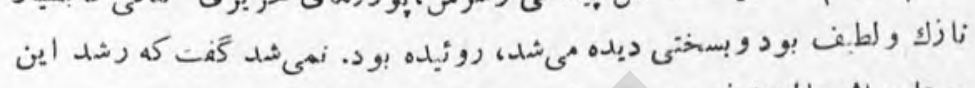

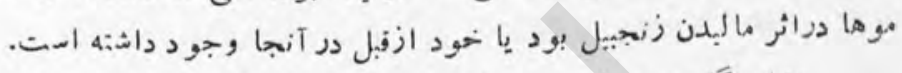

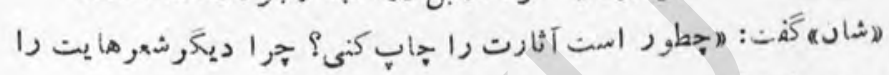

$$
\text { iهى }
$$

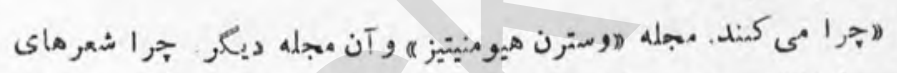

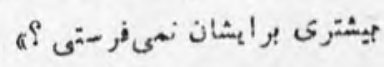

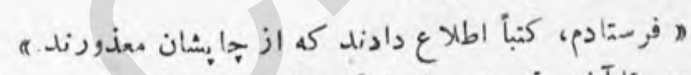

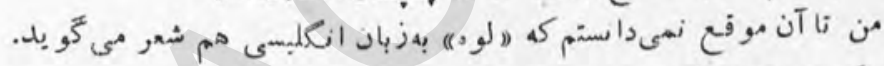

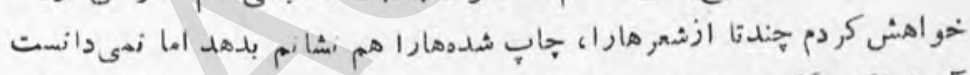

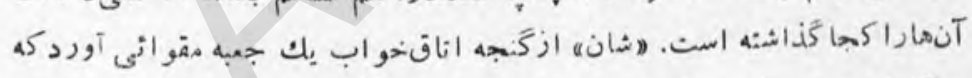

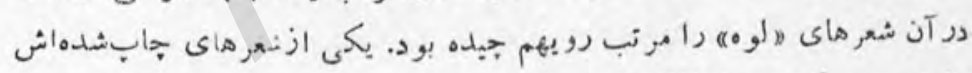

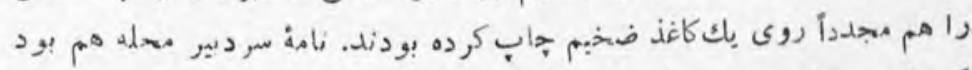

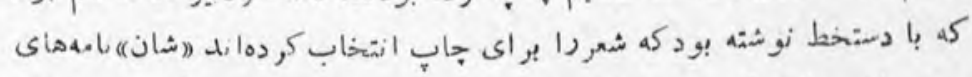

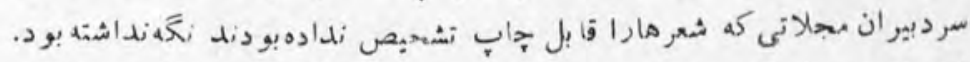

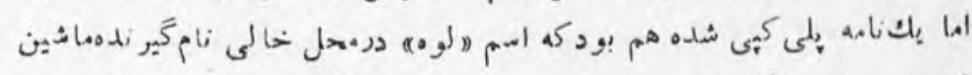

$$
\text { ثلده بود. iاهه ازاين قراربو }
$$

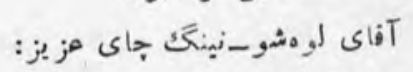

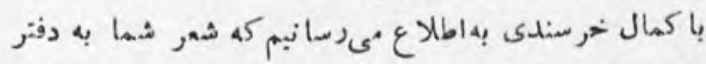

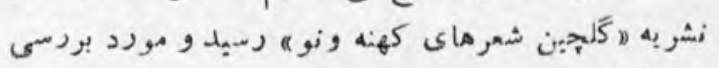

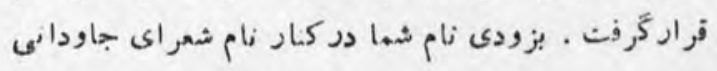




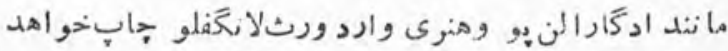

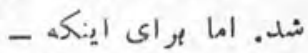

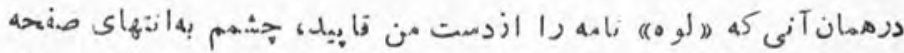

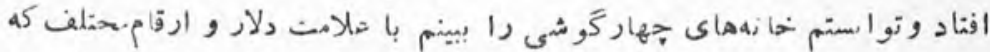

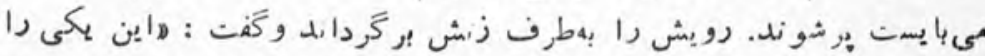

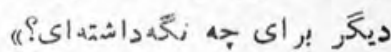

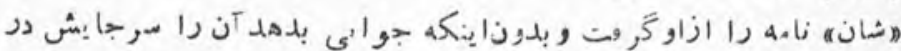

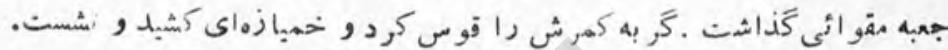

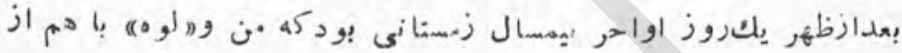

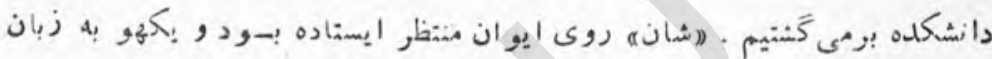

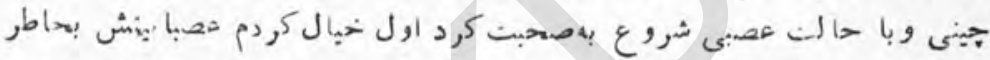

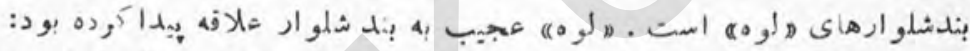

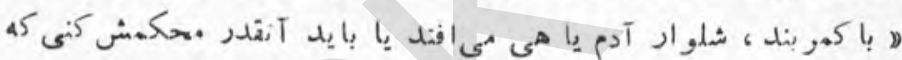

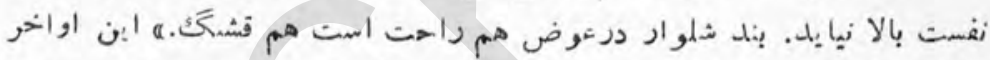

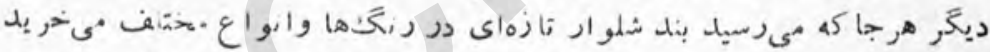

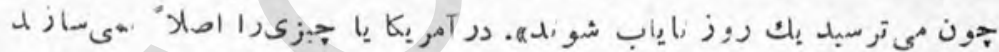

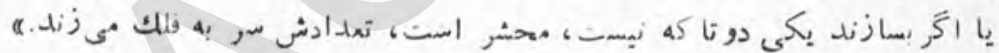

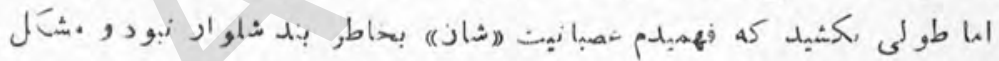

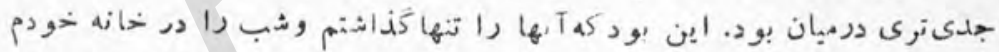

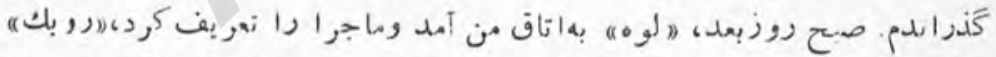

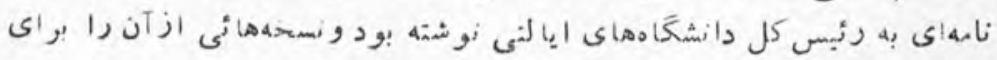

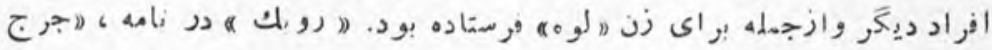

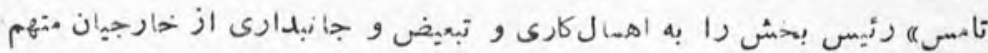

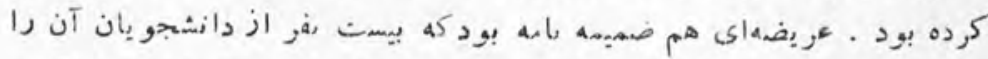

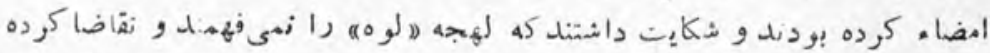

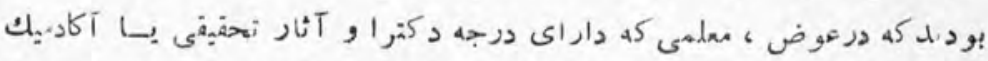

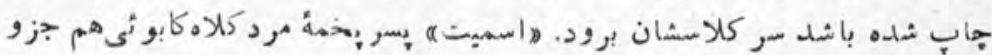

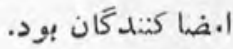




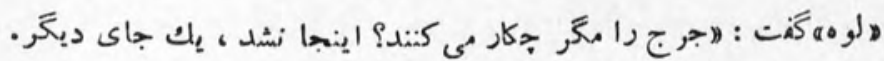

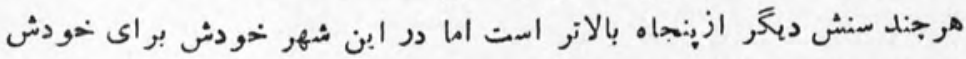

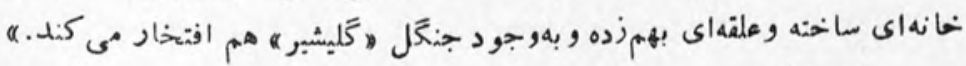

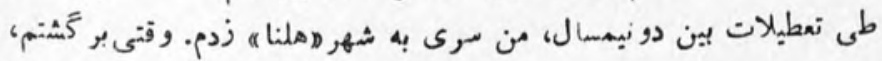

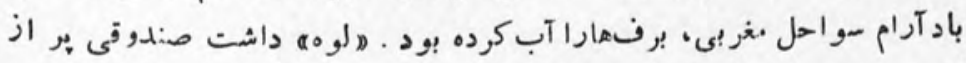

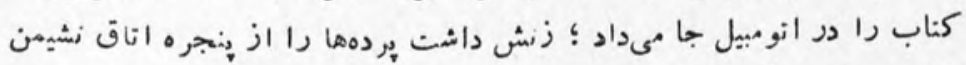

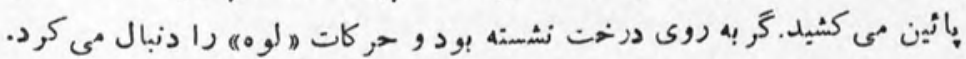

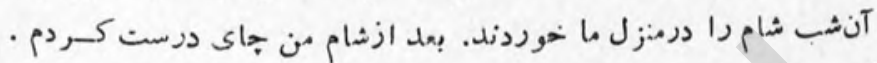

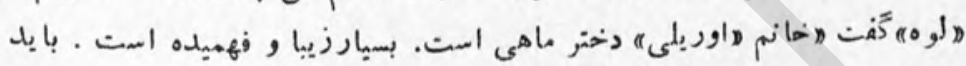

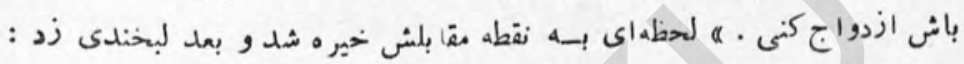

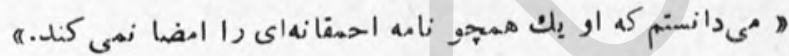

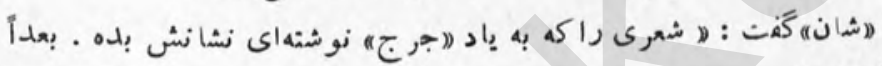
ه.

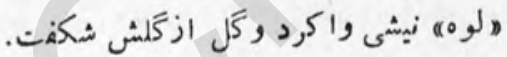

ترجه4 : صفدر تنقىزاده 
غروب يك روز زمستان ، در هوائى هـAT لود و اندوهبار ،كنار درياى

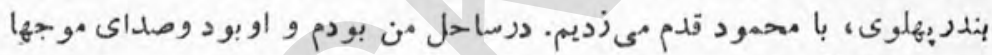
بود با هرندكانى كه دورتر، نزديك آب دريا بال هىزدند و بسوئى ميىرفتند.

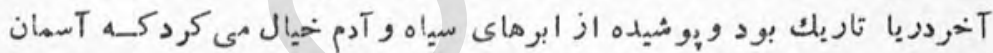

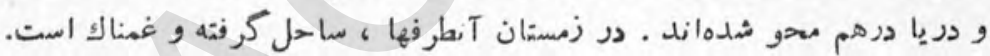

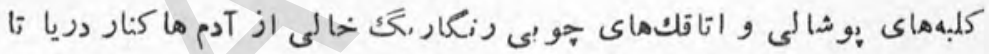

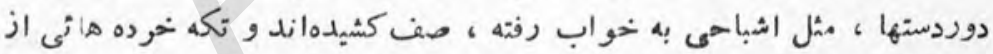

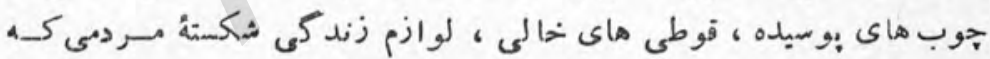

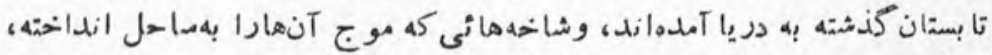
با كوش هاهى ها و صدف ها روى ماسه ها يراكندهاند . Tدم درآنجا احساس

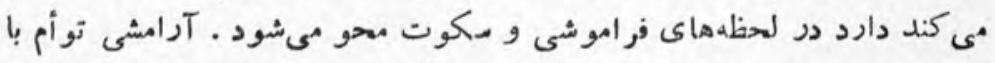

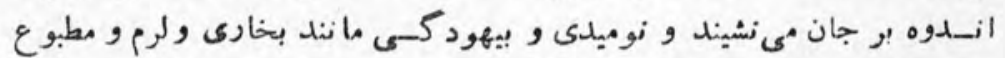

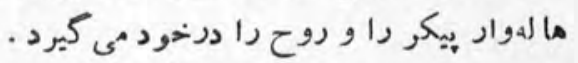

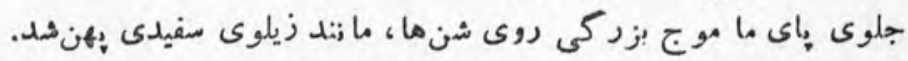

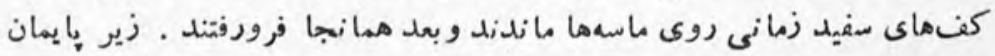

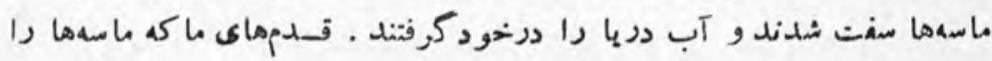


سحن - دور rq.

"ى فشردكمى Tب از آنها بيرون مى كشيد. بر كثتيم، بهعتب نعاه كرديم. موجها

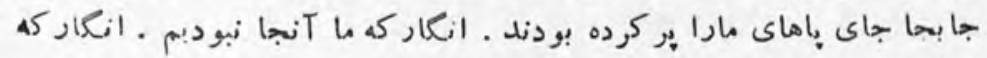

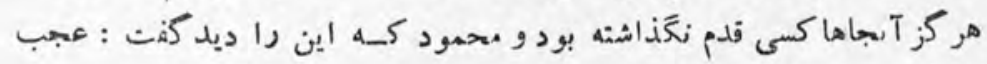

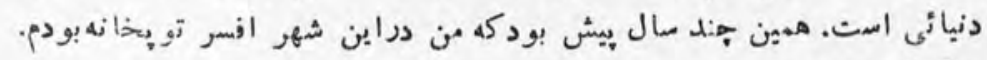

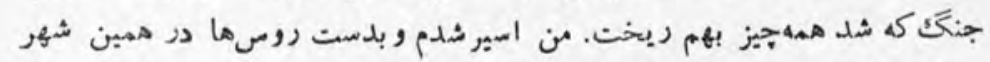

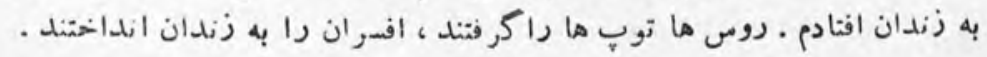

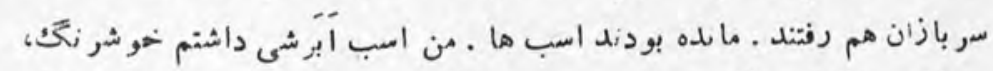

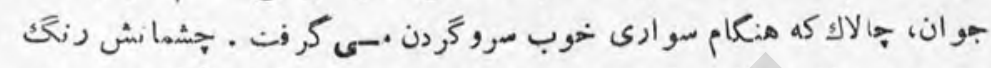

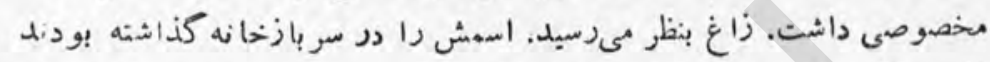

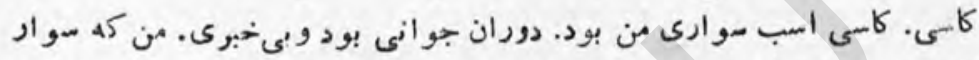

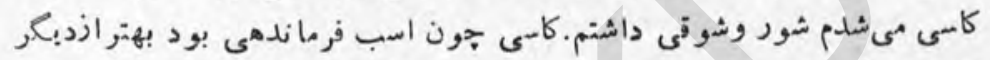

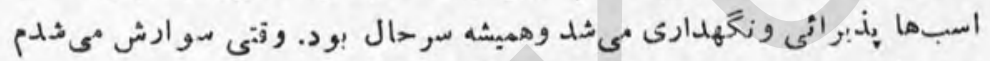

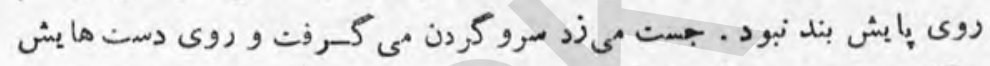

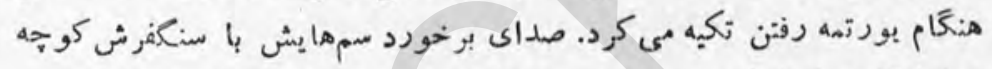

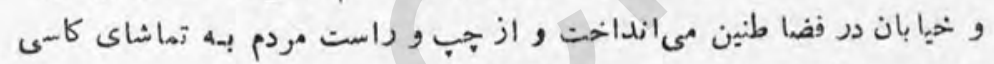
هى ايستادند كه مستازه ثىدفت و من كـه با غرور بر آن زشسته بودم سر را بالا

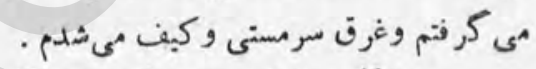

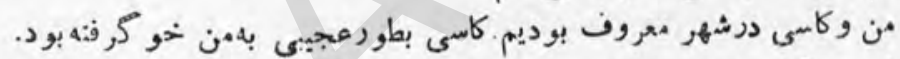

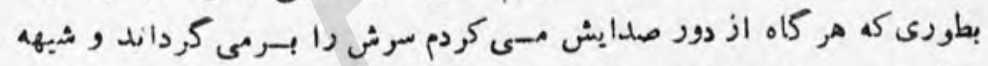

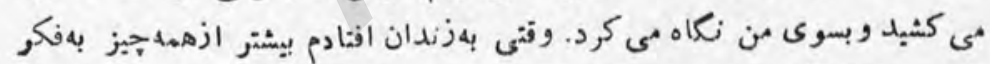

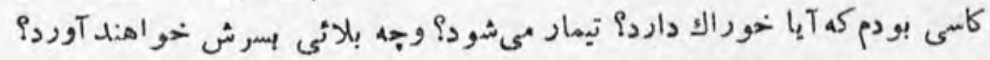

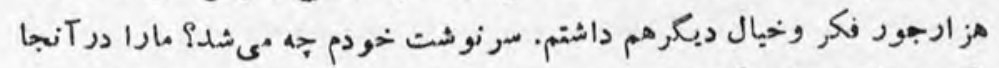

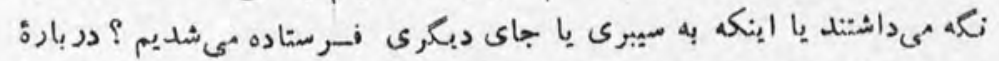

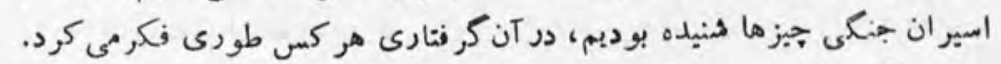

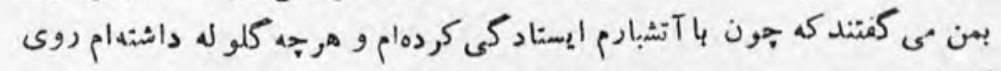

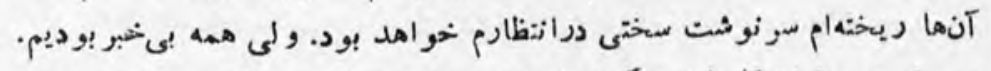

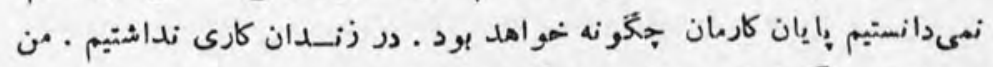

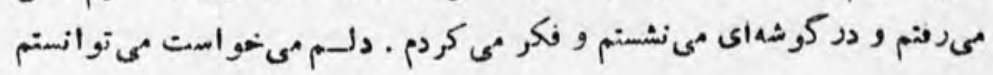




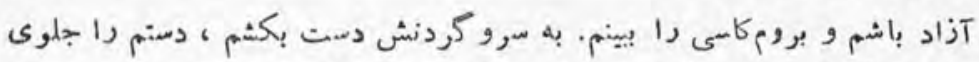

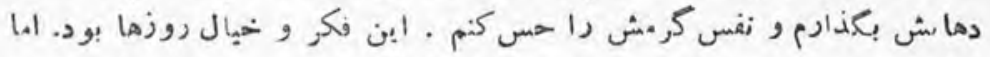

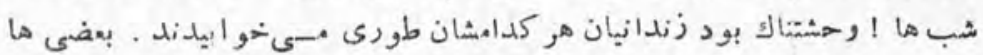

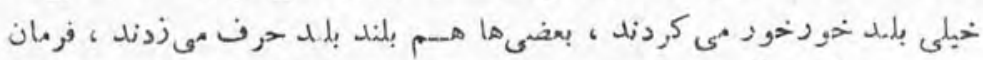

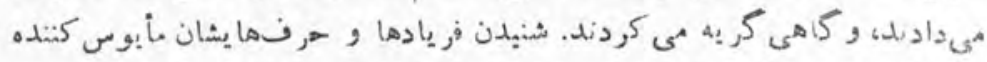

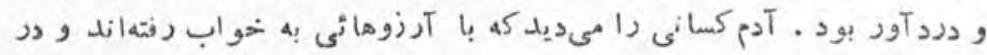

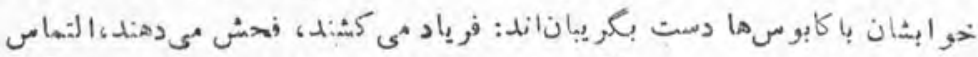

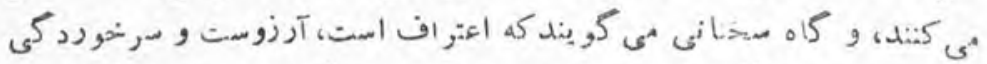

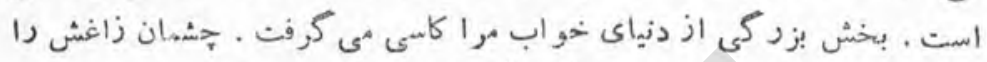

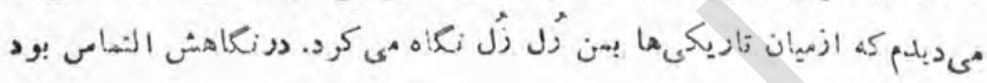

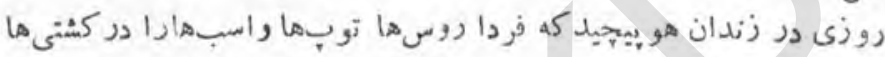
ور سرزنش

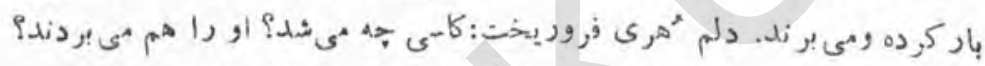

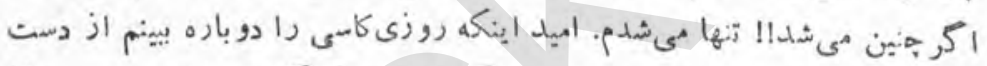

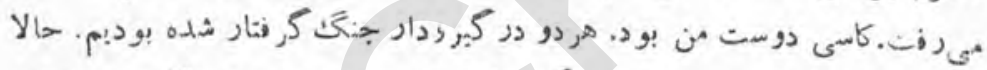

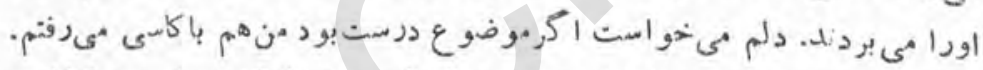

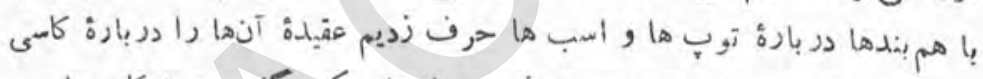

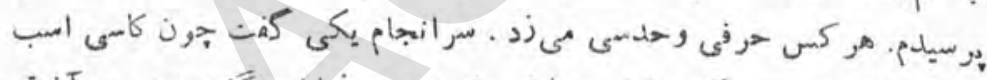

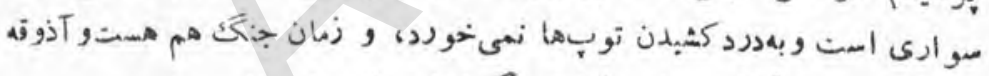

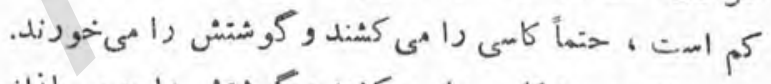

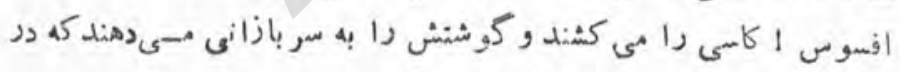

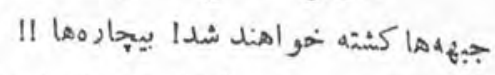

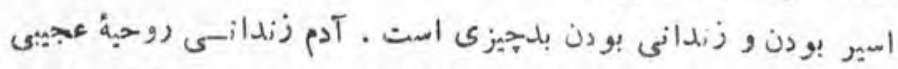

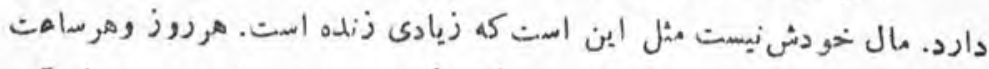

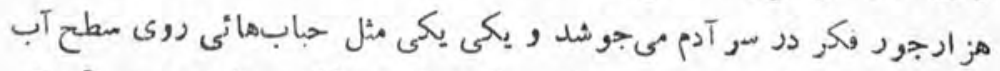

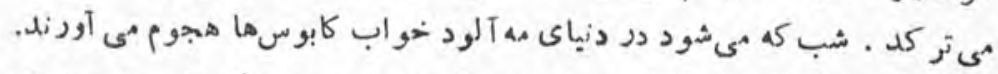

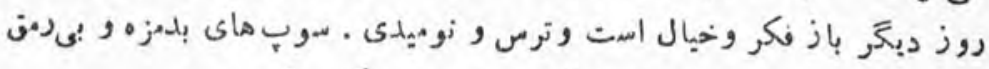

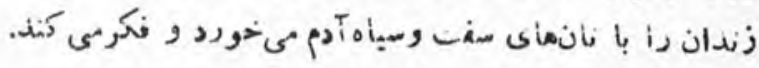




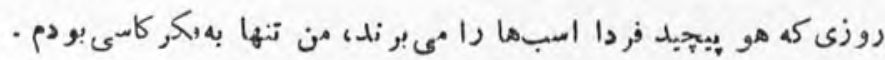

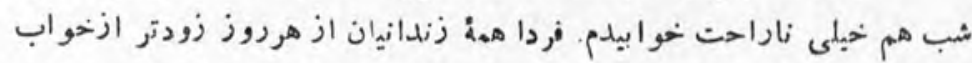

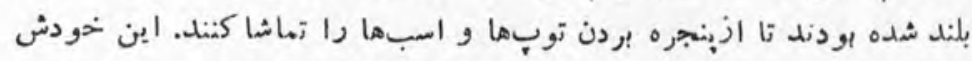

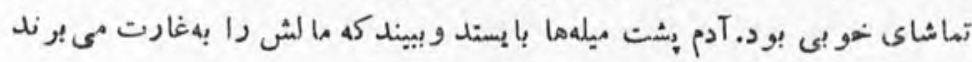

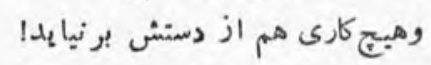

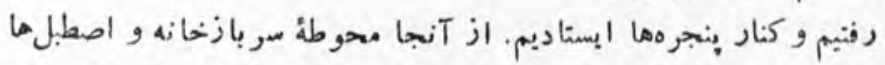

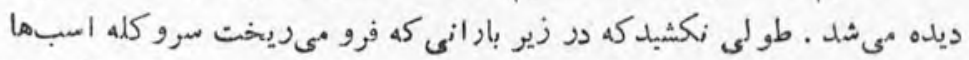

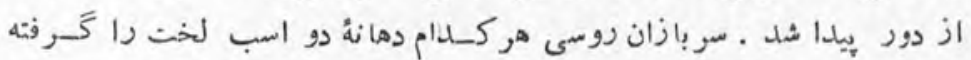

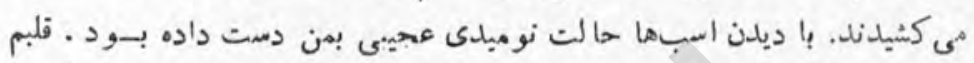

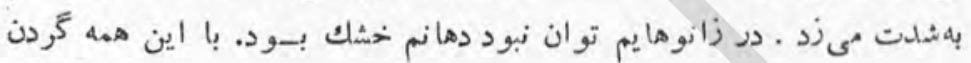

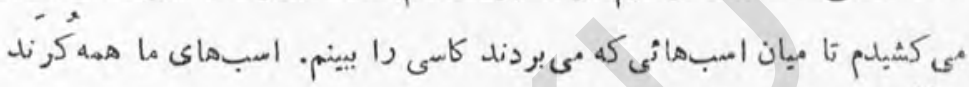

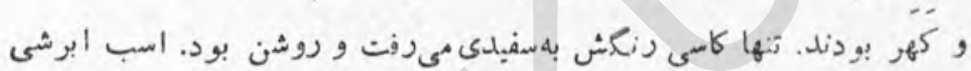

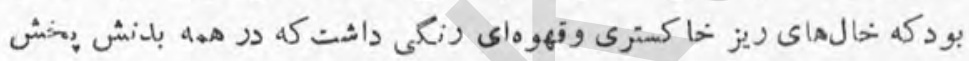

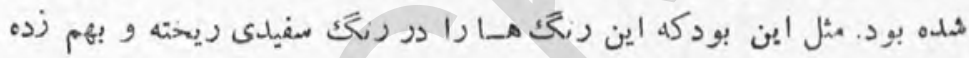

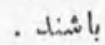
از دور رنكَك ابرش را ديدم. زفسم بهسختى بيرون مى آمد . خودش بود.

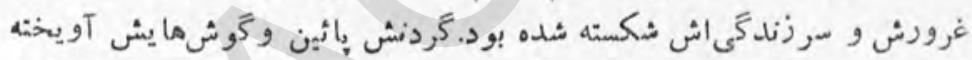

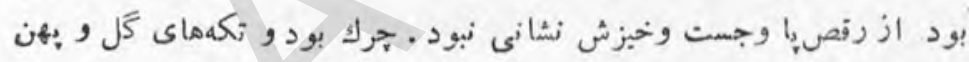

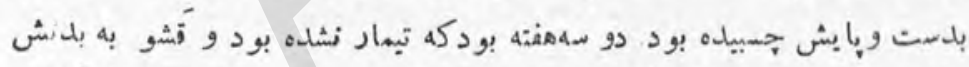

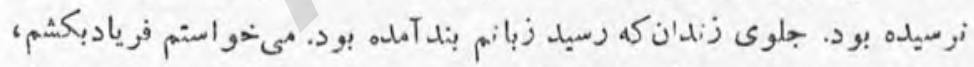

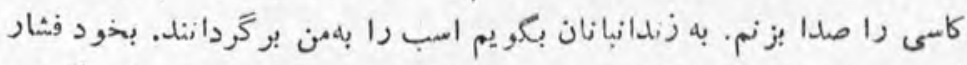

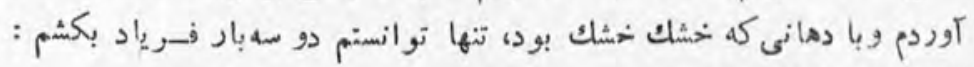

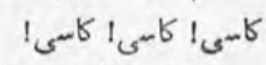

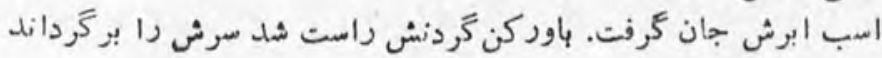

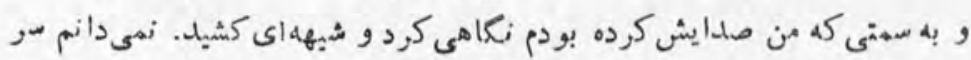

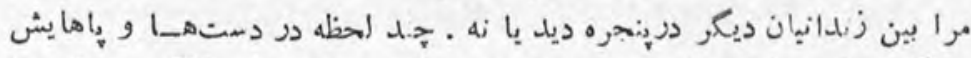

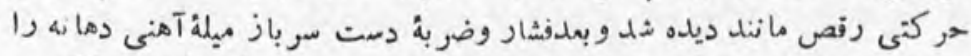

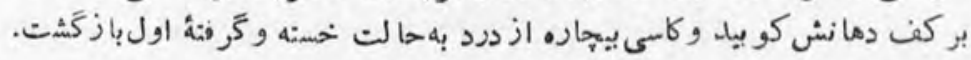




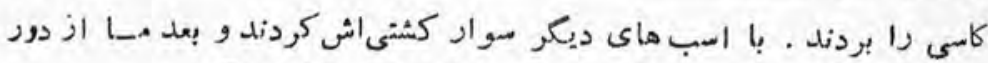

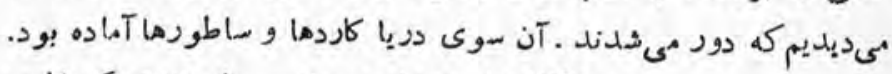

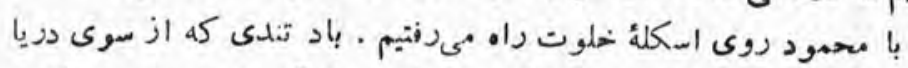

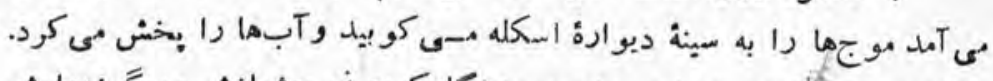

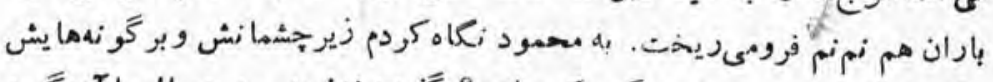

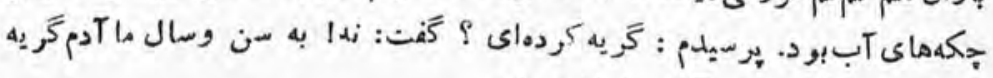

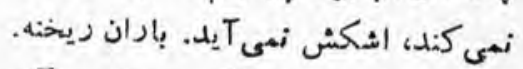

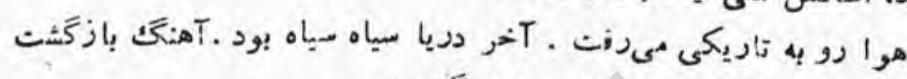

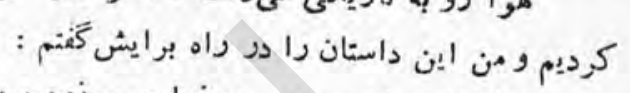

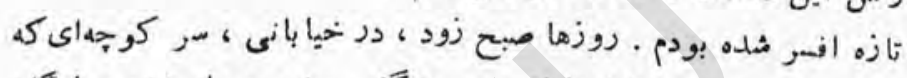

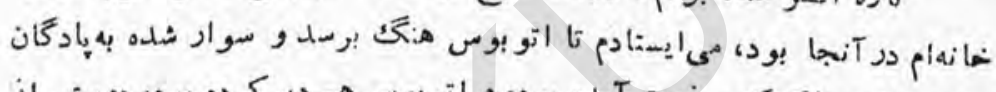

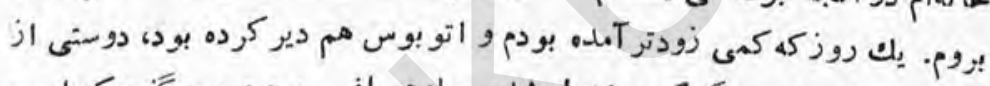

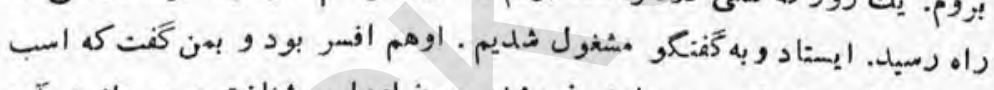

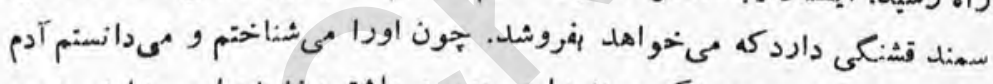

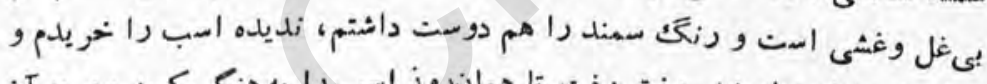

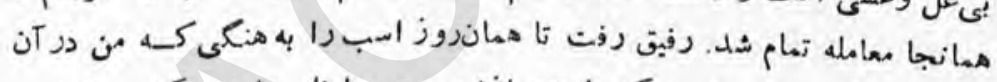

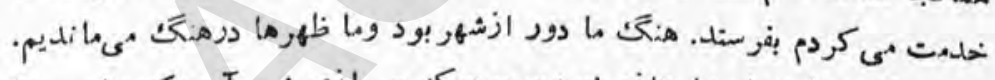

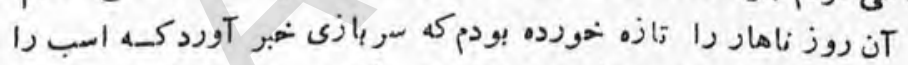

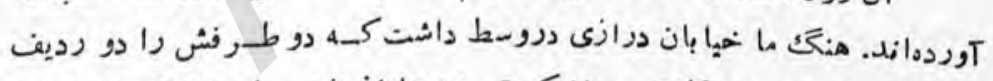

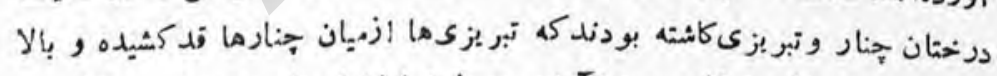

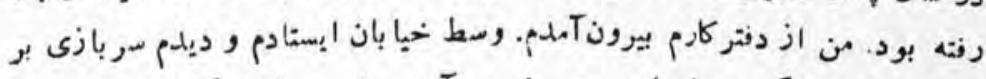

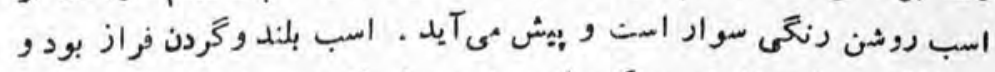

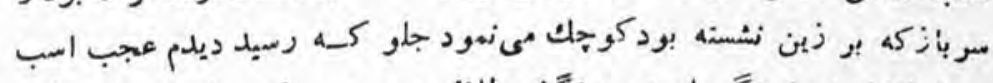

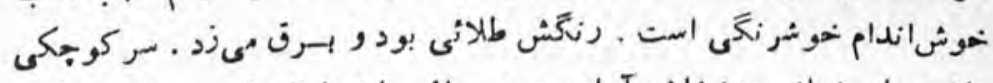

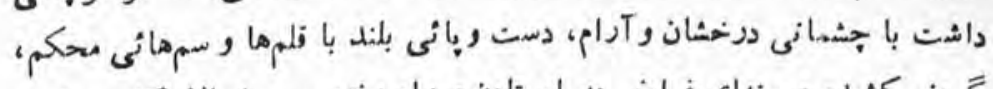

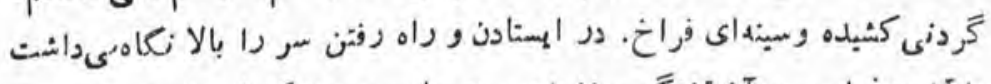

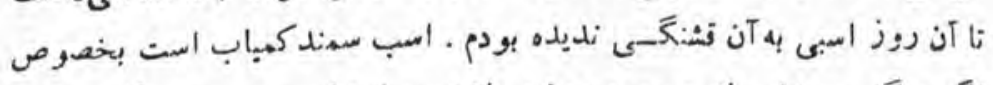

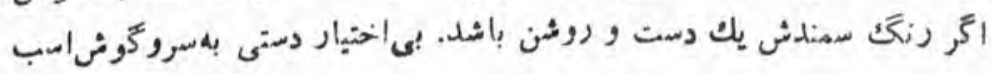




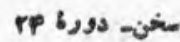
rap

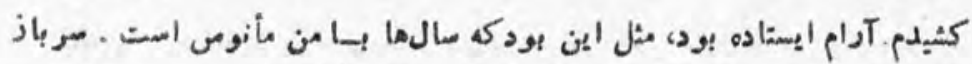

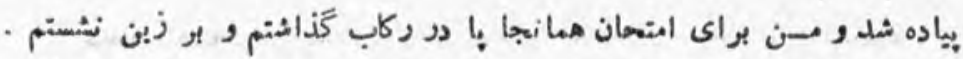

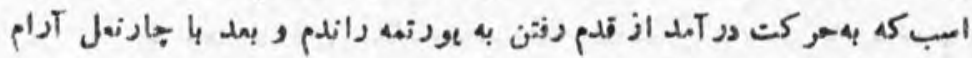

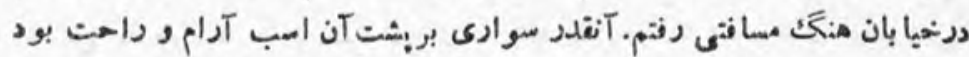

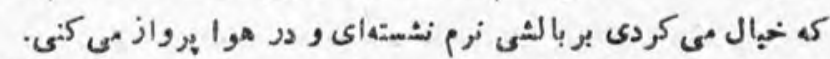

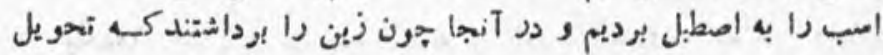

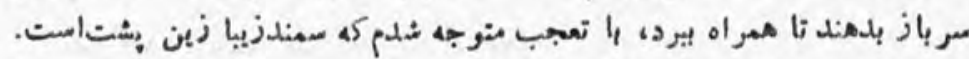

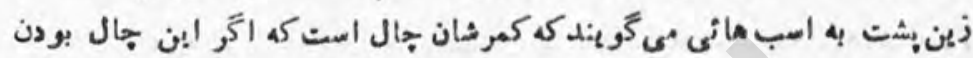

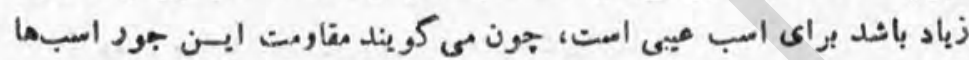

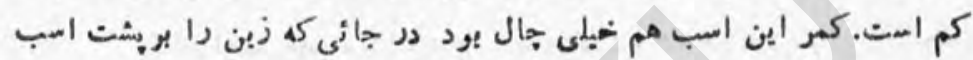

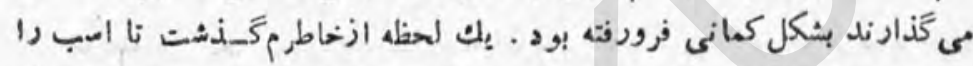

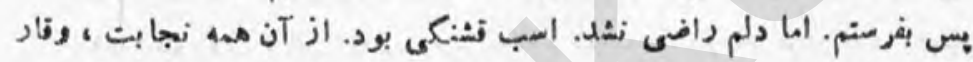

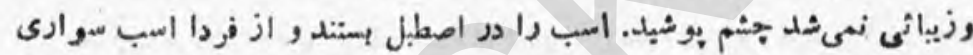

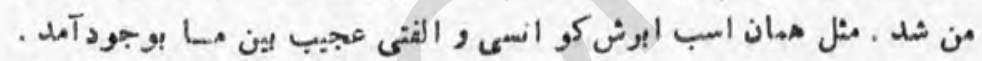

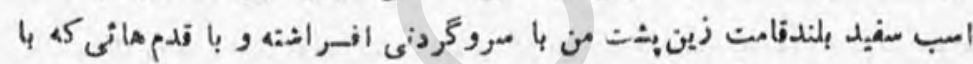

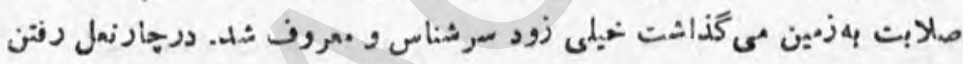

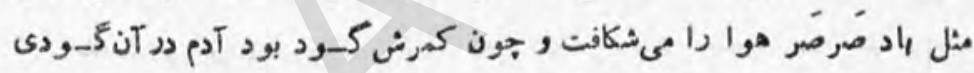

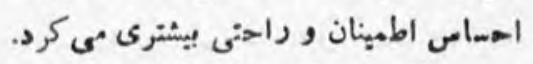

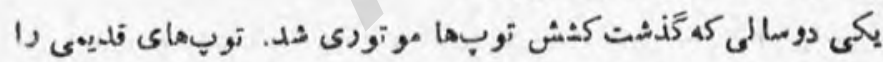

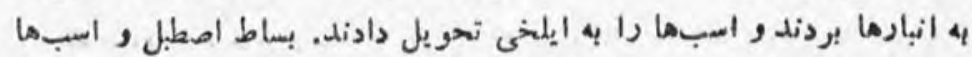

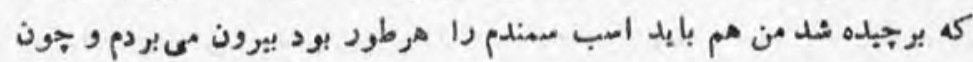

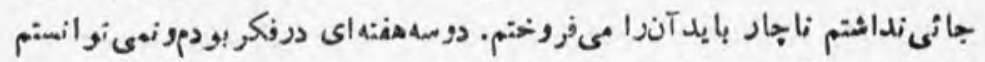

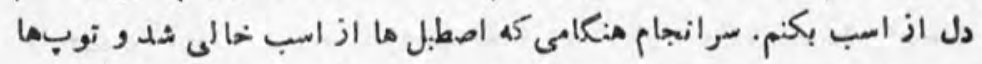

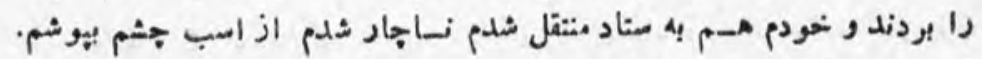

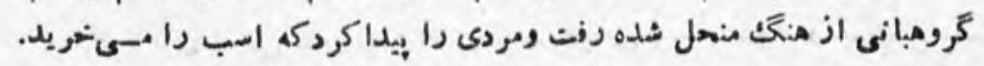

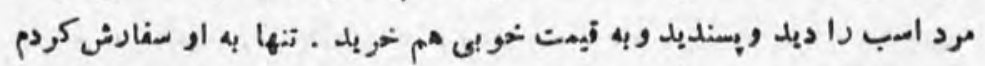

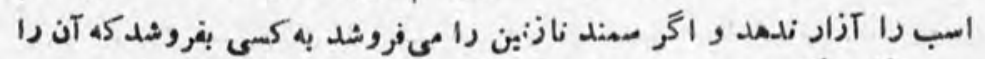

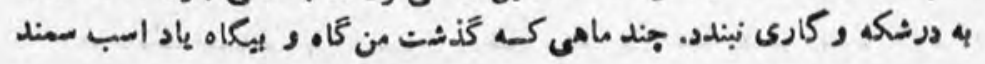


ras باران و اثك

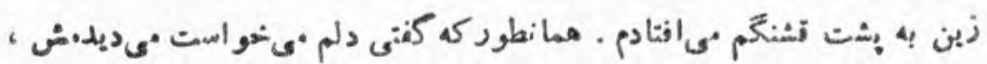

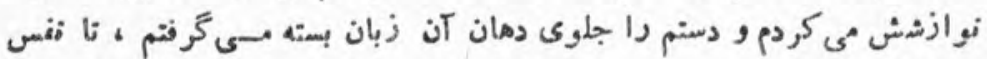

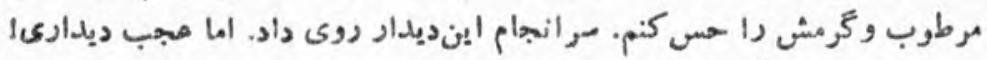

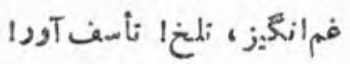

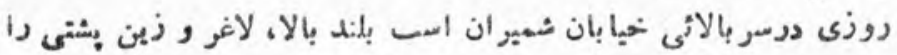

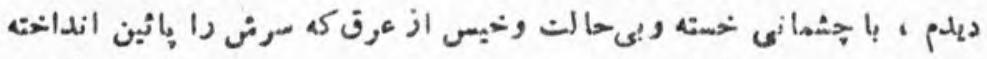

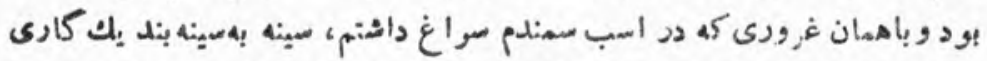

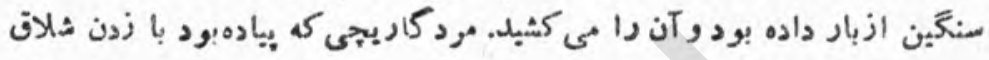

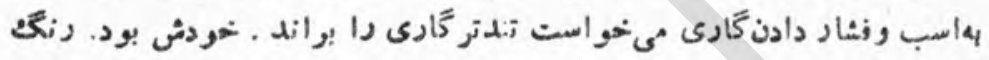

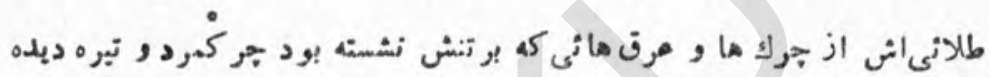

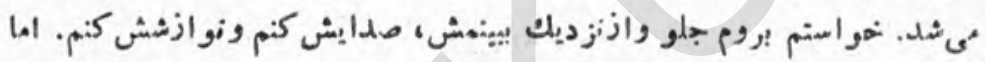

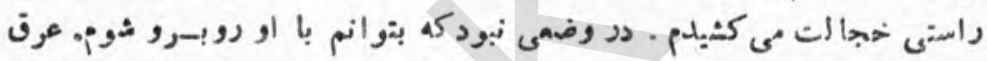

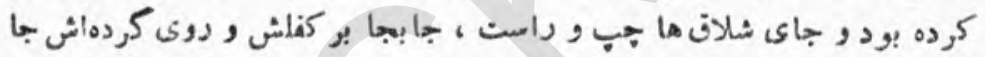

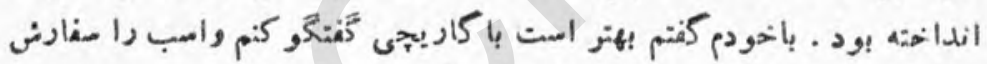

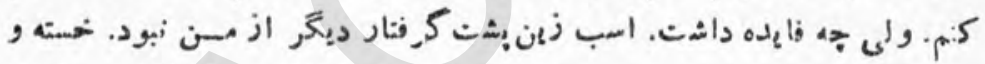

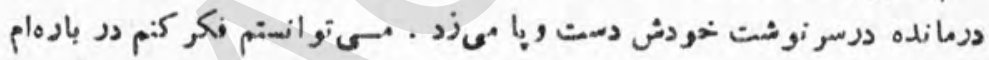

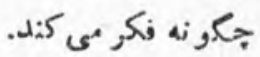

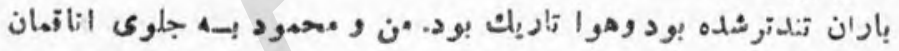

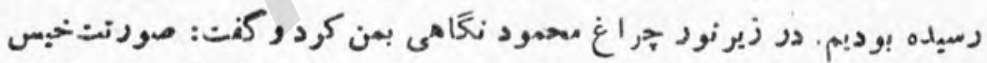

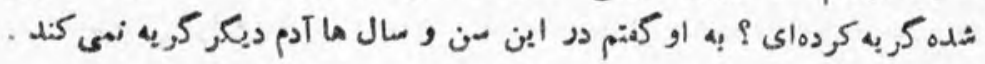
إران ديخته or ist?

بابامقدم 


\section{استاد معلم}

$$
\text { دراين بيت ازكلستان سمدى : }
$$

غر مشك بازند كور دكان در بازار

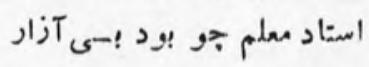

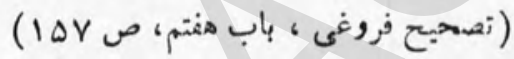

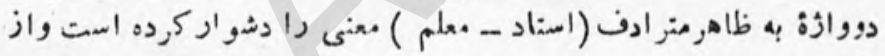

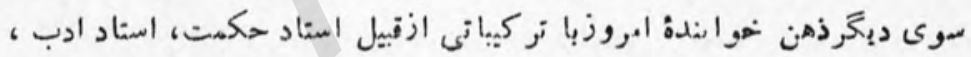

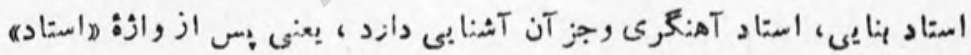

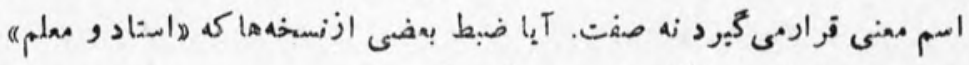

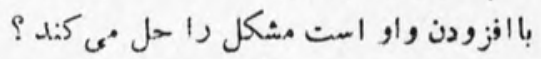

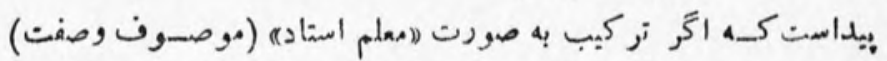

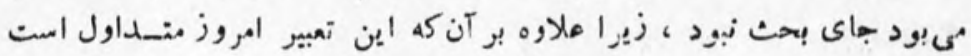

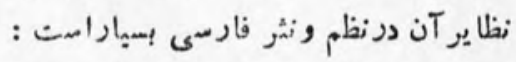

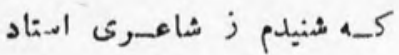

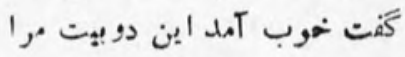

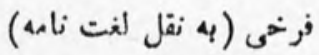

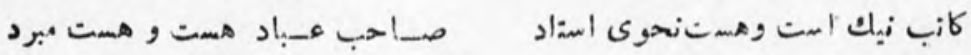

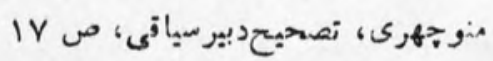


rar استاد

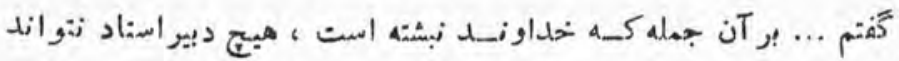

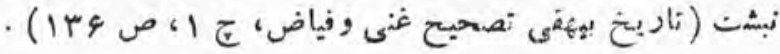

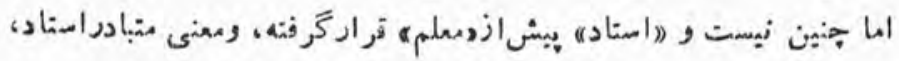

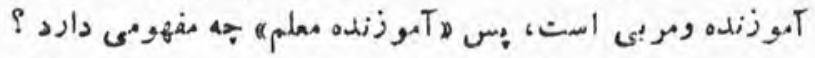

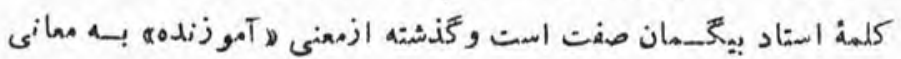
هاهر، حاذق ، بسباردازا، سرور، رئيس، بيشوا ورهنها نيز آمده واكر دربعضى

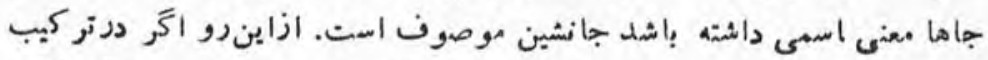

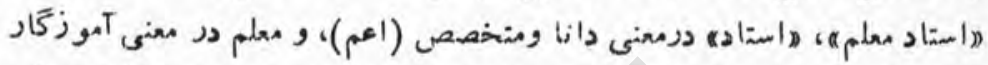
(اخص) باثد مفهوم جنمن خو اهل بود: استادى كه هملم است يتنى كارث تمليم

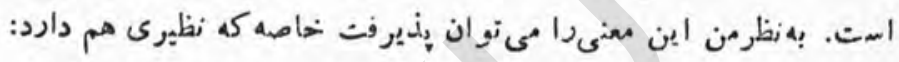
درجواهع الحكلايات عو فى Tهده است: ه ا ايشان (عرب) هون آن تختهها

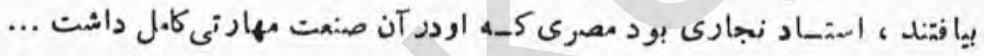

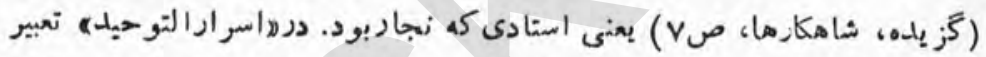

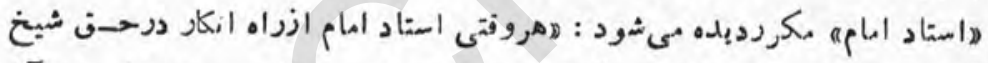

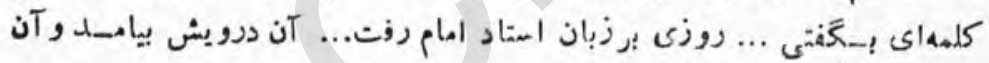

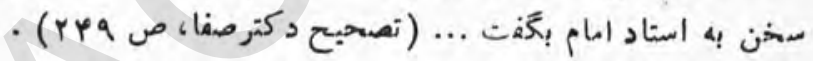

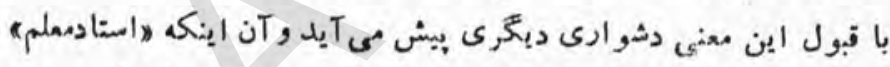

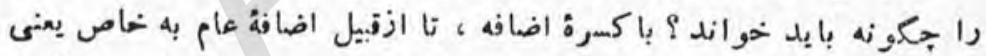

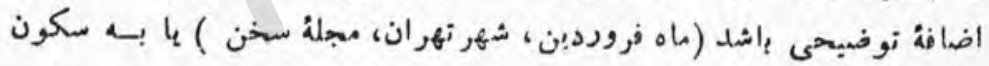

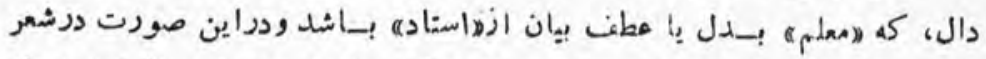

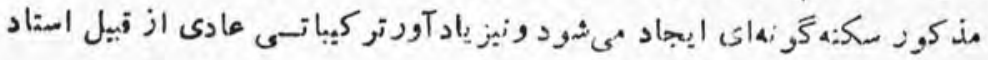
على واستادكاظم وجز آن خو اهد بود .

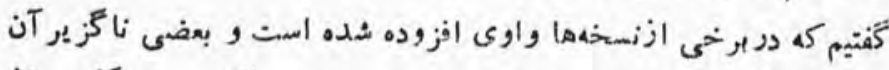

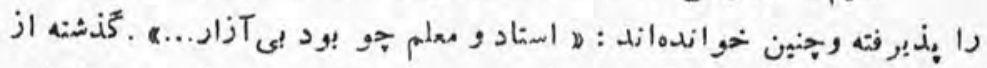

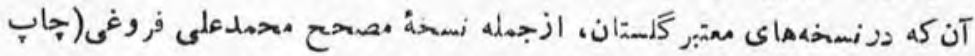

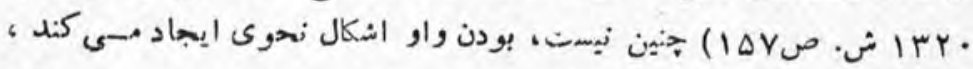

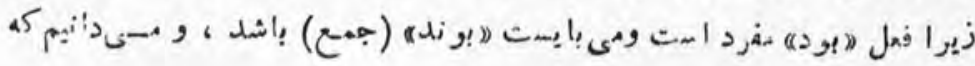


ن̈p YA

اگرفاعل جمع وانسان باند، فمل بايد به ميغة جهع بيا يد وخلاف ابن قاعده

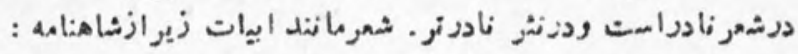

بدان دشت نهخجير 5ه بر كذشت

سواران تركان تخى هiفت هشت

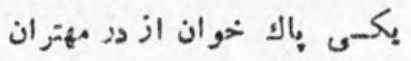

خورنها بياراست خوان اليكران

فروماند بر جاى ، نماه وسياه

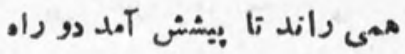

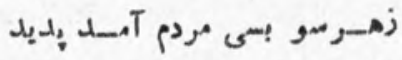

فر iكايس و كيخسرو, Tنها رسيد

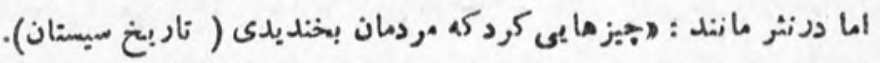

آدم وحوا بهرد ونوح وابراهيم خحليل بهرد (تذكرة الاولياء) .

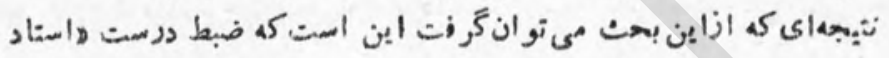

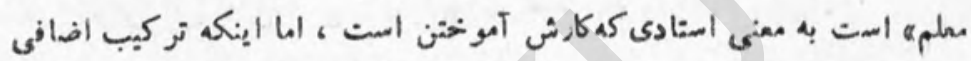

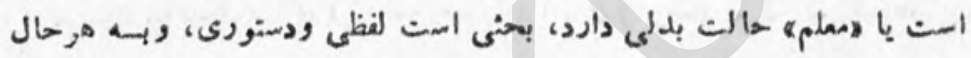

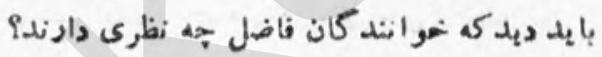

جعفو شعاد 


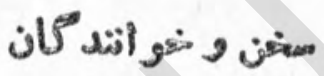

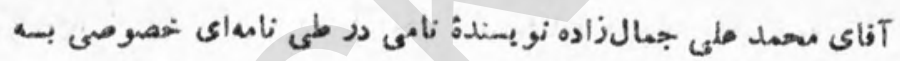

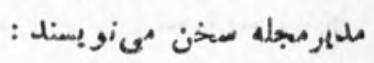

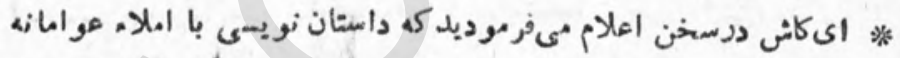

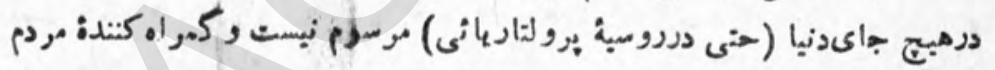

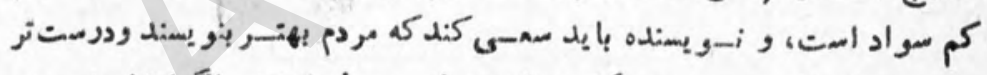

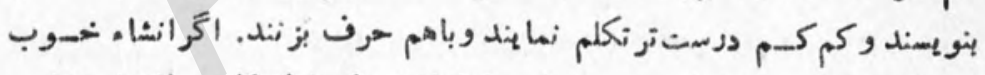

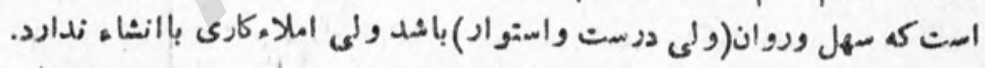

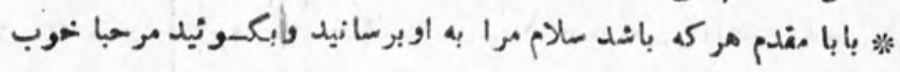




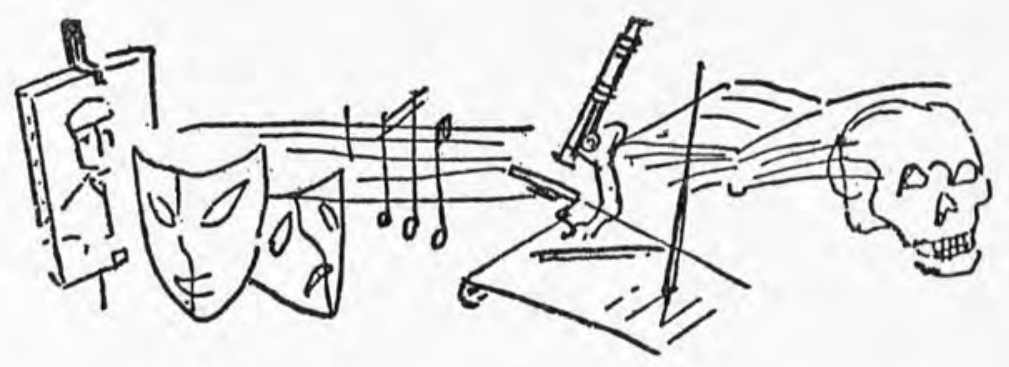

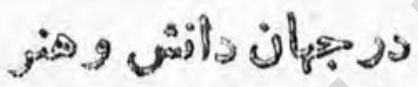

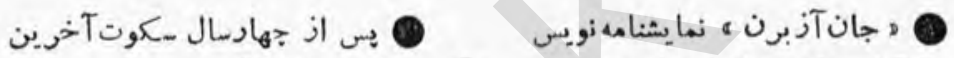

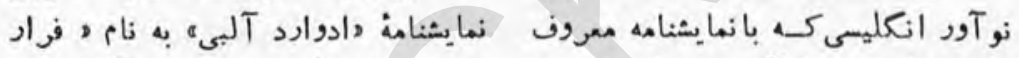

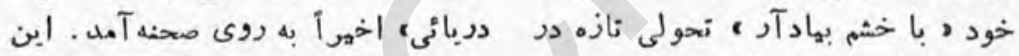

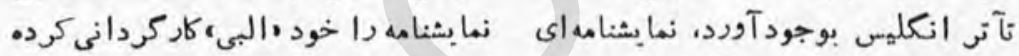

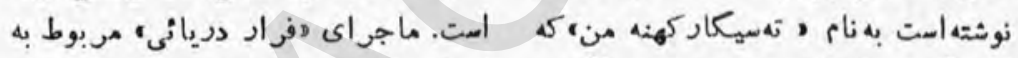

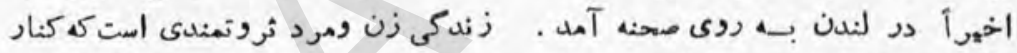

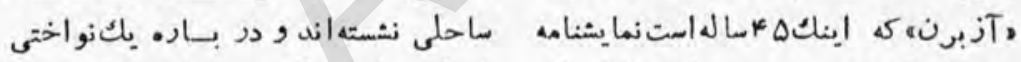

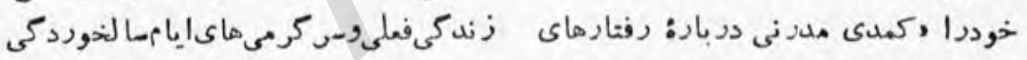

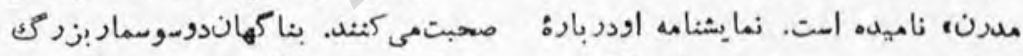

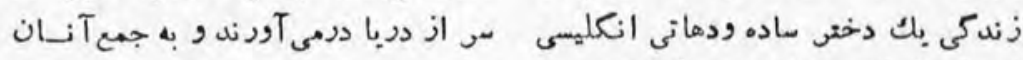

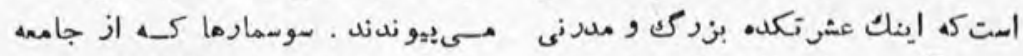

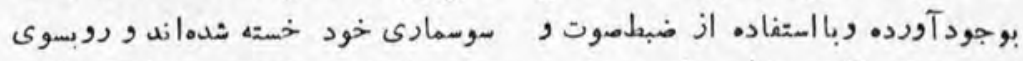

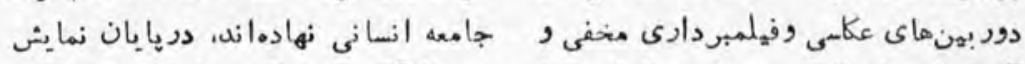

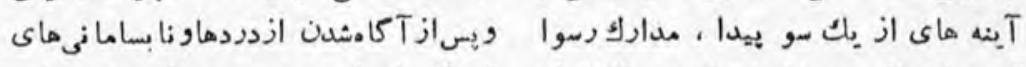

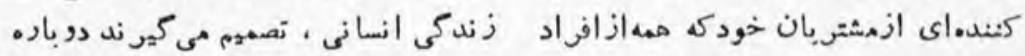

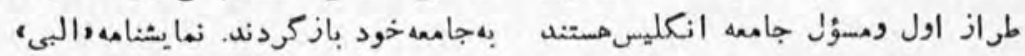

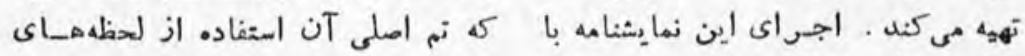

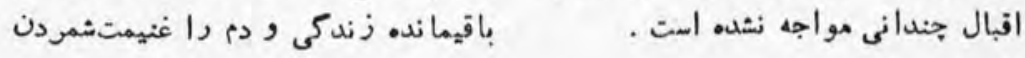


در دنياى امروز را نشان بدهل . بر ادر كوجكتر او هآلدوس هاكسلىه كه خود نويسنده بزدكى بود حدود r r ا ساليثش

اخير آ كثاب تهازهاى دربـار:

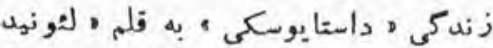

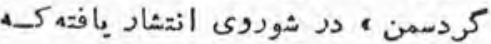

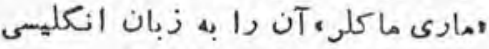

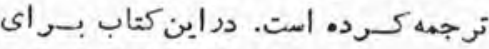

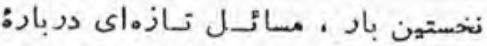

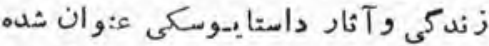

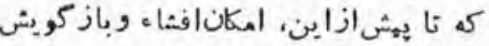

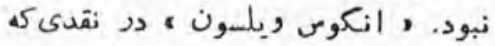
دربار: اين كتاب نوشته است آن آندا نمو نهاى

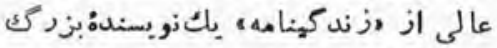
بشمار آورد. است.

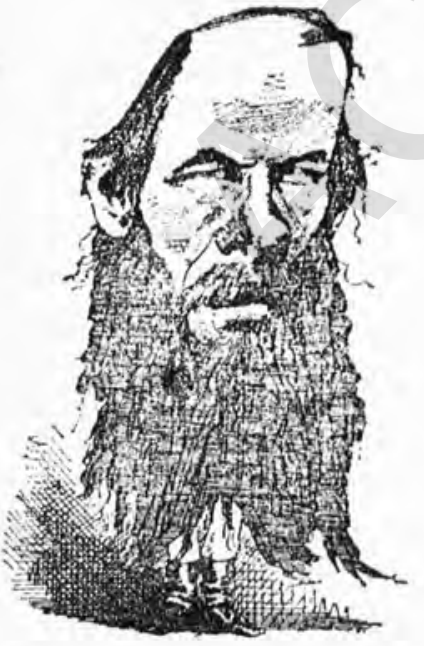

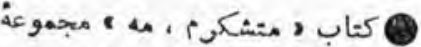

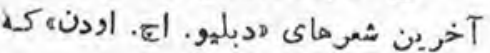

است، داراى كفت و شنود هـاى قوى و طنز آميز است و بار ديكى قدرت دالبىه

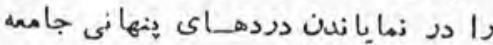

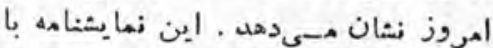

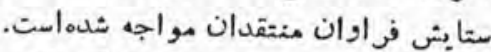
, فليكس مارياسى، كاركردان و

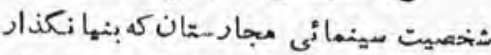

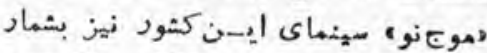

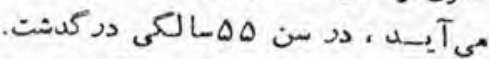

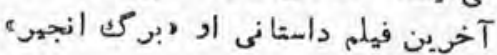
بود.

ليو اولدن، بازيكــ هنرمنل

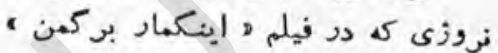

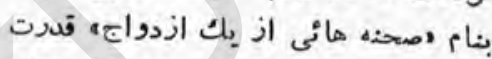

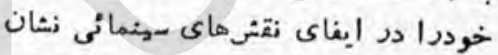

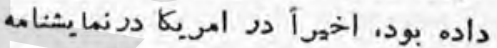

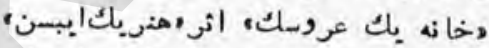

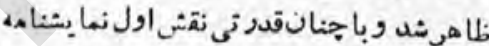

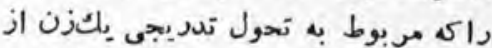

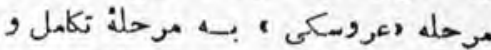

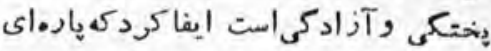
ازمنتقدان اورا بهنغوان جمر مدست ترين بازيكى زن تآتى دردنيا بشمار آوردهاند.

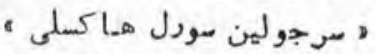

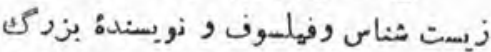

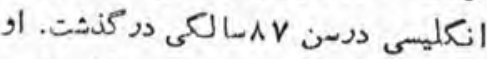

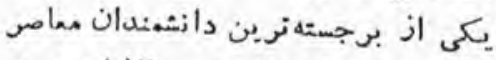

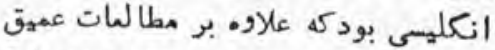
در رشته زيست ثناسى و تهقةق در بارة بارة

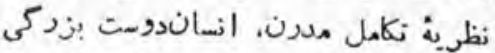

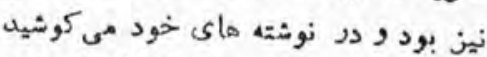

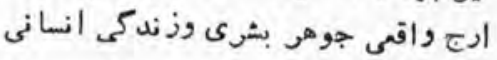




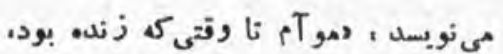

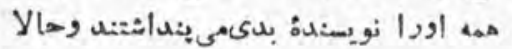

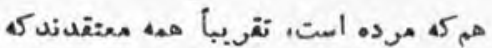

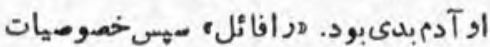

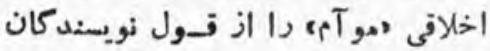

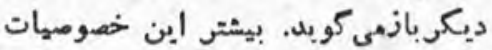

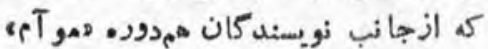

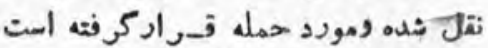

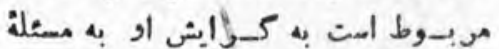

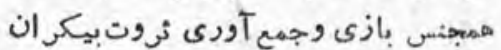

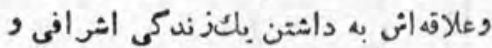

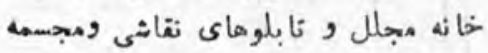

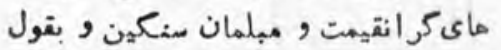

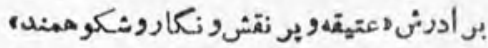

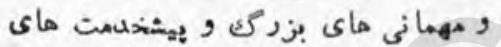

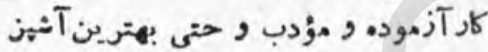

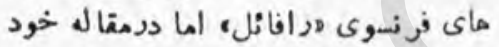

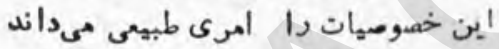

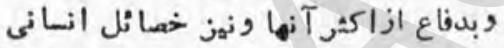

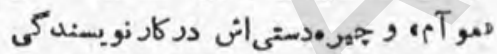

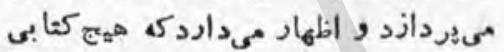

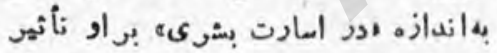

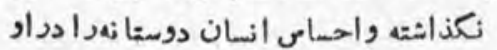

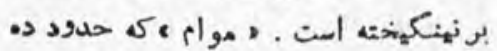

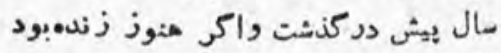

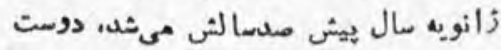

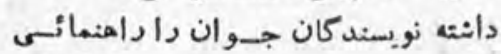

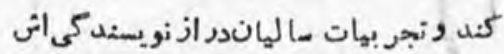

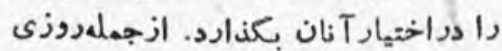

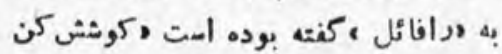

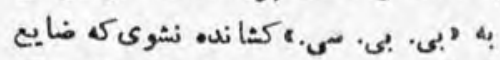

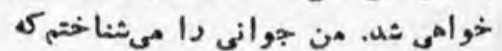

اخيرأ انتثار يافتا، بـا اقبال و تمجيد

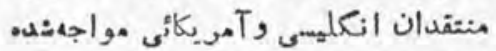

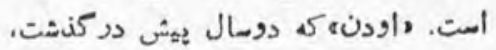

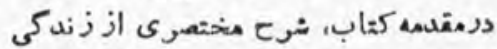

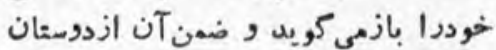

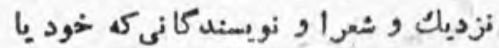

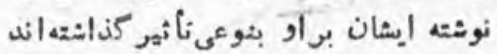

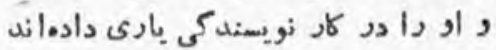

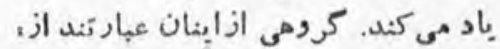

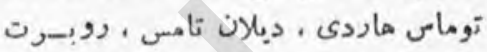

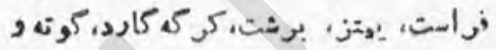
هوريس

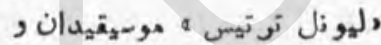

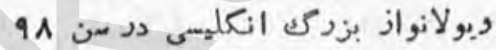

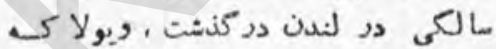

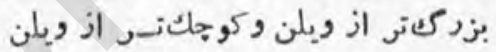

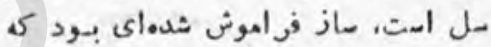

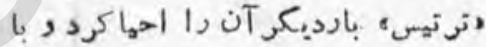

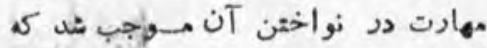

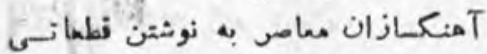

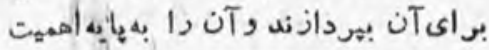

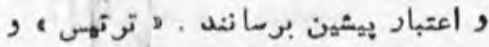

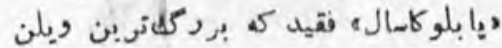

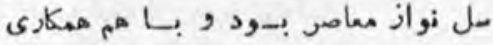
تزديك داشتيله، هردو دو 9 ب دمامبرسال

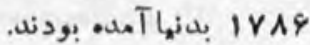

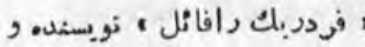

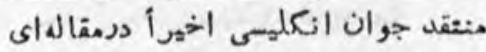

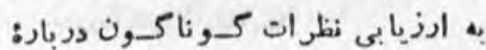

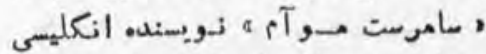

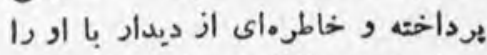

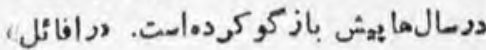


نظل : برايم مىفرستيل مى مورانم و حدود

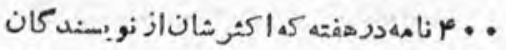

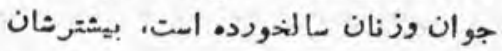
عكس هاى خود را جوف نامه مي فرستيلد

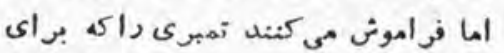

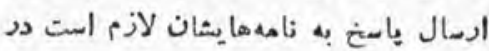

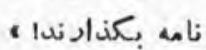

جنين اظهار نظـرى بـراى شخصص

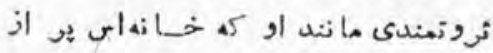

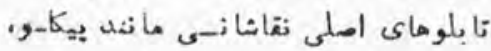

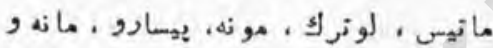

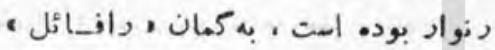

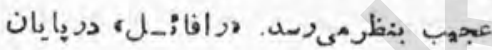

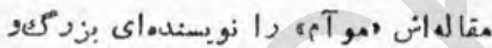

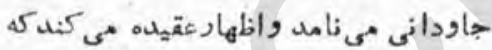

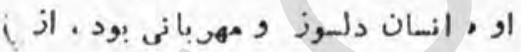

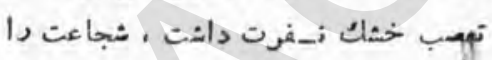

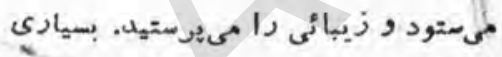

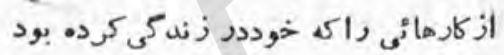

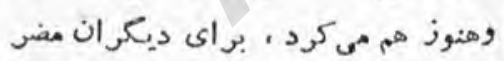

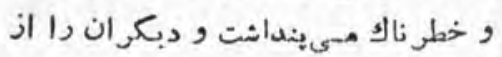

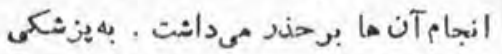

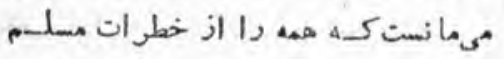

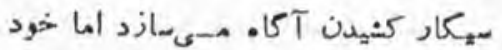
روزى صدسيكار ^ى كثد.

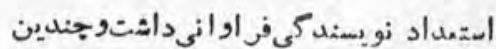

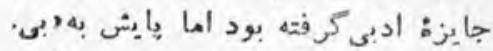

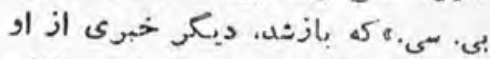

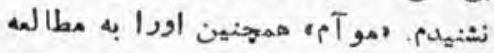
كثاب بطود مداوم ترغيبمى كندوز ندكى آني

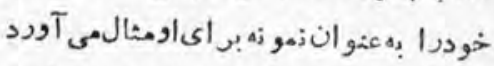

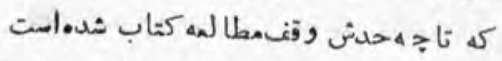
وجكو نه هiوزهم اينكاردا دنبالمى كني.

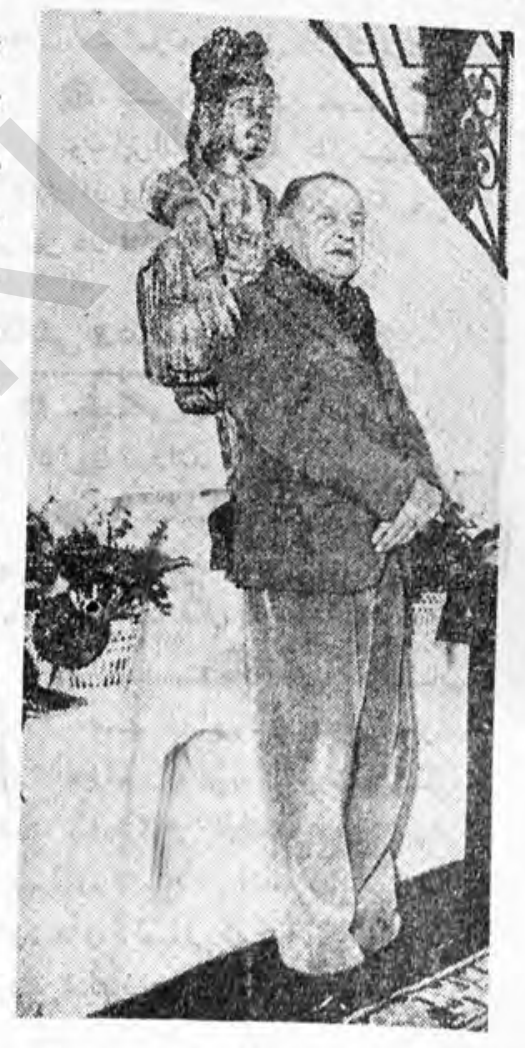

دالاوه بر كثاب، هفتهاى حدود بئج بهث نويس كتابهاى تاز.اى راكى براى باظهار 
Tور

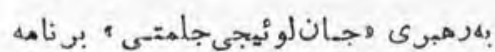

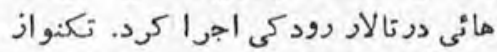

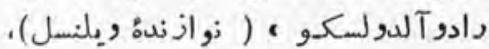

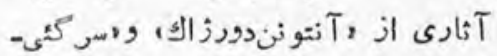
يروكوفيف،

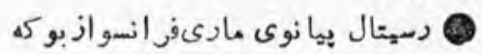
در تعأتشهر.

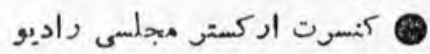
تلويزيون ملى ايقان بـهرهبرى ادرين-

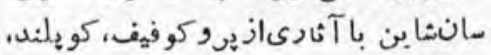
هندل، مندلسون وروسل در تعاترشهر. من

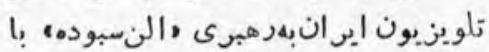

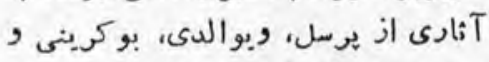
برنين در تثاتى شهر.

\section{نقاشى وعكاسى}

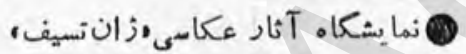

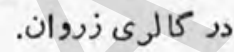

مايثكا.Tثار نقاشى هنرمندان

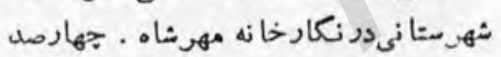

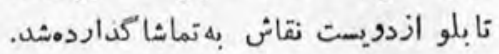

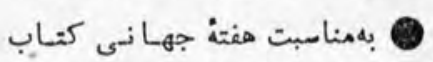

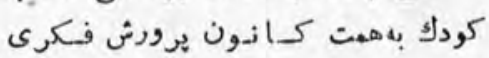

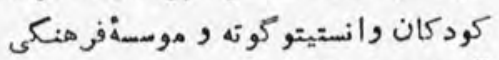

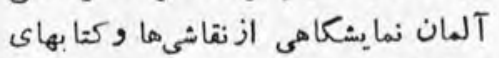

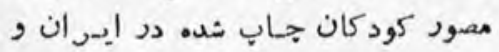

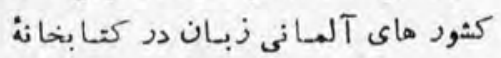

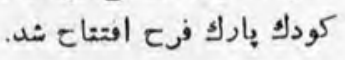

مرون كودرزى در دانشكا. كلمبيهاى امريكا.

مايشنامـه دسلام و خداحافظ،

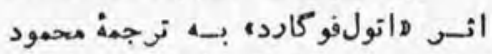

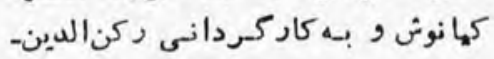

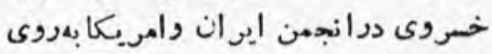

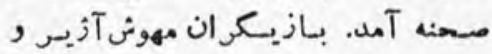
سمروس מתيف

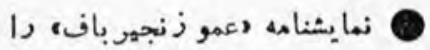
كرو. تثاتى تجربى ايران به كاركردانى زئى

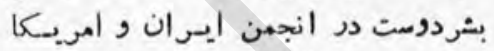
بهروى صحنه آمد.

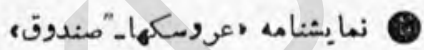

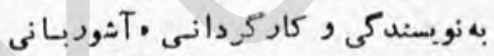

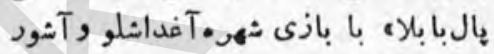

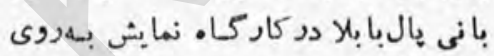
صنيه آمب.

نهايشـناهه יقهـر در عقـرب،

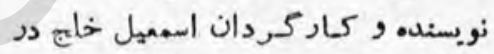
كاركا. نمايش.

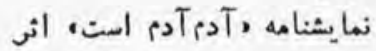

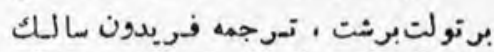

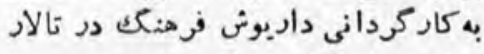
مولوى دانشكاه تهر ان.

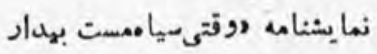

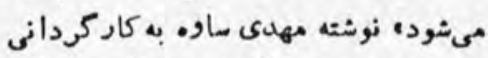

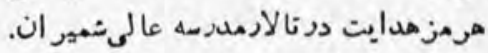

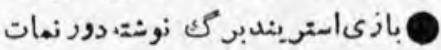

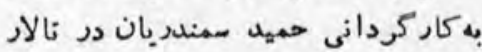

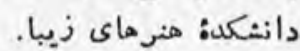
مو سميةى دنى

اركستر سنسفونسيك تهربان 


\section{$\varphi \cdot \Delta$

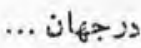

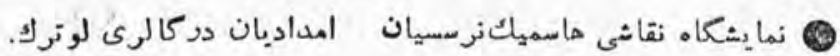

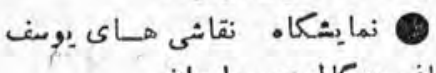

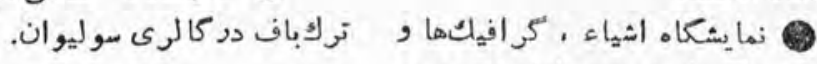

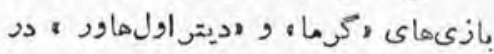

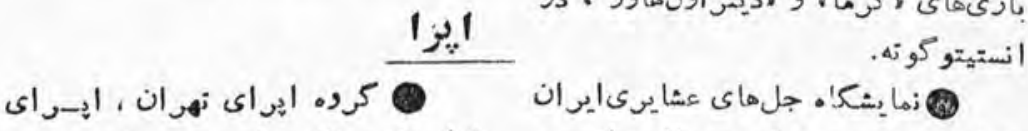

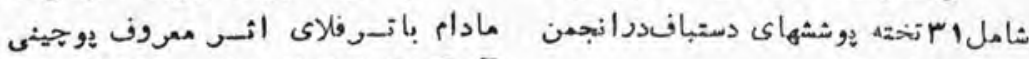

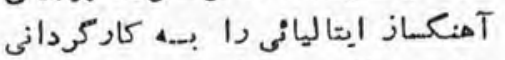
عنايت رضائى در تالار رودكـي به روى إنى

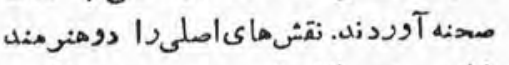

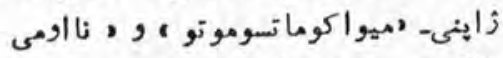

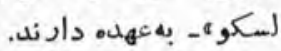
نخستهن اجراىاير ایىلوجهادى

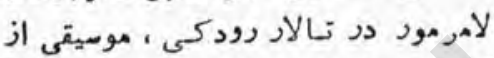

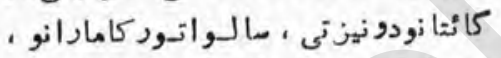
دهبر اركستر ما نريكو دتودا ، كاركردان

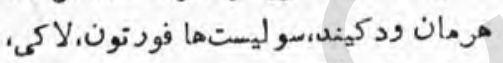

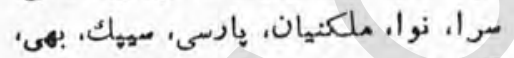

$$
\text { كوزوين. }
$$

W.

\section{آواز}

|نريكوماسهاس كنسر تى درتالار

$$
\text { رودكى به نفع امورخهيه اجر اكرد. }
$$

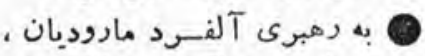
سازمانكر هلى إ.ران هآثارى ازآوازهاى مارودان

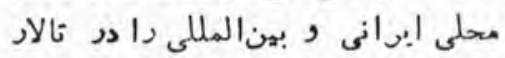

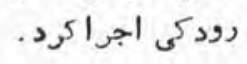

كروه بالأ اشتو تكارت بر نامهها:تى 4!

درتالاد دودكى اجراكرد. اننكروه ورق

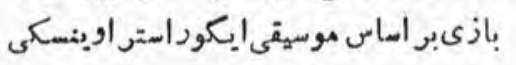

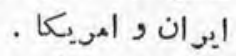

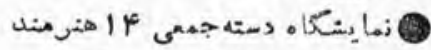

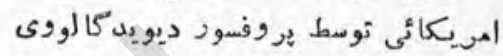

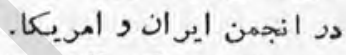

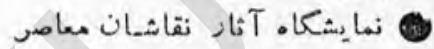
ايران در كالرى زدروان . نمان.

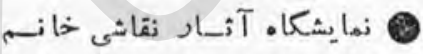

$$
\text { سمدوتى دركالرى ليتو . }
$$

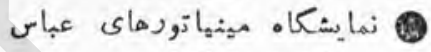
جالالى سوسن آبادى در كالرى سيحون.

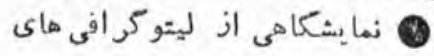
نقاشان بزرك دد كالرى ليتو.

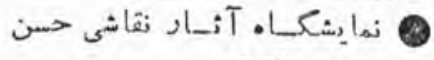

$$
\text { هر تضوى در تهر انكالرى. }
$$

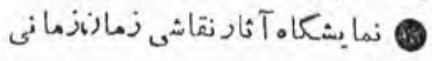

$$
\text { درتهر انكالىى. }
$$

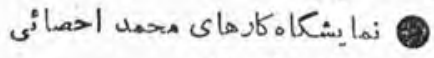

$$
\text { درانجهن ايران وامريكا. }
$$

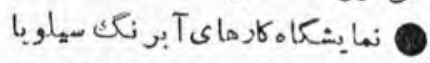

ادواردز كلستا نه در انجمنائمان ان واهريكا.

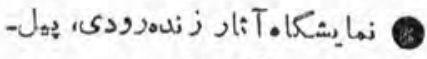
آرام وتبريزى درنكارخانه .

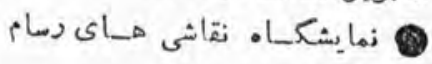
ارزنكى دركالرى سيحون. نمايشكاه نقاشى هـاى داى داود 
كودكان و نوجوازان بان بان نقاشى هاى إنهن

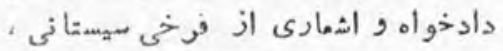

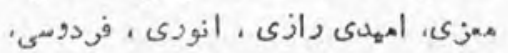

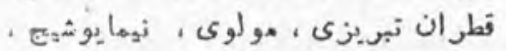

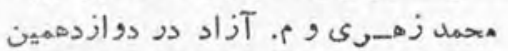

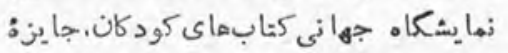

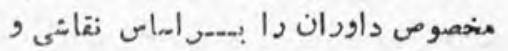
صنهده آر ائى دريافت داش داشت

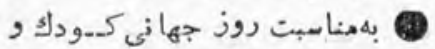

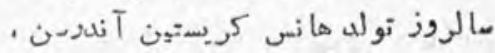

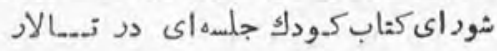

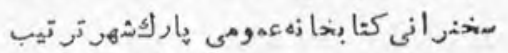

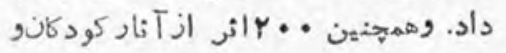

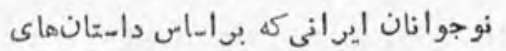

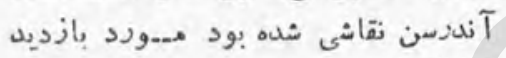

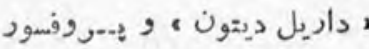
قراركرفت.

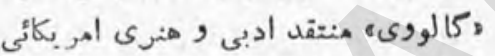

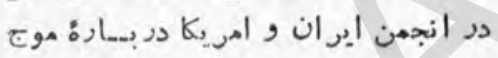

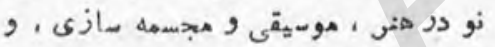

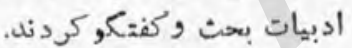

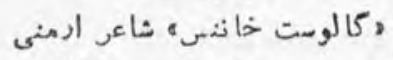

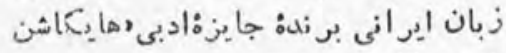

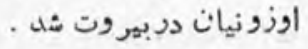

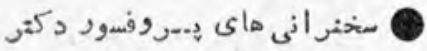

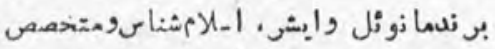

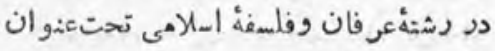

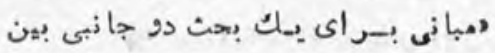

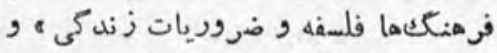

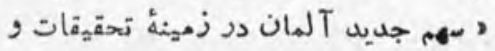

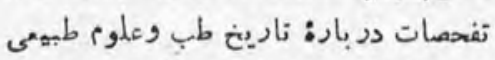

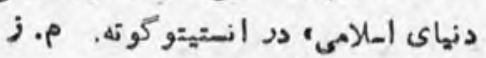

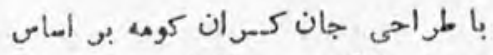

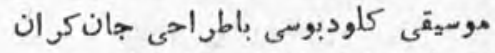
كوولون تارز باطراحى كلنتمليلى بر اساس

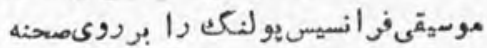

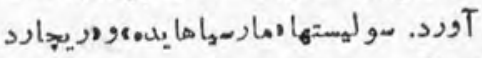

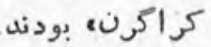

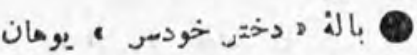

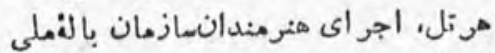

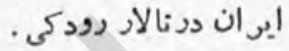

\section{سينما}

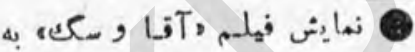

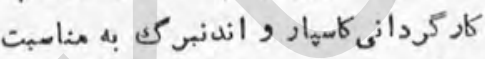

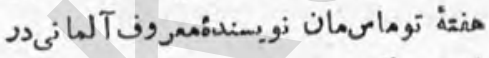
انستيتوكوته تومان.

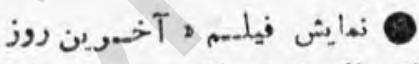

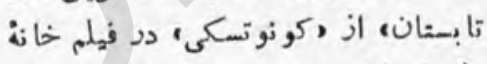
ملى إِران.

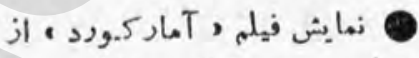

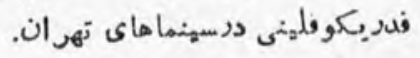

\section{باستان ش-اسسى}

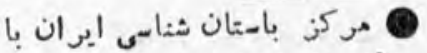

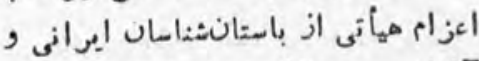

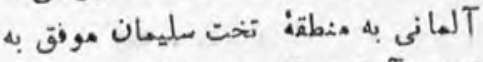

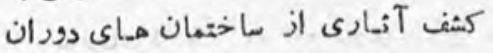

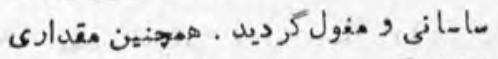

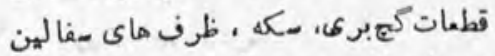
وتهدادى كلشى بدست آورد .

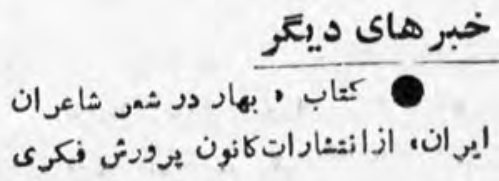




\section{نكاهى به هجولات}

$$
\text { ادوب }
$$

نشرية" سهما هلا يو هنجيى ادبيات وعلوم بشرى يو هن:مونكابل

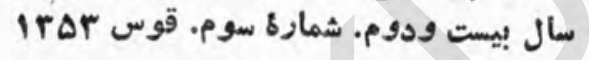

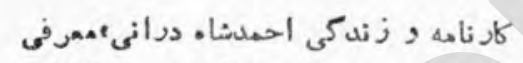

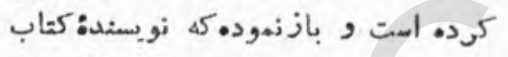

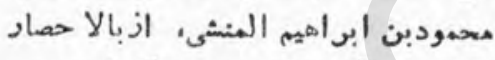

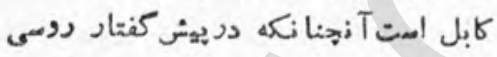

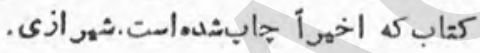

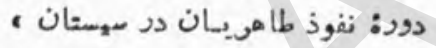
نونتة بوسورث است كه يوهنهلعودا لقهيون

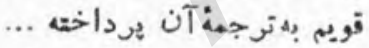

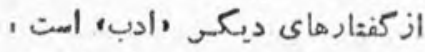

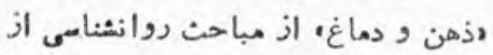

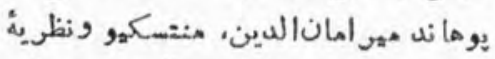

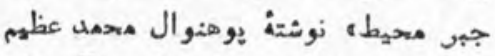

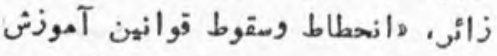

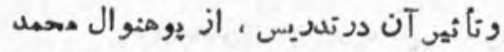

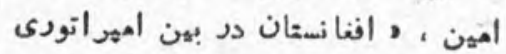

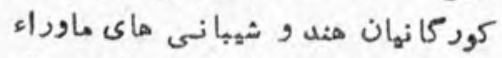

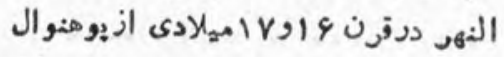

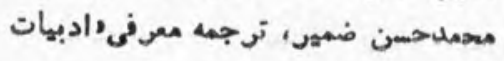

اين دفتر مادب، با كفتار يوهنهل

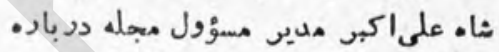
رمولانا جالالالدين بلخي، آغازمىيثود.

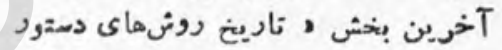
نويسى درزبان درى، نونئه بوها ندالهان

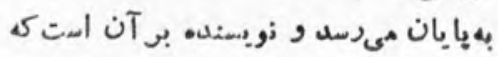

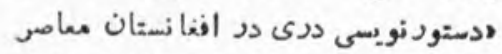

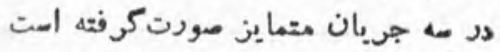

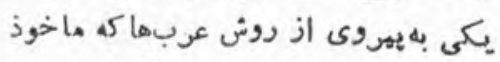

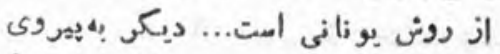

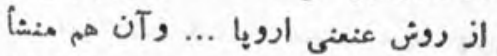

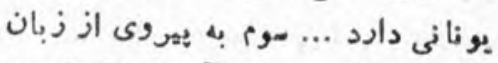

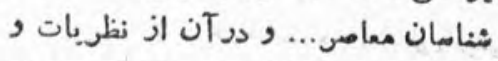
روشهاى بهن الهللى زبسانئاسي الهام

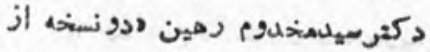

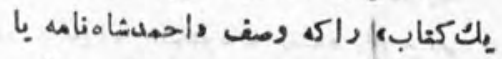

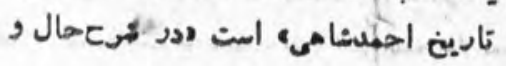




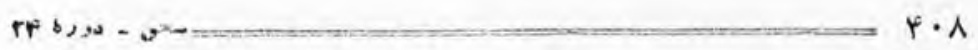

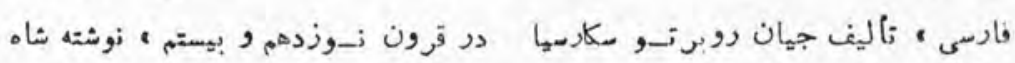

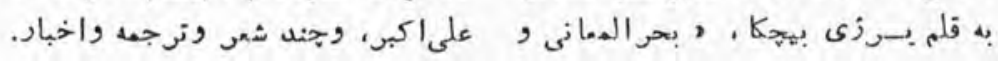

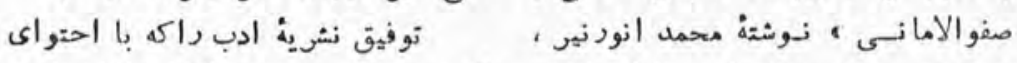

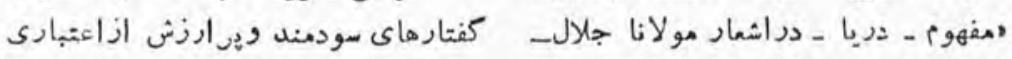

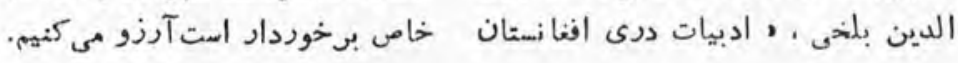

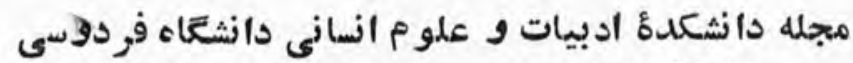
بهيادتار هزاروصدمين سال ولادت ابو نصر فارابى

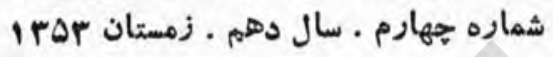

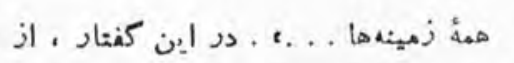

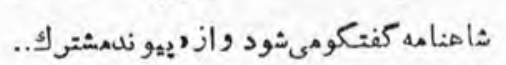

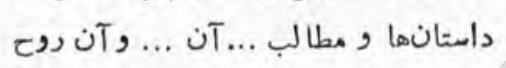
حهاسى .... شاهناهه تأثير كرده و دنكى خاصبه آنها زد...... وز زبان بهمايه وتواناى او....كه

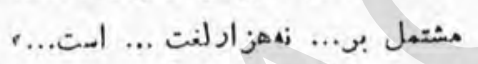

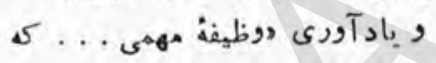
درباسهارى و كسترش زبـان فارسى ...

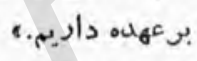

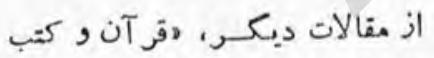
بالاغى ، نوشته محمد علوى مقدم است و بخش دوبم آخـرين ئوهشهاى عبـاس

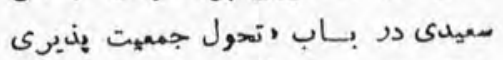
سرخس، و "بيكانكى انسان در ادبيات

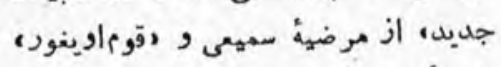

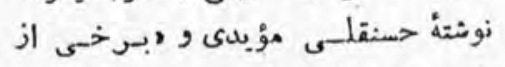

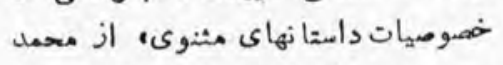

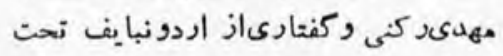
عنوان دهكتوبات جهاهى ، منبعى براى

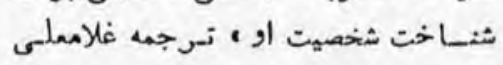

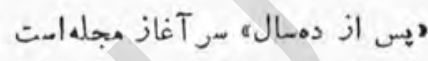
وبهان اهتهاهى كه درر اه تدوبن •rشمار:

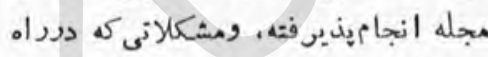

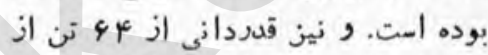

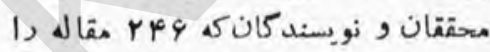
تحريى يا ترجهـ كردهاند.

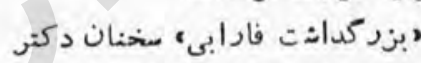
متينى است در مر اسم افتتاع بزر كداثت

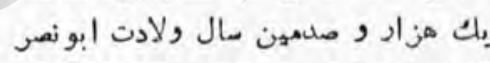

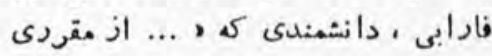

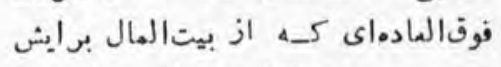

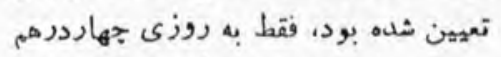

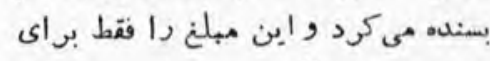

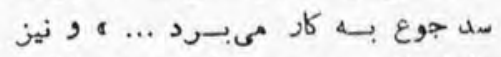

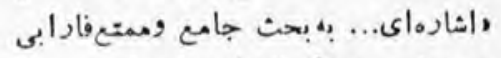
دربارة: , مديثن فاضله و اضلاداد مـدينة فاضله.... دارة متنسخنى انى دكتريوسفى درسومين

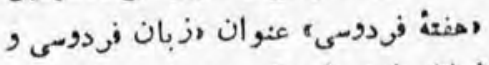

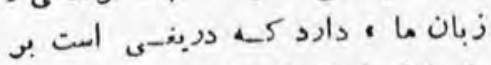

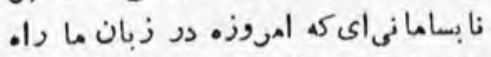

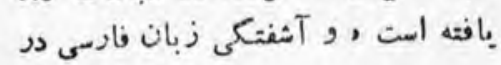




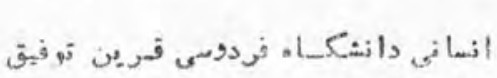

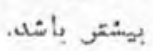

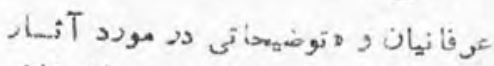

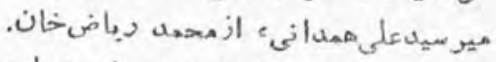

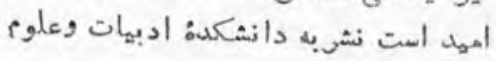

\section{lais.}

سال !يستو هشتم. شماره دوم. اودى بهشت هاه

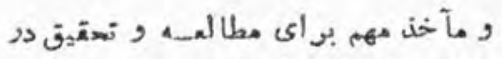

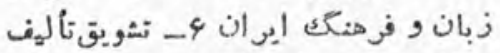
هركونه كتابى كه آهوختن فارسي:صنيح

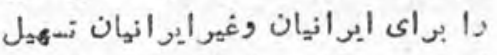

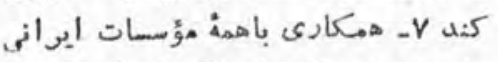

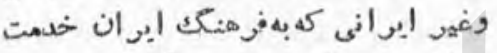

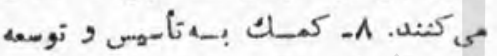

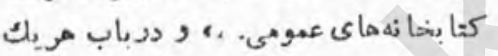

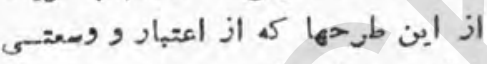

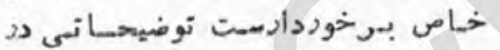
مى افزايد.

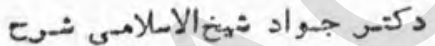

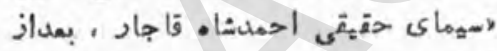

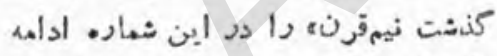

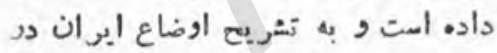

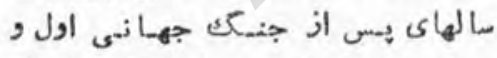
برخوددهاىدوقنزت مسلط روز برايوان

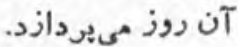
ددربار: اساطس ورواياته كف:هار

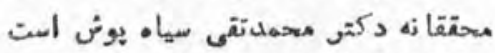

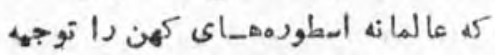

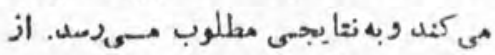

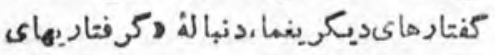

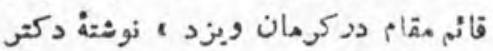

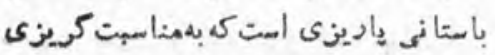

اخخاصراى از كنتار دك: خان نلىى

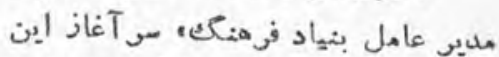

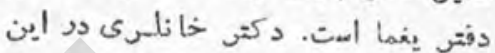

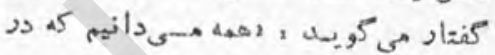

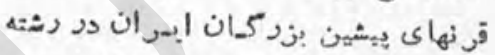

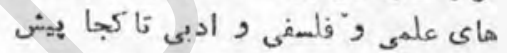

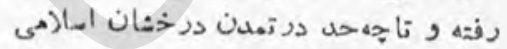
كهموجب إهثرفت دانثي وفرهنك بهشرق

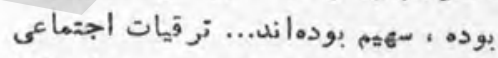
واقتصادى هوجهب رناه و مودد الستفادة:

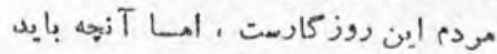

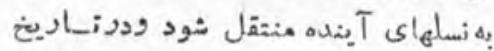

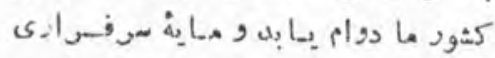

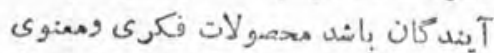

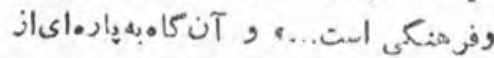

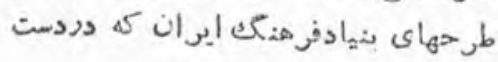

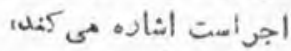

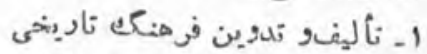

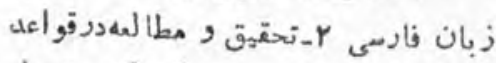
وأصول زبان فارسى و جكو نكسى نجول

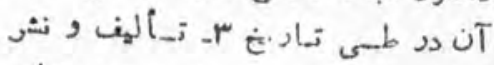

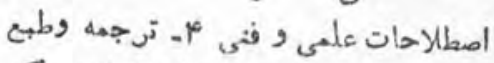

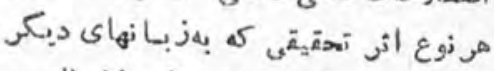

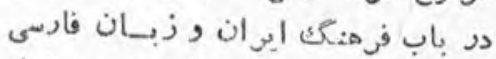
تأليف شده باشه. هـ تهيه اسناد ومهارك 


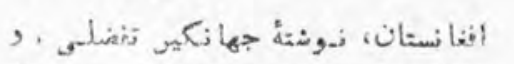

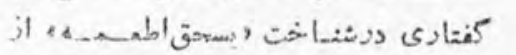

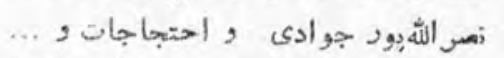

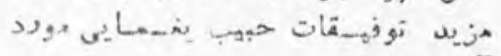

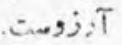

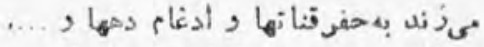

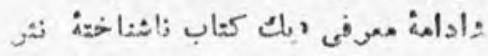

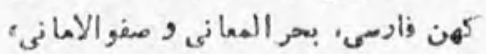

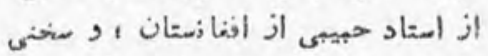

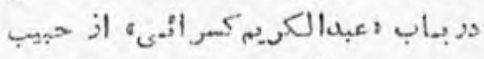

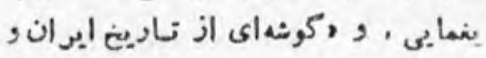

\section{آريا}

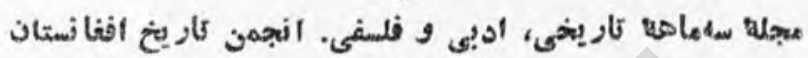

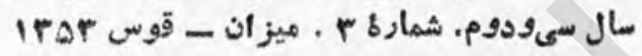

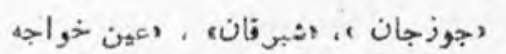

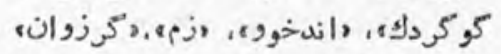

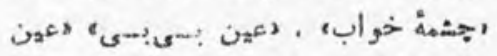

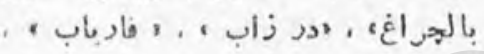

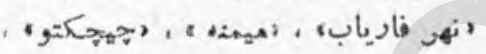

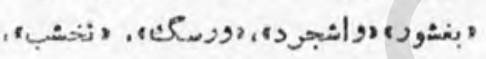

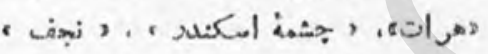

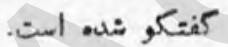

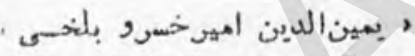

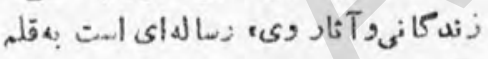

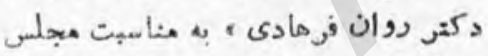

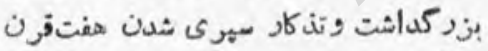

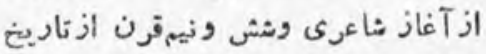

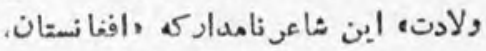

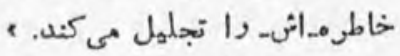

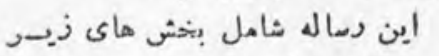

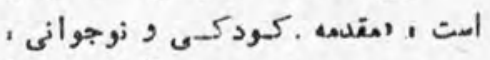

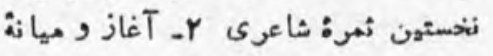

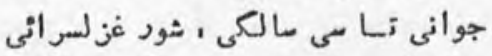

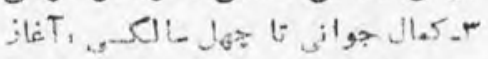
مثنوى نكارى ثا- بايان جوانى و آناز

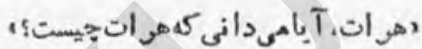

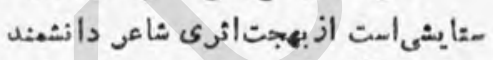

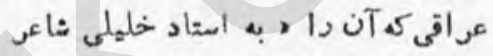

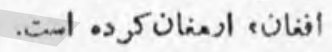

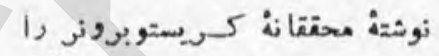

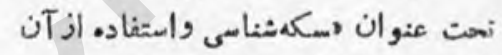
دوتاريخ باستانسى افنا زستان ه السحاق

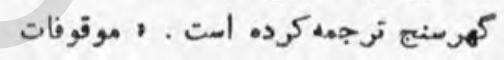

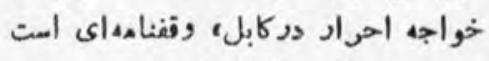

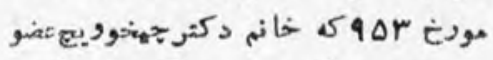

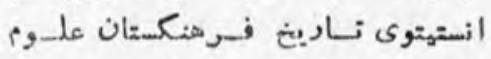

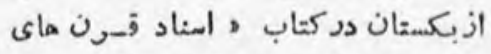

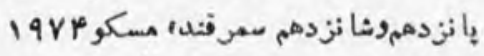
نشركرده الست و إينك در آريا نا منتشر

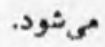
دكتر واحلى حوارجههائى از كتاب بحر الاسراد،را درايندفتر نهز آوردها اند.

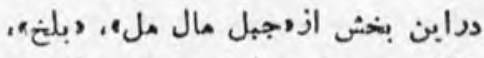

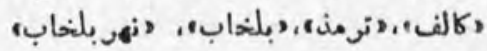

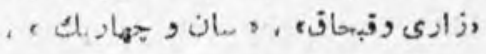

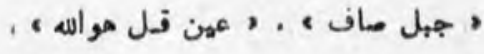


$p \mid 1$ $.4 v^{3}$

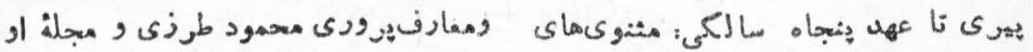

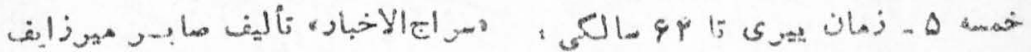

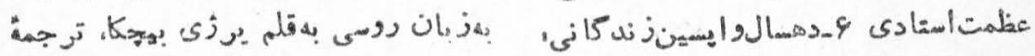

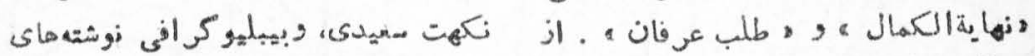

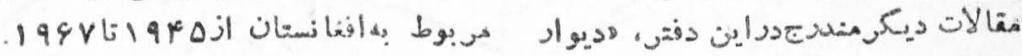

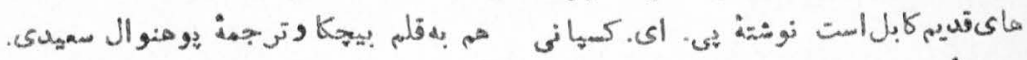

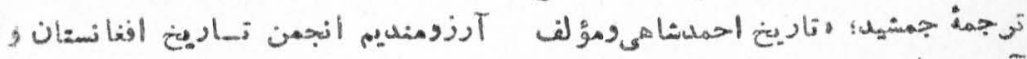

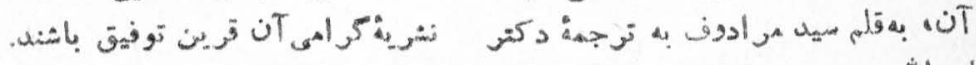
s. P

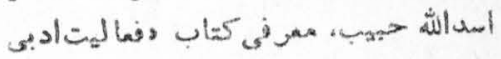




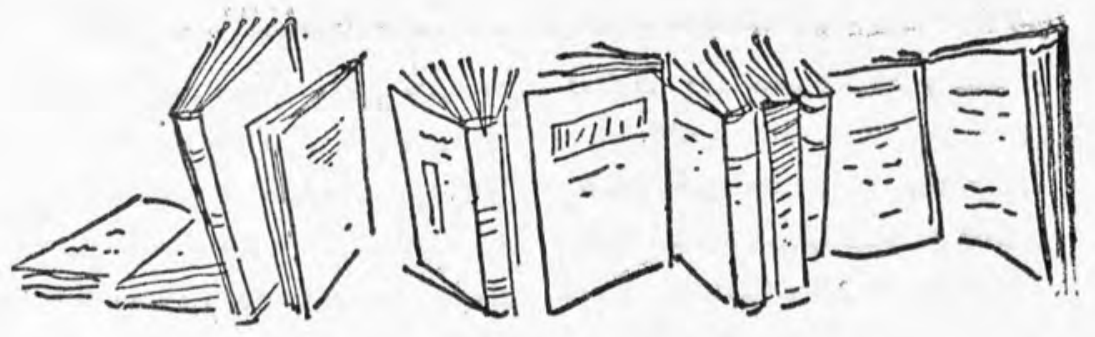

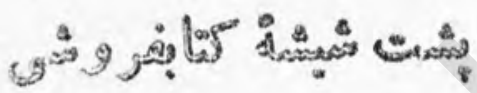

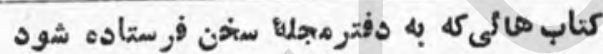

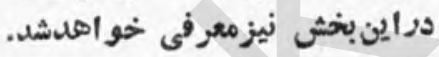

فرهنك الغات مفرده و مر كبه و قواعلى كن ورن جنلك درست كفتن الفاظ دراين لهجه

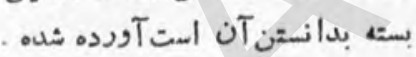

بازى هاى مهحلى فارس

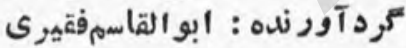

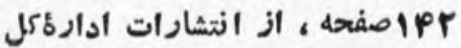
فرهنع وهنر فارس . بازىهاى مجلى كه ساختهويرداخته شرايطوجهات متفاوتاقليمى استهر كمانم

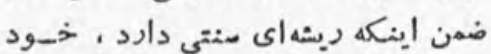

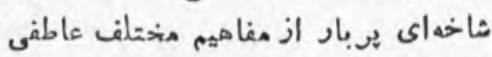

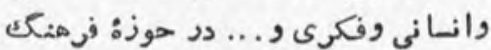

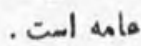
دراينكتاب • بهنوع از اينبازيها

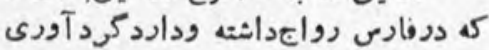
وشرع داده. شده است. رواتدا
نويل دينار در شرح كتاب كان هـالاحت ومثنوى

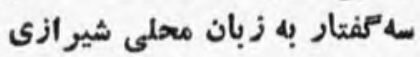

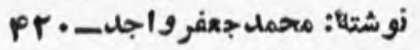

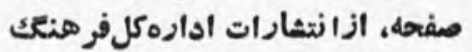
وهنر فارس. ترع وبهانآثار بازما ند:ز بانهاى

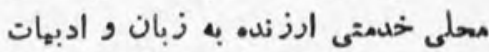

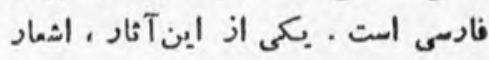

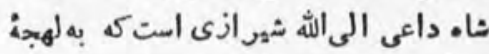

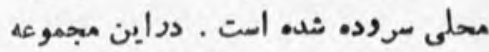

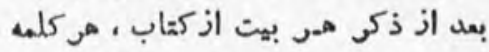

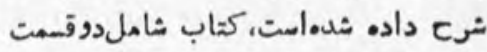
است يكى كتابكان ملاحت ديكرى شرع Aثنوى سه كفتار . در آخح بحثى دربار: توضهدات الفاظ وملا ني مفردات بهمهر ا. 


\section{$p \mid p$}

نفرينها، تقسيم كرديده وشرع داده شند.

l

$$
\text { مرغ حق مان }
$$

مجمهوعه داستان برايكودهان

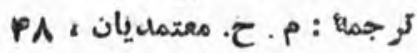

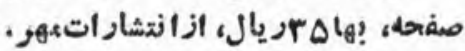

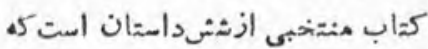

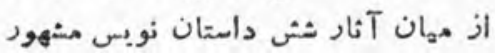
دنيا انتخاب وترجمه شده است آتان.

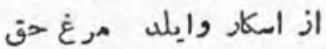

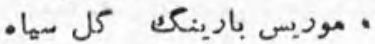

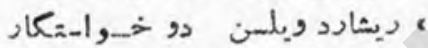
دريكجا

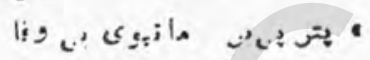

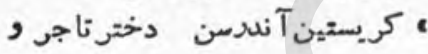
شيرطلسم شده.

، هثرى مكدونالل شاهزاده خانم

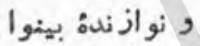

\section{مر ثيه هاى كولى}

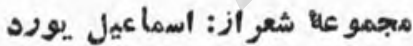

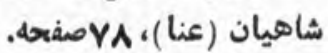

انعارىاست كه بين سالهاى

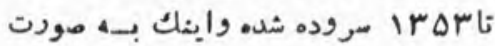

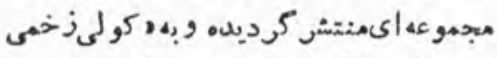
دشتهاى ايلث، تقديمكرده است .

عطر ما آلو شرامعاه

مجموعانً نه قصه

نوشتكا فريله رازى ، بها •و ريال
دو عارف ازكنزون

با همدمهاى در زمينه كازرون درتمنز تاه تار إيخ .

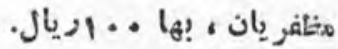

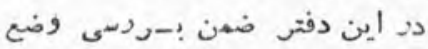

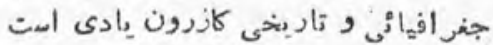

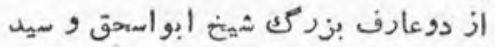

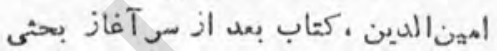
دارد دربار: جغر افياى تاريخى كازئ إنرون

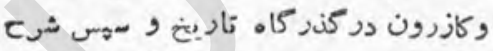

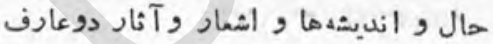

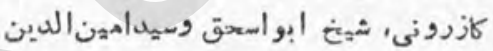

\section{تمو شه هائى ازآداب و رسوم}

$$
\text { مردم شبمراز }
$$

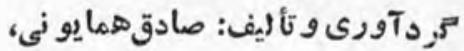
. فر منتك وهنرفارس.

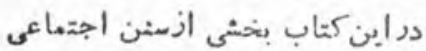

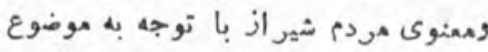

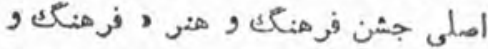
خا نو ادهه كردآورى كرديده استي

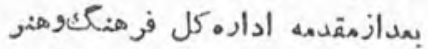

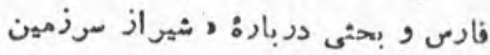

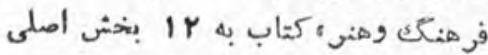

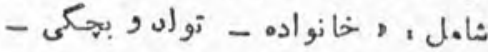

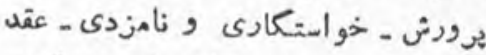

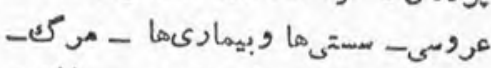

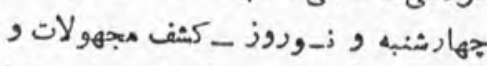

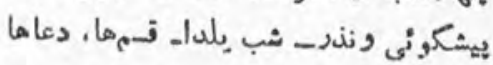




$$
\text { PP PIP }
$$

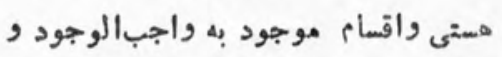

ثمرة شجرة أ أهيه

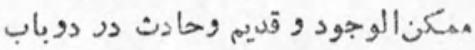

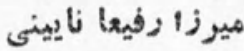

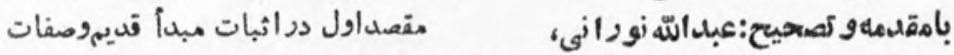

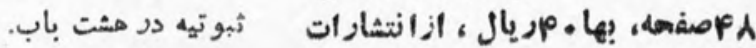

مقصد دوم در صفات سلبيه در جهاد

loف

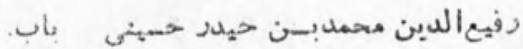

مقصهد سوم درافعال درينتج باب

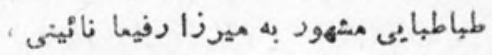

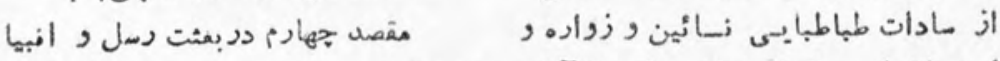

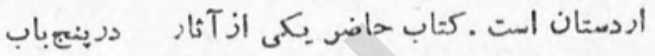

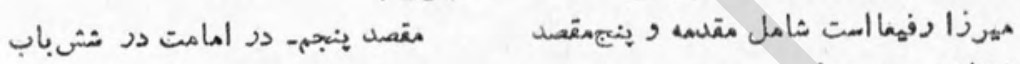

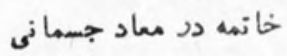

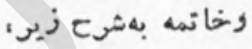

ع. الف. بهشتى.بور

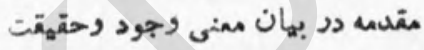




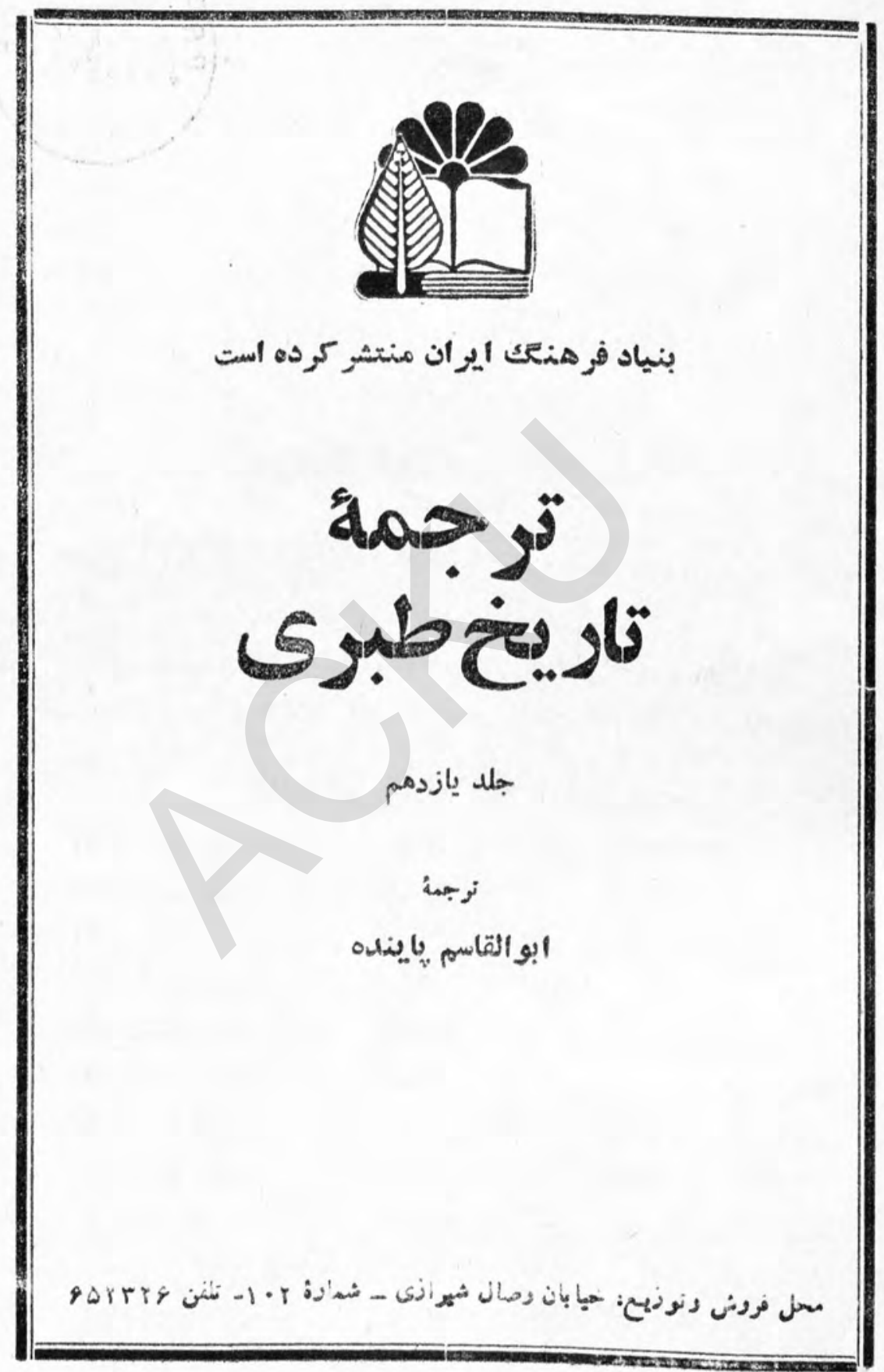




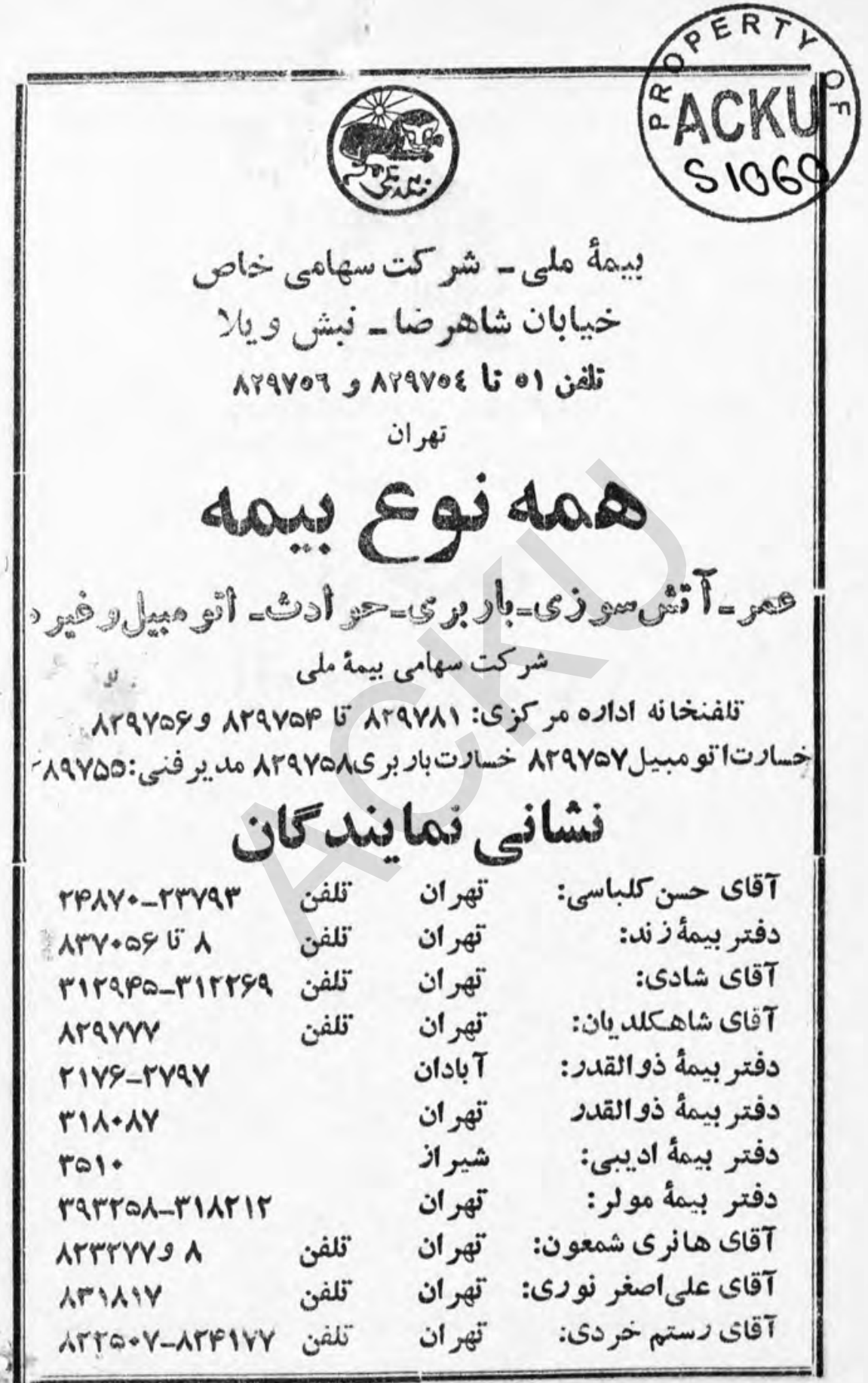




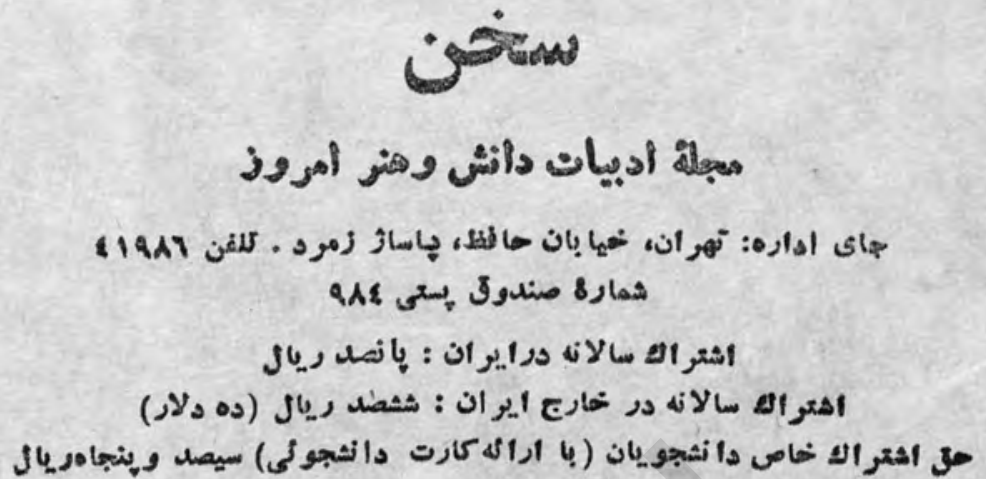

وجهو اشتواك بايل مستقيما به عنوان مجلة سخن بوسيله هياكت

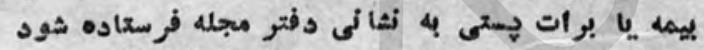

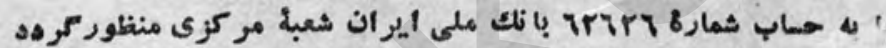

ورسيد آن به وفتر مدجله سخن ارسال شود

صاحب امثياز : دكعريرويز نأو خانلرى

طبع و نقل منلدرجات ومتالات اين مجله ببىاجازه ممنوع است

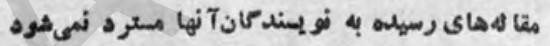

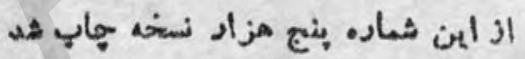

SOKHAN

Revue Mensuelle de Littératuro

et l'Art contemporains

TEHERAN [IRAN]

Abonnement à I'étranger: U. S. \$. 10.00

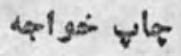

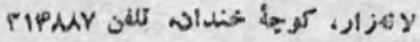




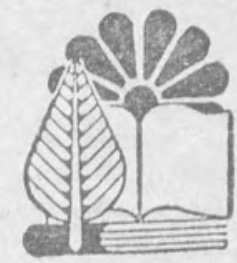

بنياد فرهنع ايران منتثر كردهاست

$$
\begin{aligned}
& \text { "يلى ميان شعر هجائى و عروضى فارسى هرى } \\
& \text { درون }
\end{aligned}
$$

$$
\text { از درجمهاى آهنگين }
$$

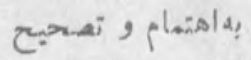

$$
\begin{aligned}
& \text { دكتر احمانعلى رجائى }
\end{aligned}
$$

19. : מ. מ

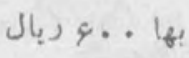

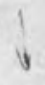

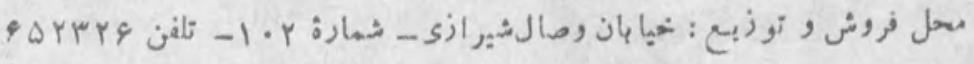

